\title{
Fostering Music Performers in the 21st Century: A Contemporary Professional Perspective toward a New Curricular Agenda for Graduate Study in Music
}

\author{
Andre Januario \\ West Virginia University, aljanuario@mail.wvu.edu
}

Follow this and additional works at: https://researchrepository.wvu.edu/etd

Part of the Advertising and Promotion Management Commons, Art Education Commons, Audio Arts and Acoustics Commons, Cognitive Psychology Commons, Composition Commons, Curriculum and Instruction Commons, Educational Methods Commons, Ethnomusicology Commons, Fine Arts Commons, International and Comparative Education Commons, Liberal Studies Commons, Marketing Commons, Multicultural Psychology Commons, Music Business Commons, Music Education Commons, Musicology Commons, Music Pedagogy Commons, Music Performance Commons, Music Practice Commons, Music Theory Commons, Other Music Commons, Scholarship of Teaching and Learning Commons, University Extension Commons, and the Work, Economy and Organizations Commons

\section{Recommended Citation}

Januario, Andre, "Fostering Music Performers in the 21st Century: A Contemporary Professional Perspective toward a New Curricular Agenda for Graduate Study in Music" (2021). Graduate Theses, Dissertations, and Problem Reports. 10218.

https://researchrepository.wvu.edu/etd/10218

This Dissertation is protected by copyright and/or related rights. It has been brought to you by the The Research Repository @ WVU with permission from the rights-holder(s). You are free to use this Dissertation in any way that is permitted by the copyright and related rights legislation that applies to your use. For other uses you must obtain permission from the rights-holder(s) directly, unless additional rights are indicated by a Creative Commons license in the record and/ or on the work itself. This Dissertation has been accepted for inclusion in WVU Graduate Theses, Dissertations, and Problem Reports collection by an authorized administrator of The Research Repository @ WVU. For more information, please contact researchrepository@mail.wvu.edu. 
Fostering Music Performers in the $21^{\text {st }}$ Century: A Contemporary Professional Perspective toward a New Curricular Agenda for Graduate Study in Music

André Luis da Silva Grützmann Januário

\author{
Dissertation submitted \\ to the College of Creative Arts \\ at West Virginia University \\ in partial fulfillment of the requirements for the degree of
}

Doctor of Musical Arts

in Music Performance

\author{
Lynn Hileman, DMA, Chair \\ Andrew Kohn, PhD, Research Advisor \\ Michael Ibrahim, DMA \\ Mitchell Arnold, DMA \\ Beth Royall, MLIS, MM \\ School of Music \\ Morgantown, West Virginia \\ 2021
}

Keywords: music performance, music curriculum, graduate study in music, music in higher education, music education, classical musicians, $21^{\text {st }}$ century musician, $4^{\text {th }}$ industrial revolution, $21^{\text {st }}$ century

Copyright 2021 André Januário 


\section{ABSTRACT \\ Fostering Music Performers in the $21^{\text {st }}$ Century: A Contemporary Professional Perspective toward a New Curricular Agenda for Graduate Study in Music \\ André Luis da Silva Grützmann Januário}

What if the core curriculum for graduate students in music performance were designed to prepare students to succeed in the world of the Fourth Industrial Revolution?

This dissertation offers a hypothetical answer: a structured and systematic academic curricular framework for music graduate students of performance of concert music (especially those in terminal degrees, such as doctoral students), along with music instructors, professional music performers, school administrators, and college professors, seeking to prepare such students for achieving and maintaining a music career more in keeping with the current work environment, especially those skills demanded by the Fourth Industrial Revolution and the current cultural moment. Syllabi designed by the author for the proposed curriculum are included.

This research is supported by various studies: of the Paris Conservatory, the first state school created during the period of the First Industrial Revolution; of the curriculum of selected outstanding current institutions in the United States; and an analysis of a comprehensive bibliography of recent publications on the topic of the skills needed by current performers of concert music.

The conclusion advocates the development of a new curricular area in music performance: "Professional Musicianship." 


\title{
ABSTRACT \\ (in Portuguese)
}

\section{Fostering Music Performers in the $21^{\text {st }}$ Century: A Contemporary Professional Perspective toward a New Curricular Agenda for Graduate Study in Music ${ }^{1}$}

\author{
André Luis da Silva Grützmann Januário
}

\begin{abstract}
E se o currículo base para estudantes de pós-graduação em performance musical fosse projetado para preparar os alunos para o sucesso no mundo da Quarta Revolução Industrial?
\end{abstract}

Esta tese oferece uma resposta hipotética: uma estrutura curricular acadêmica estruturada e sistemática para alunos de pós-graduação em performance musical, particularmente música de concerto, instrutores de música, músicos profissionais, diretores e coordenadores de escolas de música, e professores universitários, buscando prepará-los para a realização e manutenção de uma carreira musical mais condizente com o ambiente de trabalho atual e, principalmente, as competências exigidas pela Quarta Revolução Industrial e o atual momento cultural. Cursos e programas de estudos elaborados pelo autor estão incluídos neste projeto acadêmico.

Esta pesquisa é apoiada por vários estudos: do Conservatório de Paris, a primeira escola pública criada durante o período da Primeira Revolução Industrial; do currículo de instituições americanas com destaque na área de performance musical; e uma análise de uma bibliografia abrangente de publicações recentes sobre o tema das habilidades necessárias para os atuais intérpretes de música de concerto.

A conclusão deste trabalho defende o desenvolvimento de uma nova área curricular em performance musical: "Professional Musicianship".

\footnotetext{
${ }^{1}$ Este trabalho tem como objeto de estudo primário os currículos de cursos de pós-graduação em música nos Estados Unidos da América e considerou contexto cultural-musical, acadêmico e profissional daquele país. Para a implementação das sugestões curriculares apresentadas neste documento no contexto brasileiro, seria necessário um levantamento de dados bibliográficos em língua portuguesa para a construção de uma literatura que ofereça um arcabouço teórico que possibilite a execução desses cursos na conjuntura acadêmica brasileira.
} 


\section{Acknowledgments}

To West Virginia University and the School of Music, thank you for all the fantastic opportunities.

To my committee, for hours invested in attending my hearings, recitals, comprehensive exams, defense, and the incredible workforce and teamwork to help me conclude this paper, my profound gratitude.

To Dr. Andrew Kohn, my committee research advisor, and theory professor, for sharing his academic and pedagogical experience and guiding me through the writing process, thank you very much. Your classes were always inspiring!

To Dr. Lynn Hileman, my bassoon professor, thank you for your support during my years at WVU.

To Dr. Mitchell Arnold, for all random conversations in his office before (in the middle) and after conducting lessons and rehearsals, thank you very much! I always learned "one or two things" after talking with you. It was a privilege to play under your baton for all these years.

To my conducting professors, Dr. Scott Tobias and Dr. Kym Scott, thank you so much for having me as your teaching assistant and for your outstanding mentorship in these years.

To Professor Beth Royall, thank you for stepping in at the last moment of this project and helping me with remarkable insights.

To all my graduate wind quintet fellows: Angela Reynolds, Evan Klein, Yu-Ting Cheng, Lauren Harding (Harris), Chris Bowmaster, Ramon Thiago, Elaina Lehto, David Stedge, Brianna Corgel, Valanti Marou, and Sarah Plumley. "Hey, guys, start together and finish together. The middle ... we can negotiate." We had beautiful moments together, thank you!

To Lucia Zung, "my partner in crime" in the WVU bassoon section "forever," thank you for sending that email, Lulu! I came, and I graduated! "Melhor, só em Curitiba!"

To my parents and siblings. Thank you for listening to all my "wrong notes." You paved the way to this moment. Aninha and Lininha, thank you for attending my concerts and recitals. You made me feel more confident in those moments.

Last, but definitely not least, thank you for your endless support, my beloved wife, Dr. Letícia Grützmann. "Lindinha," you were the one pushing me all the time during this journey. Thanks for believing in me even when I didn't! "Amo-te a ti!" 


\section{Dedication}

Para o seu Izidoro, dona Ediná, Ana, Aline, Alex, e Letícia.

Os melhores “Januários” da família! 
Table of Contents

ABSTRACT

ABSTRACT (IN PORTUGUESE) III

ACKNOWLEDGMENTS IV

DEDICATION $v$

TABLE OF CONTENTS VI

REFLECTION VII

INTRODUCTION 1

STATEMENT OF TOPIC

PROCEDURE $\quad 5$

$\begin{array}{ll}\text { SECTION I } & 7\end{array}$

$\begin{array}{ll}\text { The Conservatoire de Paris } & 7\end{array}$

The French Revolution and the Pre-Conservatory Period 7

The Advent of the Conservatoire and its Curriculum 10

SECTION II

The “Five Well-Ranked American Music InStitutions” AND their CoRe Curriculums: 13

Preparing Students for the Professional Demands of the 21 ${ }^{\text {st }}$ Century 13

$\begin{array}{lr}\text { The Juilliard School } & 16\end{array}$

$\begin{array}{lr}\text { Berklee College of Music } & 22\end{array}$

$\begin{array}{lr}\text { New England Conservatory } & 23\end{array}$

$\begin{array}{lr}\text { Yale School of Music } & 31\end{array}$

$\begin{array}{lr}\text { Manhattan School of Music } & 33\end{array}$

$\begin{array}{lr}\text { Reflections on the Selected Courses } & 38\end{array}$

$\begin{array}{ll}\text { SECTION III } & 41\end{array}$

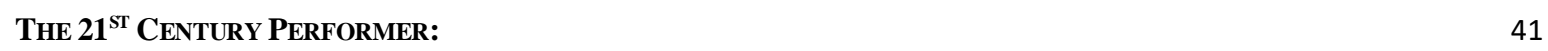

A Contemporary Professional Perspective 41

$\begin{array}{lr}\text { Today's Performer } & 42\end{array}$

$\begin{array}{lr}\text { The Curriculum } & 43\end{array}$

The Proposed Curriculum and its Main Bibliography 46

$\begin{array}{lr}\text { The Curricular Structure and its Contents } & 57\end{array}$

$\begin{array}{lr}\text { Career Development } & 64\end{array}$

$\begin{array}{lr}21^{\text {st }} \text { Century Performance Skills } & 69\end{array}$

$\begin{array}{lr}\text { CONCLUSION } & 74\end{array}$

$\begin{array}{ll}\text { BIBLIOGRAPHY } & 76\end{array}$

$\begin{array}{lr}\text { APPENDIX A } & 83\end{array}$

$\begin{array}{lr}\text { SAMPLE SYLLABI } & 83\end{array}$

$\begin{array}{lr}\text { Career Development } & 83\end{array}$

$21^{\text {st }}$ Century Performance Skills $\quad 94$

$\begin{array}{lr}\text { APPENDIX B } & 104\end{array}$

$\begin{array}{ll}\text { Core Curricula from the institutions included in this paper } & 104\end{array}$

$\begin{array}{lr}\text { APPENDIX C } & 110\end{array}$

$\begin{array}{lr}\text { APPENDIX D } & 115\end{array}$

$\begin{array}{lr}\text { COURSES INCLUDED IN THIS STUDY } & 115\end{array}$

$\begin{array}{lr}\text { BIO } & 117\end{array}$ 


\section{Reflection}

To arrive at the edge of the world's knowledge, seek out the most complex and sophisticated minds, put them in a room together, and have them ask each other the questions they are asking themselves.

James Lee Byars 


\section{Introduction}

As performing musicians, especially those that perform concert music, we tend to reproduce, either consciously or subconsciously, methodological processes that were established before the Fourth Revolution. ${ }^{2}$ Since the advent of the Fourth Revolution, which characterizes the $21^{\text {st }}$ century, artists have to adapt to this new era by incorporating new methodologies, approaches, mindsets, and technologies into their learning, teaching, and how they perform.

The necessity of incorporating new subjects has not gone unnoticed, and we can observe a substantial awareness of this matter among scholars and music performers. The topics, methodologies, approaches, and technologies suggested here include performance anxiety knowledge, brain mechanism, environmental influences, apps, social media skills, music psychology, and other skills associated with the "Information Age" such as critical thinking, creativity, collaboration, communication, information literacy, media literacy, technology literacy, flexibility, leadership, initiative, productivity, and social skills.

For the most part, the need for these skills is not new. However, the new demands created by the Fourth Industrial Revolution has made it urgent that they be addressed directly and vigorously. Certainly, experienced music performers and instructors already address these concerns in their teaching methodologies and performances, and some music institutions have adopted these concepts and contents as part of their curricula. However, two issues must be faced. First, students are dependent upon good fortune if they are to work with

\footnotetext{
${ }^{2}$ The First Revolution (or First Industrial Revolution) occurred in the $18^{\text {th }}$ century. Mechanization, steam, and waterpower were the "motor" and impulse which marked this period. The Second Revolution brought electric power and mass production. The Third Revolution used electronics and information technology to automate production. Now, the Fourth Industrial Revolution brings the digital revolution. It has been occurring since the middle of the last century. It is characterized by a fusion of technologies that is blurring the lines between the physical, digital, and biological spheres.
} 
an instructor interested in these concepts and skills; they are far from universally taught. This is reflected at an institutional level as well: few schools of music incorporate these matters into the institution's curriculum, and if they are included, it is often only as an elective. The second issue is due to the structural characteristics of higher education institutions and academia itself. When compared to the industrial environment, academia is slow to embrace social movements and their cultural agenda. Before the academy adds new contents to a curriculum, it undergoes a careful and time-consuming process of scrutiny, analysis and review, coupled with questions of feasibility. Consequently, students are often unable to be exposed to the most recent topics and technologies during their academic journey.

What if it were possible to design a core curriculum for graduate study in the performance of concert music that prepared the graduate student for the current work environment, one precipitated by the Fourth Industrial Revolution? What would that look like?

This document addresses these questions by offering a structured and systematic academic curricular guide for music performance graduate students (especially those in terminal degrees, such as doctoral students). As such, it intends to provide useful resources for those who educate such students: that is, music instructors, professional music performers, school administrators, and college professors, all of whom have an interest in preparing the aspiring professional to achieve and maintain a music performance career in the $21^{\text {st }}$ century context.

The scope of this project does not extend to all advanced musical studies. To narrow its scope, this dissertation concentrates its research on a particular music field, in this case, music performance, with emphasis on the academic preparation of graduate students in music performance, focusing on "classical" musicians and the concert music genre. 
To develop this research, the document has reflected on the current pedagogical and professional context, pondering possible implications of keeping the same modus operandi from the past and how the $21^{\text {st }}$ century's cultural moment can influence our musical training and profession. A valuable starting point would be to assess how the training of advanced professional performers of concert music has changed since its origins. As part of this reflection process, the author analyzed the foundation of the Conservatoire de Paris, the first state school created during the period of the First Industrial Revolution, and its initial curricular structure. This is compared with how the graduate music performance core curriculum has been organized in the United States. This topic is focused by a close examination of how five American higher education music institutions - ones focused on music performance training — have maintained or modified their curriculum, with special attention to how they have addressed musical subjects and designed courses that are specific to preparing musicians living in the fourth revolution - that is, in the third decade of the $21^{\text {st }}$ century. What has been retained since the founding of the Paris Conservatoire? What changes have arisen within the digital era?

The comparison of the period following the French Revolution to the present day has benefits that might seem surprising. During this project's initial data collection process, the author of this paper realized that both historical periods, which coincide with the first and the fourth industrial revolutions, share cultural and social similarities, ones specific to how a performing musician of concert music makes a living. These similitudes between the familiar and the new might help the readers forge bonds with the ongoing technological and sociological processes in this third decade of the 21 st century.

The document has taken two procedures to investigate the music performance core curriculum in the U.S. and the five American music institutions. The first action was to investigate American schools recognized worldwide as providing excellent music 
performance training. The specific topic is the analysis of the courses offered by those institutions, including required and elective classes. The second action was to examine the National Association of Schools of Music handbook 2020-2021, its requirements and expectations for graduate studies in music performance in the U.S.

A topic central to this document is core curriculum, which therefore requires a careful definition. This paper defines it as the body of knowledge expected to be learned by all students, generally related to a set of subjects and learning areas that are common to all students in a major. In the scope of this study, considering the NASM requirements ${ }^{3}$, a typical core curriculum for graduate study in music in the U.S., besides the major specialization, comprises music theory (or analysis), musicology, and bibliography and research courses.

As a result of this investigation, it appears that the core curriculum for graduate students in music performance in the $21^{\text {st }}$ century could fruitfully embrace some subjects and a set of skills demanded by the fourth industrial revolution and the current cultural moment.

This information must be compared with a body of knowledge currently available and relevant to aspiring performers of concert music living in the world of the fourth revolution. This document includes and analyzes a substantial bibliography and additional materials. On this basis, this author designed courses, along with syllabi, that might contribute to the current professional and pedagogical landscape in the U.S. and, indeed, worldwide.

\footnotetext{
${ }^{3}$ NASM: National Association of Schools of Music. This organization will be presented and further discussed in Section III.
} 


\section{Statement of Topic}

\section{The purpose of this study is:}

- to contribute to the ongoing research into and development of possible new areas of study in music, especially the search for a comprehensive and holistic curriculum;

- to offer a guide for graduate students specializing in concert music performance (especially those in terminal degrees, such as doctoral students), along with music instructors, professional music performers, school administrators, and college professors seeking to prepare such students for achieving and maintaining a music career more in tune with the current work environment. ${ }^{4}$

\section{Procedure}

This study was divided into the following sections (along with appendixes):

\section{Section I - The Conservatoire de Paris}

To understand the evolution of the music performance studies and how a historical context can influence this process, this document uses as a milestone the foundation of the first governmental institution to offer universal access to young people to obtain free music training, the Conservatoire de Paris. This section examines its origins, historical context, and first core curriculum to comprehend the impact of this conservatory in the music performance field in its origins. This part of the research aims to offer the reader an overview of how the "conservatory model" shaped and standardized music teaching and training after its foundation and its curricular reverberations in the current classical musician's training.

\footnotetext{
${ }^{4}$ While this document is broadly applicable, it uses the terms "musician," "performer," and "artists," to refer to those who specialize in the performance of concert music; these are the musicians of special focus here.
} 


\section{Section II - The "Five Well-Ranked American Institutions" and Their Curriculums: Preparing Students for the Professional Demands of the $21^{\text {st }}$ Century.}

After becoming familiar with the Conservatoire history, the second section of this document analyzes the core curriculum and electives classes and its course descriptions of the Five Well-Ranked American Higher Education Institutions according to Kushwaha's article. ${ }^{5}$ This section explores the topics considered non-canonical ${ }^{6}$ and reflects on why these schools are working on those contents to provide holistic music training to their music performance students. This portion of the document offers a catalog with the course descriptions provided by these schools. It concludes the analysis by providing a percentage chart of which courses and subjects the selected institutions have created, developed, or adapted to address today's professional demands.

\section{Section III - The 21 ${ }^{\text {st }}$-Century Performer: A Contemporary Professional Perspective}

In the third and final segment of this dissertation, the author poses some reflections on the implications of keeping the same modus operandi from the past, its consequences, and how the new century can influence our music training and profession. This section investigates the skills demanded by the professional field for the $21^{\text {st }}$-century performer. How should the $21^{\text {st }}$-century musician approach this new era and its complexity? What skills should musicians know or develop according to the current scenario? Where should we learn this new set of skills?

To provide a well-rounded and supported answer to the inquiries raised in this portion, the document selected and reviewed books, articles, and additional materials, besides

\footnotetext{
5 "Best Music Schools in The World For 2019." CEOWORLD Magazine. March 23, 2019. Accessed April 04, 2019. https://ceoworld.biz/2019/03/23/best-music-schools-in-the-world-for-2019/. This article will be further discussed in Section II.

${ }^{6}$ Further description of the term "non-canonical" will be explained in the following pages.
} 
the online material provided by the institutions investigated in Section 2. Based on these resources, the author has designed courses and sample syllabi. The author also suggests curricular alternatives to equip music performance graduate students, music instructors, professional music performers, school administrators, and college professors with pedagogical options that envision a way to offer tools that will prepare them for the $21^{\text {st }}$ century professional demands.

\section{Section I \\ The Conservatoire de Paris}

\section{The French Revolution and the Pre-Conservatory Period}

Established on August $3^{\text {rd }}$, 1795, the Paris Conservatory is one of France's most prestigious musical institutions. ${ }^{7}$ Among its several attributes, the Conservatoire, as it is called in France, is recognized as one of the world's first governmental institutions that offered universal access to young people to obtain free music training. It is not a coincidence that the Conservatoire and what is known as the "Directory" period started in the same year. The new government's agenda, led by the Girondins, wanted to obliterate the previous period, led by Robespierre and the Jacobins, a period historically known as "The Reign of Terror."

The social and artistic role of the Conservatoire was intimately connected to the new administration's change of direction proposed by the Directory. This new political period buried the reign of terror. In fact, the establishment of the Conservatoire was part of a comprehensive reform of the whole educational system in the country, from higher education

\footnotetext{
7 To narrow and establish many analyzable sources in this section, only those articles published in the last five years shall be used. For books, only those published during the previous ten years are considered. The material used includes: Kailan R. Rubinoff, "Toward a Revolutionary Model of Music Pedagogy: The Paris Conservatoire, Hugot and Wunderlich's Méthode de flute, and the Disciplining of the Musician" (2017); D. Kern Holoman, "The Paris Conservatoire in the Nineteenth Century," (2015); and Frédéric de La Grandville, Une histoire du piano: au Conservatoire de Musique de Paris - 1795-1850, (2014). The latter was used to describe the context of the Paris Conservatoire foundation, its system, and its core curriculum in 1795.
} 
to general primary education, after the French Revolution began in 1789. Prior to the

Revolution, artistic and scientific institutions such as the Royal Academy of Painting and

Sculpture, the French Academy, and the Academy of Sciences were considered related to the Ancien Régime, the monarchy. The revolutionaries perceived these institutions as elitist, and many of them argued strongly for these organizations' dismantlement. Thus, in 1793, these institutions were abolished and replaced by national institutes. ${ }^{8}$

After establishing the national institutes, the government's second concern with respect to the educational system was standardization. For centuries, the Catholic Church developed a central role in the educational structure in France. Following the revolution, Church and state were officially separated, and the government had new political and philosophical intentions: to create an educational system in consonance with republican ideals.

Standardized curriculums and teaching methods were designed to accommodate the four fundamental republican values: secularization, democratization, anti-monarchism, and centralization. This meant that all children would be considered equals under the new regime, with no social and economic distinction and free access to education. In addition to these four general goals, there was one more specifically musical concern that the new government was

\footnotetext{
${ }^{8}$ The lack of consistency related to the nomenclature of some institutions might lead to a misunderstanding. For instance, despite the abolishment of organs related to the crown, Frédéric de la Grandville's book indicates that École Royal de Chant (Royal Singing School) kept its activities until the establishment of the Paris Conservatoire, in 1795. However, Kailan Rubinoff's article states that this school was renamed the Institut National de Chant and Déclamation in 1793 and went extinct in 1795 with the establishment of the Conservatoire. Interestingly, the Portail National de Archives (French National Archives) registers the following nomenclatures and years for these institutions:

École royale de chant (Paris ; 1784-1795)

Conservatoire de musique (Paris ; 1795-1806)

Conservatoire de musique et de déclamation (Paris ; 1806-1946).

Since the latter source is an official portal of the French government, this paper will follow the nomenclatures adopted by the French National Archives on this matter.

https://francearchives.fr/findingaid/8a77efe56f363ff63cc72c927c4fe1d2961cb088\#
} 
focused on solving: how to supply the recently created Corps de Musique de la Garde

Nationale with top-quality military musicians.

On June 9, 1792, Bernard Sarrete, a National Guard captain who organized the guard's musicians in 1789 to celebrate the Revolution and who led the musicians during the Fédération, ${ }^{9}$ was authorized by the Conseil Genéral de la Commune to create the École de Musique de la Garde National. ${ }^{10}$ This school was to offer free music instruction to the military's sons from the sixty National Guard battalions.

The following criteria were adopted to organize the entrance exam: candidates with no music training should be between 10 to 16 years old. Candidates who were already musicians should be between 18 to 20 years old. ${ }^{11}$ The students were admitted after an entrance exam evaluated by a jury formed by a maître de musique and assisted by a professeur de chaque instrument. ${ }^{12}$

One hundred twenty students were admitted (including only those woodwind and brass instruments essential to military bands). According to Constant Pierre, ${ }^{13}$ the curriculum was designed to offer two solfege lessons and three instrument lessons per week. In 1793, the Institut National de Musique was created, paving the path to the merging of the École Royal de Chant $^{14}$ and the Institut National de Musique.

\footnotetext{
${ }^{9}$ Fête de la Fédération: The celebration of the first anniversary of the storming of the Bastille, on July 14, 1790.

${ }^{10}$ Frédéric de La Grandville, Une Histoire Du Piano Au Conservatoire De Musique De Paris, uses the nomenclature École de Musique de la Garde National when refering to the institution. However, Kailan Rubinoff refers to this institution as École Gratuite de Musique de la Garde National Parisienne (Free School of Music of the Paris National Guard). It is unclear the reason for this discrepancy related to the name of this school.

11 The sources consulted during the elaboration of this paper did not provide the reasons for such criteria.

${ }^{12}$ Constant Pierre : Bernard Sarrette et les origines du Conservatoire National de Musique et de Déclamation, Paris, Delalain, 1895, Appendix Section, Règlement pour École gratuite de Musique de la Garde Nationale, page 178, item I. https://archive.org/details/BSG_8QSUP670/page/n191/mode/2up

13 Constant Pierre : Bernard Sarrette et les origines du Conservatoire National de Musique et de Déclamation, Paris, Delalain, 1895, Appendix Section, Règlement pour École gratuite de Musique de la Garde Nationale, page 178, item II. https://archive.org/details/BSG_8QSUP670/page/n191/mode/2up

14 According to Grandville, the École Royal de Chant was founded in 1784 and directed by François Joseph Gossec until the establishment of the Conservatoire. It was created to foster and provide singers to work at L'Opéra de Paris and to serve the King in Royal events. Its curriculum consisted primarily in voice studies and
} 


\section{The Advent of the Conservatoire and its Curriculum}

Whereas many Catholic institutions in France held choirs in their primary schools, these vocal ensembles were open only for boys. Their main goal was to foster choirboys for the Church. The government's new plan was impressively progressive in different perspectives. When the Conservatoire was established, the principle of the égalité was applied. According to the bill that established the Conservatoire, the school should be open to boys and girls and proportionally accept students from each French department. ${ }^{15}$

It was necessary to develop systematic methodologies to guide the professeurs into this new system and ensure that all students would receive the same music training. At this point, we notice the strong influence of militarism in the Conservatoire organization and in its pedagogical structure. Bernard Sarrete, (newly retitled as the Paris's Conservatoire first director) developed a rigid teaching philosophy based on military discipline and stages.

Unlike the guilds, confraternities, métiers, and other corporations that were based on the master-apprentice relationship, the Conservatoire elevated the teaching system to a new pedagogical approach. Now, a standardized system intended to offer all citizens the same opportunity to be musically (and professionally) educated.

\footnotetext{
scene. Other disciplines were offered to give a solid cultural background to the students such as: history, mythology, French language, geography, dance, and weapons.

${ }^{15}$ Département: largest unit of local government in France and in some former French colonies.

The départements were originally created in 1790. Each département is governed by an elected general council, which holds responsibility for local services, laws, and budget; an officer called a commissioner represents the national government and is the council's executive agent. Prior to the French Revolution the local unit in France was the military gouvernement, which roughly corresponded to the old provinces, such as Franche Comté, Provence, Bourgogne, Bretagne, and so on. But by the time of the French Revolution this division seemed too closely bound up with the administrative mismanagement of the ancien régime, and, at the suggestion of the Count de Mirabeau, the "provinces" were divided into départements, which were roughly equal to a certain average of size and population and which derived their names principally from rivers, mountains, or other prominent geographic features. Britannica, T. Editors of Encyclopaedia. "département." Encyclopedia Britannica, July 20, 1998. https://www.britannica.com/topic/departement.
} 
We see that the Paris Conservatoire curriculum was highly ordered; moreover, it had a hierarchical structure. ${ }^{17}$ According to Rubinoff, "initially, the Paris Conservatoire structured its curriculum in three orderly stages or degrees. In the first degree, students were educated in solfège and the principles of music; once admitted to the second degree, they received instruction in singing and in their chosen instrument; in the third degree, they received instruction in the theory and history of music, accompaniment, and advanced lessons on their instrument. ${ }^{18}$ "

Students were supervised by teachers, who in turn reported to five inspecteurscompositeurs (inspector-composers) charged with planning the process of musical skill acquisition and standardizing repertoire: These inspecteurs-compositeurs themselves reported to the director (Sarrette), the institution's state representative.

The Conservatoire's charter required that the inspector-composers be explicitly chosen from the composition faculty. ${ }^{19}$ The head professor developed the Conservatoire's pedagogical material in each subject and evaluated it by a committee. Professeurs could only use the method books and texts officially approved by the committee. Thus, the pedagogical committee could make sure that there would be consistency across disciplines. ${ }^{20}$

The establishment of the Conservatoire is one of the many consequences of the foundation of the Modern Era; it also brought about its own consequences. After centuries of individualized training and exclusionary access to education led by guilds, confraternities, métiers, and other corporations that were based on the master-apprentice relationship, the

\footnotetext{
${ }^{17}$ Kailan Rubinoff, “Revolutionizing Nineteenth-Century Flute Technique: Hugot-Wunderlich's Méthode de Flûte (1804): Part I." Traverso Historical Flute Newsletter 22, no. 1 (March 2010): p.3.

${ }^{18}$ Kailan Rubinoff, "Revolutionizing Nineteenth-Century Flute Technique: Hugot-Wunderlich's Méthode de Flûte (1804): Part I." Traverso Historical Flute Newsletter 22, no. 1 (March 2010): p.3.

${ }^{19}$ Kailan Rubinoff, "Revolutionizing Nineteenth-Century Flute Technique: Hugot-Wunderlich's Méthode de Flûte (1804): Part I." Traverso Historical Flute Newsletter 22, no. 1 (March 2010): p.3.

${ }^{20}$ Kailan Rubinoff, "Toward a Revolutionary Model of Music Pedagogy: The Paris Conservatoire, Hugot and Wunderlich's Méthode De Flûte, and the Disciplining of the Musician.” The Journal of Musicology 34, no. 4 (2017): 473-514: p. 490.
} 
idea of a large institution, organized and regulated by the state, providing formal and professional music training seems to have brought new perspectives on the music career. A professional musician held a specific set of skills, regulated and inculcated by the Conservatoire.

Furthermore, and drawing closer to the central topic of this study, we can find similarities in the way the faculty of the Conservatoire understood and structured their core curriculum then, and how the music core curriculum is still conceived today: studies in music theory, music history, and especially the performance of music, rooted in solfège.

This contextualized overview of the initial history of the Paris Conservatory aims to help the reader to understand the role of the conservatories and schools of music then and now: to offer technical training to fulfill the current professional demands. The reader will observe more closely in the followings sections, that currently, following the initial model of the Conservatoire, modern pedagogical institutions - including both independent conservatories and schools of music that function within larger institutions such as Universities - use what are arguably anachronistic pedagogical models that rely on curricular structures and courses that might not actually offer their students the skills and knowledge necessary for professional success in the $21^{\text {st }}$ century. We will further investigate this matter and possible solutions for it in section III. 


\section{Section II}

\section{The "Five Well-Ranked American Music Institutions" and their Core Curriculums: Preparing Students for the Professional Demands of the $21^{\text {st }}$ Century}

As observed in the previous section, the Conservatoire and its predecessor institutions offered a music curriculum focused on three pillars: music theory, music history, and instrumental lessons. Similar to music institutions in France in the $18^{\text {th }}$ and $19^{\text {th }}$ centuries, the purpose of the current higher education institutions (a priori) remains as it was: to teach and prepare music students to fulfill their duties as professional musicians. Interestingly, two hundred and twenty-five years after the Conservatoire establishment, today's music core curriculum' appears to retain in large measure a similar structure. ${ }^{21}$

It is important to emphasize "core curriculum" because of the noticeable efforts made by higher education institutions, which shall be examined through a focused study of five exemplars, to offer their students opportunities broaden their musical and professional scope, including specific course offerings.

After analyzing the core curriculum of these five higher education music institutions in the United States, we see that few structural changes have occurred in these institutions' music performance core graduate curricula; other topics remain peripheral, even optional. True, we can observe some emphasis on certain subjects of increased current interest, such as gender or career. Nevertheless, these topics rarely stand forth as courses that are selfsufficient and required: in some institutions, these subjects have been amalgamated with other classes, such as musicology, while in other schools, these subjects are offered as elective classes.

\footnotetext{
${ }^{21}$ See Appendix A - Core Curricula of the five institutions analyzed in this paper.
} 
We now investigate which courses and subjects the institutions have created or redesigned to address the demands of the current work environment. Due to the vast number of higher education music institutions in the U.S., it is impracticable for a dissertation document to analyze all curriculums in graduate music performance. Instead, we shall examine five programs, a manageable number of what have been called "best institutions." The notion of a "best institution" is admittedly a vexed one, and any professional might prefer a different list. However, the criteria most fervently to be avoided would be to rely on personal preference and the vagaries of an individual's professional experiences. A more defensible position would be an external evaluation based on academic protocols, with consistent metrics and a high degree of reliability.

Rank lists abound, and numerous were analyzed and considered. These include websites, college career magazines, music magazines, and professional musicians' blogs focused on a music career. This document relies on the rank list provided by Ayushi Kushwaha. ${ }^{22}$ Kushwaha was chosen for the breadth and transparency of her methodology. Kushwaha based her analysis on six major indicators of quality; the overall score (out of $100 \%)$ is the sum of:

22 "Best Music Schools in The World For 2019." CEOWORLD Magazine. March 23, 2019. Accessed April 04, 2019. https://ceoworld.biz/2019/03/23/best-music-schools-in-the-world-for-2019/. The rankings are the result of a rigorous analytical exercise, incorporating multiple data sources, without relying on university data submissions.

- Detailed survey data and information collected directly from 45,000 individuals, across 6 data points.

- Surveys completed by 20,000 students and 25,000 industry professionals around the world.

- Magazine surveyed 45,000 people in 42 countries between December 2018 and 20th February 2019. The margin of sampling error for the full sample of 45,000 respondents is plus or minus 1.2 percentage points. In addition to sampling error, one should bear in mind that as in all survey research, there are possible sources of error-such as coverage, nonresponse and measurement error that could affect the results. 
1. Academic Experience

2. Admission Eligibility

3. Job Placement Rate

4. Recruiter Feedback

5. Specialization

6. Global Reputation and Influence

According to Kushwaha, this data was collected from publicly available sources, the universities' websites, research, and surveys. It measures students' quality of education, job placements, and the recruiter's feedback — without relying on university data submissions. Also, students and industry professionals were asked to rate institutions on a scale of 1 "marginal" to 100 "outstanding," with an option for "I don't know."

Kushwaha lists thirty-six institutions, which is still too large a number for a paper of this scope. Due to this considerable number of institutions, this paper will consider the five most highly ranked institutions in the U.S. Moreover, to keep the scope more concise, the study only evaluated these institutions' Graduate Program curricula. Because the purpose of this study was to approach new perspectives for the $21^{\text {st }}$-century performer, this list excludes the core curriculum inherited from the Conservatoire - theory, analysis, musicology, aural training, and applied study were excluded; applied study was considered to include the traditional Western symphonic, vocal, and chamber ensembles. What remains can be termed the "non-canonical" courses offered by the below-mentioned institutions; these were investigated. These include:

- Elective classes related or suggested to music performance graduate students by the catalog;

- elective classes which students could perform or be part of a performance project;

- $\quad$ subjects that address today's topics such as the pandemic and other current events; 
- performance career, musicians' health, and performance enhancement;

- technology related to music performance practices. ${ }^{24}$

Certain aspects of these course offerings were not considered, including how often the courses are offered, how recently the courses have been offered, and the enrollment limits for the courses.

The institutions included in this study were:

1. The Juilliard School

2. Berklee College of Music

3. New England Conservatory

4. Yale School of Music

5. Manhattan School of Music

The descriptions of these courses, taken from the institutions' online catalogs (cited in the Bibliography), follow.

\section{The Juilliard School}

\section{GRMUS E605 - Career Development Seminar - 2 credits}

This highly collaborative seminar comprises three primary areas of focus: the finding and refinement of one's own artistic voice; the polished production of a wide array of career materials; and the hands-on acquisition of tools and experiences that open pathways to new possibilities. Also woven throughout is increasing the awareness of how to: recognize opportunity; build your team; understand behind-the-scenes thinking; find and commission a composer; walk through a job search; develop an authentic public speaking persona; harness music's power to effect change; enhance the ability to enter any situation professionally; and

\footnotetext{
${ }^{24}$ Performance practices, in this context, is related to all the aspects of putting together a performance other than playing the music: staging, inclusion of additional video and audio media, apparel, venues, online performances (including streaming).
} 
take continuous and organic action towards your career right now. Revision and completion of the significant number of weekly assignments is supported by five individual meetings with the teacher during the course of the semester.

\section{GRMUS E613 - The Musician as Entrepreneur - 2 credits}

What is your definition of success? What are your artistic goals and how will you achieve them? How can you balance your musical dreams with the reality of making a living? What is the mindset and attitude of successful entrepreneurs? Through case studies, exercises, readings, and presentations, this course is designed to encourage you to identify and cultivate your entrepreneurial potential.

\section{GRMUS E615 - Breaking Barriers: Classical Music in an Age of Pop - 2 credits}

There's been talk for years about a crisis in classical music. We've all heard that the audience is getting older, that ticket sales are down, and that funding is harder to find. In this course, we ask where classical music fits in our changing culture. How real is the crisis? What can we do to make things better? We also look at how classical music is changing. As an exercise in making change ourselves, we talk about entrepreneurship - how musicians can find their own audience, and make careers in new and creative ways.

\section{GRMUS E620 - Speaking of Music: How to Talk and Write About Music - 2 credits}

In today's climate, musicians need to reach out to their audience and to the community. To do that, they need to talk about the music they make, which is something we all can learn to do better. In this course, we play recordings in class, and find ways to describe what we hear. We also read music critics, as examples (both good and bad) of how music gets talked about, which gives you one extra benefit: you'll learn how critics work, how they think, and what your relationship with them can be, as your career advances. 


\section{GRMUS E653 - The Art of Teaching in the Music Studio - 2 credits}

This course will help students identify and develop the skills necessary to be effective private studio teachers. Through assigned readings, discussions, and observations of master teachers, students will explore learning styles, teaching strategies, assessment strategies, resources, and methods and approaches to cultivate a creative learning environment. Students will learn by doing as they teach a limited number of private lessons. Open to fourth-year undergraduate students by permission of the Registrar.

\section{GRMUS E670 - The Arts and Society - 2 credits}

This survey course examines the intersection of arts and society, looking specifically at the role of arts and artists in addressing issues facing the world today. Through extensive reading lists, case studies, individual and group projects, and conversations with distinguished guests, we will explore areas including but not limited to law, health care, education, science, and civic participation to consider our ideal version of a collective future and how we might use arts, creativity, and culture to help get us there. Past guests have included Oskar Eustis (Artistic Director at the Public Theater), Sarah Lewis (author, curator, and Harvard University Assistant Professor in the Department of History of Art and Architecture and the Department of African and African American Studies), Vijay Gupta (violinist, social justice advocate, and 2018 John D. and Catherine T. MacArthur Fellow), Caroline Shaw (Pulitzer Prize-winning composer, vocalist, violinist, and producer), Eric Liu (writer, educator, and founder of Citizen University), John Heginbotham (choreographer, performer, and founding teacher of Dance for PD), and Jeannie Suk Gersen (Harvard Law School John H. Watson, Jr. Professor of Law). Open to 3rdand 4th-year undergraduates and cross-listed as graduate elective; preference given to graduate students. 


\section{GRMUS E674 - Leadership and Innovation in the Creative Arts - 2 credits}

Individuals in creative industries face all kinds of problems that pose significant challenges to their careers. These include highly volatile career environments, competitive conditions, a complex global environment, and difficult politics and conflicts between individuals and organizations. This course looks at how leaders in the creative industries develop strategies to deal with such challenges. Stressing the importance of innovation in entrepreneurial endeavors, we will study the work of artists in different disciplines-Pina Bausch, Daniel Barenboim, and Ferran Adrià. We will also look at leaders whose initiative and foresight have had significant impact on the music industry: Klaus Heymann at Naxos, Peter Gelb at the Metropolitan Opera, and Steve Jobs at Apple. By the end of the semester, students should understand fundamental concepts in leadership, entrepreneurship, and innovation.

\section{GRMUS P660 - Introduction to Music Technology - 2 credits}

An introduction to the basic skills needed for composing and arranging electronic music. Topics of study include sequencing, sampling, and editing and processing digital audio. Basic Macintosh skills are required.

\section{GRMUS P661 - Global Influences in Contemporary Music Production - 2 credits}

This course is an exploration of contemporary music production techniques, viewed through a trans-cultural lens. Topics will include recent developments in music production, from Native American practices to Brazilian, Indonesian, and South Asian electronica; South African township and dance styles; the impact of Jamaican producers on worldwide dance idioms; and the use of technology in current film and concert music. Multiple approaches and techniques will be explored, including looping, sampling, processing, field recording, texture building, and more. Listening, viewing, and reading material will be assigned, as well as weekly compositional work, culminating with a final creative project. 
GRMUS P662 - Composing for Visual Media - 2 credits - Prerequisite: GRMUS P660.

For students interested in learning the fundamental skills needed to compose and produce music for visual media including film, television, games and emerging art forms. Topics include creative collaboration with directors and visual artists, traditional and emerging art forms, diverse styles of music composition and production, and analysis of masterworks of professional composers. Students will be required to compose and produce original scores to excerpts from feature films, documentaries, and other filmed media.

\section{GRMUS P663 - Creation, Improvisation \& Technology - 2 credits}

This course is for students embracing different forms of music making, challenging conventional distinctions between diverse styles. Students can choose their own interest and concentration without the traditional boundaries or 'genre' in music. For example, performance students can study extended technique for their instruments. String students in particular could study with the instructor on contemporary string technique and extended technique she developed, "Subharmonics", and how to incorporate such element in composition and improvisation.

GRMUS P664 - Scoring to Picture Workshop - 2 credits - Prerequisite: GRMUS P662. This intensive workshop is designed for Juilliard composers interested in music for narrative media. Students will score scenes from films or TV programs with the expert guidance of an established composer of film and TV music. The workshop experience will expose students to all aspects of the process from creation to production, including a spotting session, recording the score with Juilliard musicians, and a final film mix. 


\section{GRMUS P667 - Introduction to Interactive Music Technology - 2 credits}

An introductory class in which students will learn about the revolutionary program called MaxMSP (digital signal processing in Max), which allows musicians to perform interactive and electroacoustic computer music without any external devices such as synthesizers.

\section{GRMUS P668 - Advanced Interactive Music Technology - 2 credits - Prerequisite:}

GRMUS P667. An advanced class in which students will be introduced to the revolutionary program called MaxMSP (digital signal processing in Max), which allows musicians to perform interactive and electroacoustic computer music without any external devices such as synthesizers. Students will create and perform their own works using "Max," and will discuss aspects of performance practice and musicianship related to interactive computer music. Cutting-edge technology and musical activities on the Internet will also be explored.

\section{GRMUS P672 - From Studio to Stage - 2 credits - Prerequisite: GRMUS P660.}

For students interested in composing and producing contemporary popular music. The course will cover basic procedures and practices used in diverse contemporary and emerging musical styles including EDM, electronica, pop, rock, $R \& B$, rap and hip-hop, and various sub-genres of indie music. A variety of production and performance software will be used in class with an emphasis on Ableton Live. Projects will include original compositions produced for recorded formats and live performance.

\section{GRMUS P675 — Performance Enhancement - 2 credits}

Performance-oriented, this course presents Sport Psychology methods that have been shown to assist students in achieving optimal performance levels under the pressure of juries, recitals, competitions, and auditions. Students will learn how to deal with fear and doubts, channel nervousness, focus better, and perform at a high level in stressful situations. A Performance Skills Profile, which identifies mental strengths and areas for improvement, will be 
administered and interpreted for each student. Through a series of practical exercises and mock auditions, students will apply established strategies and techniques, such as mental rehearsal, "deep" practice, and the "Centering" process, for achieving their best when it matters most.

\section{Berklee College of Music}

\section{M-PR 70911 - The Creative Musician - 1 Credit}

Course objectives are to discern each student's personal goals in music, to expand our awareness of what is possible to do as musicians, to cultivate each person's creativity as an individual and as a collaborator, and to explore each student's potential as an imaginative performer, teacher, colleague, and creative being. This course challenges students with creative assignments and materials; includes guest presenters such as innovative performers, child development specialists, and therapeutic musicians; expands awareness of other art forms; introduces modern teaching techniques such as Dalcroze and Music for People; and provides a place for open dialogue. Offered in the fall semester only.

\section{M-PR 70912 - Alexander Technique for Musicians - 1 Credit}

An introduction to F.M. Alexander's techniques of body and mind awareness, alignment, and relaxation for the performing musician. Undergraduate and graduate students in Music may elect this course. May be repeated for credit up to a total of four credits.

\section{M-PR 70914 - Adv Alexander Technique for Musicians - 1 Credit}

This course is an in-depth approach to the Alexander Technique. Students will find solutions for moving into more easeful ways of being with themselves as artists. We will examine performance preparation and practice performance skills to fully prepare students for the challenges of performance. 


\section{M-PR 70916 - Advanced Career Skills for Musicians - 1 Credit}

The goal of this course is to prepare students to examine long-term career prospects and devise a plan for integrating artistic career aspirations with supplementary and/or complementary employment. This includes exploring the fundamentals of job hunting and the creation of employment materials for a wide variety of artistic, non-artistic, and academic employment opportunities; entrepreneurship and business planning; exploration of nonprofit institutions; and advanced financial issues for musicians.

\section{New England Conservatory}

\section{CMP 551 - Introduction to Music Programming in MAX - 2 Credits}

This course will serve to introduce students to the basic elements and practice of music programming, using MAX/MSP music programming language. Developed in 1986 at the Institute de Recherché et de Coordination Acoustique/ Musique (IRCAM) in Paris, MAX is an ideal music programming environment for composers, theorists and performers alike. Operating on both Windows and Macintosh platforms, MAX is a graphical programming language that invites the user to design music software by connecting together "ready made" musical objects onscreen. Using this intuitive flowchart language structure, students will quickly learn the substance and concepts of music programming, while at the same time, avoiding the lower level details of programming that encumber older computer languages. As the elements of the language are mastered, students will be encouraged to develop their own musical thinking towards a final project comprised of a MAX application, an active demonstration of their software, and a short description of their project. These final projectswhich may take a range of different forms, including compositions, performance environments or theoretical tools - will serve to connect to the student's personal musical goals to the practice and craft of music. 


\section{521 - Third Stream Methodology I - 2 Credits}

Readings and Creative Projects in Contemporary Improvisation and Global Musicianship In this class we will use readings, musical examples, discussion, performance and class projects to consider what it means to be a "contemporary improviser/ musician."

\section{522 - Third Stream Methodology II - 2 Credits}

Non-Western Model Composition and Improvisation Music traditions, including Bali, Japan, China, Middle East, and India. Concepts of time, phrasing, rhythm, texture, timbre, and form will be explored through these various musical traditions. The class is organized in four main units: 1) Modal music: study of the modal music of Arabic, Persian, and Indian music from the point of view of their structure, phrasing, gesture and intonation. 2) Rhythmic concepts, with a focus on long rhythmic cycles of Turkish/Arabic music (Iqa) and Indian Tala. 3) Texture and timbre, based on Gamelan ensemble of Balinese music, Japanese court music (Gagaku), and Qin music of China. 4) Recomposition: study of selected compositions of 20th century music which use elements of non-Western cultures. The concept of composition in this class can range from a completely written piece of music (the most common way of composing in the West after the 17th century) to a non-notated composition where the composer teaches the piece to the performers by ear, to other forms of partially-notated compositions.

\section{551 T - Issues and Trends in American Music - 2 Credits}

Through presentations from many voices within and outside the conservatory, readings, and group discussions, the class will explore the dimensions of American music, learn something about various streams of musical activity in America, attempt to understand what is "American" about American music, consider the impact of regional and ethnic musical subcultures and "world music," grapple with the potential impact of technology, and consider today's trends as indicators of the future. 


\section{568T - Music, Spirit and Transformation - 2 Credits}

This course explores the concept of transformation and transcendence through music by examining its use and purpose in various world cultures and religions. The desire to connect spiritually through music is virtually universal, but music also communicates that which is beyond language in both sacred and secular settings. We will explore the idea that music is powerful and expand our definitions of "sacred" and "spirit." Through guided listening, viewing documentaries, class discussions, and interdisciplinary projects we will explore the forms and contexts of music from around the world and make connections between music, transformation and spirituality.

\section{569T - Eco-Music - 2 Credits}

This course teaches how music has made and can make a difference in dealing with environmental and social justice issues through active engagement with such issues, musical participation, and the process of listening; through elevated listening, music can raise consciousness leading us to feel more deeply and act on our convictions. We will discuss repertoire that has played a role in raising awareness of environmental and social issues and work toward preparing individual creative and performance projects with an environmental focus.

\section{587T - Seminar in Performance - 2 Credits}

Focuses on developing and expanding students' artistic sensibility through performance and discussion. Integrates advanced aural, theoretical, compositional and performance skills into individual aesthetics. Provides insights into concert preparation, career strategies, and development of repertoire. Recommended for students in their final semester, in preparation for their degree recitals. 


\section{WKSHP - Contemporary Improvisation Workshop - 0 Credit}

This course provides in-depth applied study through hands-on opportunities to create, develop, and workshop: techniques of composition, improvisation, and performance; listening and analysis skills; rehearsal and pedagogical strategies; repertoire in a broad array of styles and genres; other issues relevant to the professional aspect of our lives as artists, teachers, and students. It serves as a lab or workshop setting in which CI students connect and put into practice all of the information they take in at NEC. Students engage with specific repertoire or concepts to develop three department productions in Jordan Hall in addition to 128 Course Offerings and Faculty by Department smaller performances. During the process, students are expected to contribute works (originals, recompositions, covers, arrangements, etc) and participate in discussions and constructive critique. This course is an integral part of Contemporary Improvisation curriculum, and is required for all CI majors as a corequisite when registered for studio/CI ensemble.

\section{ENTP 551 - The Entrepreneurial Musician: Graduate Seminar - 2 Credits}

This class prepares young artists to become social problem-solvers, advancing the role of the performing arts in a rapidly-changing world. This class is about a mindset (ways of knowing, thinking, interacting and being) that is directly relevant to your artistry, your career, and your academic pursuits. Students participate actively by contributing their skills, artistry and knowledge of the world around them to make a positive impact. This class is designed to not only improve students' conceptual understanding of entrepreneurship as it relates to the performing arts, but also to engage in experiential learning. Lectures and class discussions will provide an overview of Social Entrepreneurship and Design Thinking, and use them to explore existing and emergent models for musicians' professional roles, incorporating the pillars of entrepreneurial thinking—vision, initiative, risk, and value. 


\section{ENTP INT - Entrepreneurial Internship - 0 or 1 Credit}

EM Internships are offered in conjunction with local arts organizations and ensembles, including the Boston Symphony Orchestra, Boston Ballet, and A Far Cry, among others. Interns work directly with a professional from the host for 70-80 hours over the course of a semester. Grading is pass/fail, based on the intern's self-evaluation and the host manager's performance evaluation. Internships are eligible for one credit or zero credits; paid internships are not eligible for credit.

\section{ENTP 552T - Grant Writing and Fundraising for Artists - 1 Credit}

This course presents the principles, strategies, and tactics necessary to author successful funding proposals as an individual artist. The ability to generate content and edit prose in a compelling way largely determines the value others will find in one's work. We will explore direct grants, fellowships, scholarships, sponsorships, and other situations in which a musician's work must be communicated to another for their benefit. Students will have the opportunity to create projects and author proposals that accurately reflect their own work and career trajectory, while adding to their skill set to keep future efforts articulate, compelling, organized, and ultimately funded.

\section{ENTP 553 - Music Law 101: Copyright Basics - 1 credit}

Artist contracts, copyright law, recording and music publishing agreements, digital rights management, and business organization-music-related careers are affected by legal matters on a regular basis. This course provides an introduction to the legal issues surrounding United States copyright that individuals working in the music business face today. Students will complete the course with a foundation of knowledge in how to protect their own works from unauthorized exploitation. 


\section{ENTP 554 - Creating an Audience: Marketing Basics - 1 Credit}

So you have a great artistic product—how do people find out about it? In this course, students will learn how to reach beyond the community they already know to get the word out about their work to the world beyond. Using real-world case studies, you will build your individual or organizational brand identity and apply that identity to building functional outreach strategies. Relying heavily on an audience-centric approach, students will learn the tactical skills necessary to bring a project, performance, or product to market through practical assignments directly applicable to their individual or ensemble careers.

\section{ENTP 556 - Finance 101: What Musicians Need to Know - 1 Credit}

This course is designed for musicians who will soon be transitioning to the professional world and have a desire to better understand and control their finances. It will provide a systematic approach to learning essential finance skills and will promote habits for long-term financial health. Course topics will include financial planning, saving and credit, loan management, taxes, insurance, and retirement planning. Additionally, the course will address how to create and work within a budget for both personal and professional projects.

\section{ENTP 558T - EM Expo Seminar: The Journey from Thinking to Creating - 1 Credit}

You have an idea for your own artistic project outside of NEC's walls, but how do you actually make it happen? In this course, students will be supported to think deeply about their goals and learn how to develop a plan to support an artistic project of their own choosing. The course will explore how artistic projects - including those created by NEC alumni - are developed, introduce the elements of planning, and provide students with an opportunity to design plans for their own projects. 


\section{INT 559T - Body Mapping I - 1 Credit}

The powerful course "What Every Musician Needs to Know About the Body" offers practical strategies to decrease tension, prevent pain and injury, and unleash expressive potential while cultivating healthy habits that are important for injury prevention. Hands-on workshops guide instrumentalists and vocalists in an exploration of three important facets of music-making: training movement, training the sense and training attention. Together these areas empower musicians with enhanced coordination and optimal awareness.

\section{INT 561T - Body Mapping II - 1 Credit}

Body Mapping II adds maps of the extremities: arms, hands, legs and jaw, to the musicians' movement library. Participants will understand how the extremities move and their relationships to balance, breathing and awareness. Class activities will guide participants to understand and experience these new maps in their playing to enhance playing ease and precision, resolve pain and discomfort, release tension, and performance confidence.

\section{INT 571T - Music and Social Change - 2 Credits}

How can music serve as a vehicle for social change? This course provides an overview of the ways that music can promote human and social development, poverty alleviation, conflict resolution, peacebuilding, and social justice, drawing on scholarship and examples from all of these fields. We'll look at orchestras in Venezuela and inner city schools in the US, AfroReggae groups in Brazil's most violent favelas, peacebuilding programs in the Middle East, songs in the civil rights, Black Lives Matter, anti-apartheid and climate justice movements, music and the Arab spring, prison choirs, and more. We'll draw on research to learn what conditions must be in place to ensure that such programs are effective, and to avoid potential pitfalls. The goal is for students to not only understand the many ways that music can serve as a significant social resource and mobilizer (for good or ill, depending on one's perspective), 
but also to think critically about such programs, asking insightful questions, identifying and weighing assumptions, evaluating theories of change, and applying lessons learned in new contexts. Students will leave the course with practical knowledge and concrete tools they can incorporate into their own musical activities. The course will draw on case studies, presentations, guest speakers, readings, videos, participatory activities, and the personal experiences of students.

\section{INT 574T - Creative Recording Concepts for Musicians - 2 credits}

Whether a musician is recording ideas into a smartphone or working in a multimillion dollar studio, recording is both utilitarian and inspirational. Musicians use recording technology constantly-recording lessons and practice, making audition demos, sketching out ideas for compositions, posting songs and videos online-but frequently are unaware of recording technology's full potential to shape our work and access new creative opportunities. This course explores skills and models for maximizing the practical and creative role of recording in our work as performing musicians. Today our phones, tablets and computers contain advanced audio technology that far surpasses the possibilities of even professional studios from a few years ago. How can we use that potential to enhance our artistic practice and help our music reach audiences around the world? Technical and creative concepts are interwoven with style and genre, but how can musicians access the full range of possibilities regardless of their music's idiom? Musicians have nearly unlimited opportunities to take advantage of this crucial tool. How can contemporary musicians use this freedom to maximize their creative potential? Lectures are grouped around examples from across the spectrum of recording technique, contemporary practice, and historical models; in-class demonstrations of technical concepts; and practical application. Over the course of the semester, students explore the vast options 
available to utilize the infinite potential of recording technology, and gain the skills and knowledge needed to use technology effectively both with the tools they already have and as it continues to develop into the future.

\section{INT 701T - Performing Musicians and Community Health - 1 Credit}

This course offers students the opportunity to explore the current landscape of arts and community health. Students will gain a broad introduction to NEC Academic Catalog : 2020 / 2021133 trends and best practices in the field, and will have the chance to interact with healthcare professionals from a wide range of disciplines. Through readings, class discussion, and lectures by guest speakers, students will develop an understanding of the role music can play in healthcare settings, as well as the possibilities for developing meaningful partnerships with key stakeholders. Students will learn how to confidently engage audiences from diverse community healthcare constituencies, and will design and perform an interactive program for a specific healthcare setting. Throughout the course, emphasis will be placed on utilizing tools for reflection and evaluation of one's own work and that of peers.

\section{$\underline{\text { Yale School of Music }}$}

\section{MUS 578b, Music, Service, and Society - 4 credits}

What are the impacts of music on the conditions of a society? How have music and musicians been present and catalytic to important historical moments? How can we think about reinvigorating the participation of musicians in the public sphere, the public square? How do we think about the roles and activities of musicians in today's world? What are the potentials for artists and arts practices to positively influence the direction of our society? What are the mechanisms for artistic voices to play a role in activating conversation and transforming experience? How can we think about invigorating the participation of musicians in the public sphere? Through texts and discussion, we reconceive the roles artists can play in the 
communities in which they work. We explore the concept of the social imagination- the ability to imagine different scenarios, different futures for people in the world, and in our communities.

\section{MUS 621a, Careers in Music: Innovation and Collaboration for Arts Leadership in the Post-COVID-19 World - 2 credits.}

This course teaches entrepreneurship and leadership through innovative collaborative termlong projects exploring artistic solutions in the post-COVID-19 world. Working from the psychological framework of the growth mindset and emotional intelligence, students articulate their artistic missions and choose collaborative project groups based on common missions. They learn how to innovate using the creativity problem-solving process and design thinking. Students create, pitch, and implement artistic projects in an environment that encourages taking risks and learning from experience. Students also learn the art of collaboration, including communication skills and leveraging communication styles, conflict management, and effective persuasion and presentation. The class combines instruction with group discussion, coaching, and feedback from fellow students, faculty, and professional and alumni mentors.

\section{MUSI 458 Sex and Sensibility in Early Opera}

This seminar investigates historical ideas about the body through the lens of opera in the 17 th and 18 th centuries. How did people in the early modern period conceive of what we call gender and sexuality? How did they explain the ways that bodies experience physical sensations and emotions? And what might early modern operas reveal about such notions in representing them through music and performance practice? We explore these questions by studying twentiethand twenty-first-century scholarship on sexuality, gender, the body, and music history alongside scientific, philosophical, and musical primary sources from c.1600-1800. At the same time, we consider these questions through case studies of operas including, but not 
limited to: L'Arianna (Monteverdi), Il Giasone (Cavalli), Armide (Lully), Alcina (Handel), La serva padrona (Pergolesi), Orfeo ed Euridice (Gluck), Zémire et Azor (Grétry), Nina, o sia La pazza per amore (Paisiello), Le nozze di Figaro (Mozart), and Pimmalione (Cimador). The goals of this course are to invite students to think critically about how the body has been constructed as a site of feelings, desires, and identities, and to interrogate notions of the body through the sounds of early modern opera.

\section{MUSI 493 - Caribbean Music, Sacred Ecologies, and the Environment}

A consideration of sacred ecologies and the environment through a range of Caribbean music and religious practices, with a particular emphasis on environmental justice. Course draws on current discussions in ecomusicology, acoustic ecology, sound studies, Caribbean intellectual traditions, and indigenous theory.

\section{Manhattan School of Music}

\section{ME1600 - Orchestral Entrepreneurship - 2 credits}

The course is designed to equip orchestral students with the knowledge and perspective needed to succeed as professional orchestral players in a changing industry. The class covers essential organizational, financial, and programmatic issues affecting orchestras and their entrepreneurial possibilities for the future. Includes guest speakers from the League of American Orchestras, American Federation of Musicians Symphonic Services Division (the Union), and others.

Note: The course is designed for graduate students in the Orchestral Performance program and is also available to others with permission from the instructor. 


\section{ME1500 Practical Foundations: Entrepreneurial Leadership Skills}

Focusing on creativity, innovation, value creation, and impact, this core course explores the basics of establishing a professional career. The class covers marketing, communication, financing, community engagement, and project management-for both new and traditional career paths. This is a required class for all undergrads.

\section{SP1070R2 Preparing the Exit}

This course will challenge the artist to create the ten-minute performance that may lead to a three-hour professional engagement. Today's artist must be prepared not only to show their expertise, control, consistency and dependability, but also an inspired, exciting, unique, courageous and memorable experience for the listener. We will work with a varied repertoire including Opera, Musical Theater and Cabaret and will also be "auditioning" for professionals in various venues.

PN2450 The 21st-Century Pianist: Exploring Performance Strategies and Techniques in Contemporary Music - 3 credits

A seminar/master class format providing the context for the exploration of contemporary performance practices, interpretative strategies, extended techniques, and the incorporation of multi-media in 20th and $21^{\text {st }}$ century piano music. In-class performances and coaching will facilitate discussion of related aesthetic issues, creative programming strategies, and skills relating to audience development. 


\section{PT0100 Foundations of Critical Inquiry - 3 credits}

This course investigates these inter-related questions: What is true criticism--in art and in life? What makes a person an honest and valuable critic? And what can interfere with a person being an accurate judge of value? Classic texts are studied, including Pope's 1711 Essay on Criticism, Siegel's 1922 essay The Scientific Criticism, and Six Names of Beauty by Sartwell (2004). The varying perspectives on criticism had by different disciplines-- including economics, psychology, and anthropology--are considered, and examples of recent writing in these disciplines are evaluated. Throughout, students study the relation of these various texts to the art of music: from Beethoven to the Beatles, Wagner to Gershwin, Stravinsky to Hip- Hop, Mozart to the composers of contemporary film scores.

\section{PT1200 Community Outreach for Musicians - 1 credit}

Students in this course will learn how to create and present effective, interactive, and meaningful performances for underserved outreach audiences. Lectures will focus on music and the brain, memory, and healing. Guest speakers will include experts in the field of gerontology, Alzheimer's Disease, developmental disabilities, and music therapy. Students will perform at various local community venues including hospitals, senior residences, and Alzheimer's facilities.

\section{PT1500 Curricular Practical Training - .5 credits per semester}

This course is designed to allow a student to participate in exceptional, off-campus performance experiences such as orchestral/chamber music, solo concerts, church accompanying, music teaching, and internships, as an opportunity to enhance their performance skills as an integral part of their individual degree programs. The individualized project must be approved by the appropriate Department Chair, the Dean of Academics Affairs, 
and, in the case of international students, the International Student Advisor. At the end of the semester, the student must present a formal, written report on the project, which will be evaluated by the Department Chair.

PT1620 Alexander Technique - 2 Credits per semester

A study of the Alexander Technique and its application to playing/singing. Addresses both individual and universal physical habits that deter easeful, healthy performing. Taught through hands-on work, reading, anatomy, and application of the technique while performing. Short individual sessions in addition to group class.

PT1622 Advanced Alexander Technique - 1 Credit per semester - Prerequisite: PT1620 A small group class focused on the application of the Alexander Technique to making music. Frequent playing opportunities, reading, hands-on work. Frequent short individual sessions in addition to group class.

PT2011-2012 Advanced Teaching Techniques - 2 Credits per semester

An exploration of teaching and learning strategies. How students learn problem solving, motivation, assessment; with practical application to the methodology of studio teaching for all instrumentalists. How to maximize results from beginners through advanced students.

PT2061-2062 Performance Techniques - 2 Credits per semester

A class for performers that will cover: anxiety-reducing techniques, concentration, and memorization techniques, skills for developing peak performance. Advanced repertoire will be explored. 
PT2800 Biomechanics/Ergonomics for Performers - 2 credits per semester

A class designed to help instrumentalists develop peak performance skills and that will cover basic physiology as it relates to performers, anatomy (upper body), anxiety reducing techniques, and ergonomics/ biomechanics with practical application for each instrument.

WW2151-2152 Woodwind Lab - 2 credits per semester

A seminar devoted to developing both the performance and extra-musical skills required of today's professional musician. The labs include sessions on orchestral excerpts, auditioning, programming, chamber music and concert presentation. Students have the opportunity to perform for guest artists who are leading experts in their fields. Required of all junior, senior, and graduate flute, oboe, clarinet, and bassoon majors. 


\section{$\underline{\text { Reflections on the Selected Courses }}$}

Among the fifty-seven courses analyzed in this section, ${ }^{25}$ we can observe a considerable emphasis on career development and music technology subjects. In the present day, technical proficiency is not enough. It seems that creativity and innovation are the new mottoes for today's musicians. For instance, the advent of video platforms such as YouTube seems to have increased the chances of being seen and recognized among our peers worldwide. Moreover, in virtual environments such as social media, it appears that to be famously acknowledged nowadays, performers need to offer much more than a technically accurate performance and pleasant sound to obtain the audience's attention. Elements such as a captivating background, an "outside the box" approach, technological effects, filters (both sound and visual), audience interactions, etc., seem to be essential to the new generations.

The chart below portrays the courses offered by the five institutions previously cited. Due to the impracticability of displaying all subjects in the chart, these are grouped into eight macro-areas, to wit:

- Career development

- Music Technology

- Performance

- Arts and Society

- Musician's Health

- Pedagogy

- Creativity

- Other

${ }^{25}$ See Appendix D. 
The proportional distribution of these eight areas can be seen graphically in Figure 1.

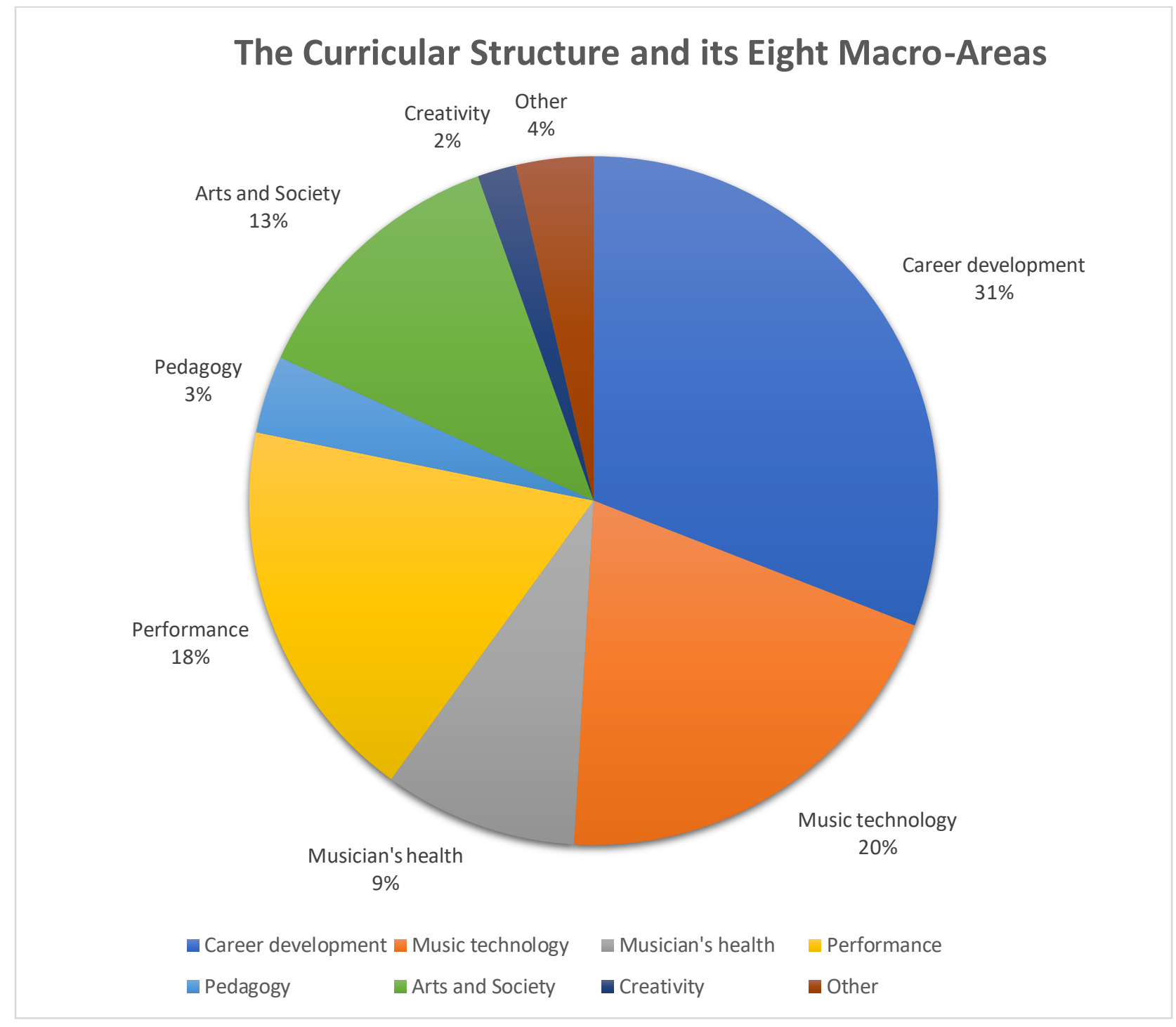

Figure 1- The Eight Macro-Areas

In the chart above, we can observe a substantial percentage of disciplines focusing on career development and technology. The third largest area, performance, is of course vital to the training of performers. On the other hand, we can notice fewer courses focusing on creativity per se. This suggests that:

1. The analyzed institutions understood that today's performers need to learn how to develop, manage, and promote themselves.

2. These institutions understood that technology skills, or some elements of them, should be more consistently present in the routine and performance practices of the students. 
It is interesting to consider why these topics are emerging now; conversely, why did they not emerge earlier?

Perhaps, one of the reasons why 20th-century musicians were not aware of these subjects might be related to the "Fordism phenomenon." ${ }^{26}$ Its consequences profoundly shaped the past century, and musicians could not escape from its influences, with its near-monolithic emphasis on a specific bifurcated career track: get a good education and then get a stable job in either an orchestra or in a tenure-track teaching job.

Whilst in the "Pre-conservatoire era," when the formal music training was based on the Master-apprentice relationship, musicians had to promote and support artistic activities by themselves. In that respect, today's musician mindset needs to be, in a sense, more similar to the pre-conservatoire musician mindset than the $20^{\text {th }}$-century "Fordist" musician mentality. For several reasons, those who today aspire to a career performing concert music cannot learn and act as $20^{\text {th }}$-century music students did. Therefore, we would benefit from recapturing some of the actions, initiatives, and behaviors demanded in the Pre-conservatoire period when formal music training was based on the Master-apprentices relationship and when musicians were artists-entrepreneurs. ${ }^{27}$

These expectations demand that $21^{\text {st }}$-century concert musicians learn and master skills related to technology such as microphone selection and placement, video communication software and related platforms, sound editing, equalizer adjustments, video editing, etc. Another significant impact on today's musicians is the almost-mandatory ability to teach and

\footnotetext{
${ }^{26}$ Fordism: a technological system that seeks to increase production efficiency primarily through carefully engineered breakdown and interlocking of production operations and that depends for its success on mass production by assembly-line methods. Merriam-Webster.com Dictionary, s.v. "Fordism," accessed October 22, 2021, https://www.merriam-webster.com/dictionary/Fordism.

${ }^{27}$ Antonio Santoni Rugiu, Nostalgia do Mestre Artesão (Campinas, SP: Autores Associados, 1998) offers a comprehensive bibliography and study on the master-apprentices relationship, guilds, corporations, and organizations from the $12^{\text {th }}$ century to $18^{\text {th }}$ century, as well as the role of the teacher and pedagogical teaching processes during this period.
} 
(even) rehearse online. It requires today's artists to make a constant effort to keep updated on this matter.

\section{Section III \\ The $21^{\text {st }}$ Century Performer: A Contemporary Professional Perspective}

How should the $21^{\text {st }}$-century musician approach this era and its complexity? What skills should musicians know or develop according to market demands?

To answer these questions, it is crucial to understand how the current Zeitgeist has reshaped the idea of learning and work. Since the time of the French Revolution, Western society faced four majors turning points: the First Industrial Revolution, the Second Industrial Revolution, the Third Industrial Revolution, and the current one, the Fourth Industrial Revolution. Klaus Schwab, Founder and Executive Chairman of the World Economic Forum, is considered the first scholar to bring this latter revolution to our attention. He states that:

The First Industrial Revolution used water and steam power to mechanize production. The Second used electric power to create mass production. The Third used electronics and information technology to automate production. Now a Fourth Industrial Revolution is building on the Third, the digital Revolution that has been occurring since the middle of the last century. It is characterized by a fusion of technologies that is blurring the lines between the physical, digital, and biological spheres. There are three reasons why today's transformations represent not merely a prolongation of the Third Industrial Revolution but rather the arrival of a Fourth and distinct one: velocity, scope, and systems impact. The speed of current breakthroughs has no historical precedent. When compared with previous industrial revolutions, the Fourth is evolving at an exponential rather than a linear pace. Moreover, it is disrupting almost every industry in every country. And the breadth and depth of these changes herald the transformation of entire systems of production, management, and governance. The possibilities of billions of people connected by mobile devices, with unprecedented processing power, storage capacity, and access to knowledge, are unlimited. And these possibilities will be multiplied by emerging technology breakthroughs in fields such as artificial intelligence, robotics, the Internet 
of Things, autonomous vehicles, 3-D printing, nanotechnology, biotechnology, materials science, energy storage, and quantum computing. ${ }^{28}$

As a reflection, it is interesting to observe how these new technologies and concepts tend to take more time to be incorporated into the music training process than in other fields such as sports, computer science, or medical-related areas. Since classical musicians' training is commonly compared to athletes' preparation, it seems reasonable for musicians to take greater advantage of the technologies used in sports, such as video analysis software, 3D physiology and body composition imaging, and data analysis for individual and team performances. While this paper will not expound on how such technological advances might enhance musical training, this topic will be covered in one of the proposed courses later in the Sample Syllabi section.

\section{Today's Performer}

Whereas, for the $18 / 19^{\text {th }}$-century musician, it was enough to be highly technically proficient in the art, its aesthetics, and instrumental techniques, the $21^{\text {st }}$-century performer, besides the already mentioned skills, must also be in harmony with today's demands. According to Greg Sandow, there are many ways to define a 21st-century classical musician. ${ }^{29}$ This is expanded upon by Mark Rabideau, ${ }^{30}$ who believes that today's musicians portray the following characteristics:

- they go their own way;

\footnotetext{
28 Klaus Schwab: The Fourth Industrial Revolution: what it means, how to respond https://www.weforum.org/agenda/2016/01/the-fourth-industrial-revolution-what-it-means-and-how-to-respond/ ${ }^{29}$ Greg Sandow, "What is a $21^{\text {st }}$ Century Musician?" Originally published at $h t t p: / / 21 \mathrm{~cm}$. org $/$ magazine/state-ofthe-art-form/2015/01/13/what-is-a-21st-century-musician, quoted in Mark Rabideau, Creating a Revolutionary Artist: Entrepreneurship for the $21^{\text {st }}$-Century Musician, by (Rowman \& Littlefield, 2018), page 5.

${ }^{30}$ Mark Rabideau, Creating the Revolutionary Artist, page 5. Due to a website update, currently, this article can be accessed at https://drive.google.com/drive/search?q=\%E2\%80\%9CWhat\%20is\%20a\%2021stCentury\%20Musician\%3F\%E2\%80\%9D
} 
- they perform or compose the music they like, in the way they like. And that music isn't always classical;

- they make their own opportunities. They shape their careers like entrepreneurs, and might produce their own performances.

Although the institutions mentioned in Section II have been offering elective classes on relevant subjects related to today's demands, since they are not required, one can graduate from these institutions without enrolling in these courses.

This feature — one might even call it a tension or an idiosyncrasy- raises more concern when we investigate what is in the graduate curricula of these institutions. This paper does not intend to discuss or suppose the reasons why this apparent reluctance to reform persists among "classical" musicians and some music institutions. This document aspires to propose alternatives to the $21^{\text {st }}$ Century music student and offer to music institutions an alternative core curriculum that addresses the Fourth Revolution and the current Zeitgeist.

\section{$\underline{\text { The Curriculum }}$}

In Section I, we saw how the founders of the Conservatoire were concerned with and focused on designing a curriculum that would develop systematic methodologies to guide the professeurs into this new system and ensure that all students would receive the same music training. Furthermore, by establishing these pedagogical guidelines, the founders of the Conservatoire could make sure that pupils would acquire the required professional knowledge and values to fulfill their roles as artists in society.

Such timeless concerns help us to understand the enduring character of a curriculum, its importance, and its resistance to change. Elliot Eisner states that "The curriculum is central to any educational enterprise. The curriculum constitutes that array of activities that 
give direction to and develop the cognitive capacities of individuals." 31 As a result, considering the goals of the "founders" and the statement of Eisner, we could infer that a curriculum is essential to introduce and establish disciplinary standards to the learners. In the context of this document, it teaches an aspiring musician how to be a professional. A deeper reflection on this inference induces us to adjoin an additional crucial adjective to the noun "standards." An adequate curriculum should also consider the current disciplinary standards of the craft and provide tools and resources to aid the students in developing their skills accordingly.

Before introducing new curricular ideas, it must be clarified that these are proposed within the context of higher education within the United States and that this a reflection of the standards put forth by the National Association of Schools of Music (NASM). The association was founded in 1924 to secure a better understanding among institutions of higher education engaged in work in music. It helped to establish a more uniform method of granting credit; and it set minimum standards for the granting of degrees and other credentials. NASM has been designated by the U.S. Department of Education as the agency responsible for accrediting free-standing institutions that offer music and music-related programs (both degree- and non-degree-granting), including those offered via distance education. ${ }^{32}$ The organizational principles of graduate study in music as stipulated by this organization are included in Appendix C.

\footnotetext{
${ }^{31}$ Elliot Eisner: "The Centrality of Curriculum and The Function of Standards." In The Arts and the Creation of Mind, 148-77. Yale University Press, 2002. http://www.jstor.org/stable/j.ctt1np7vz.10.

Elliot Wayne Eisner (March 10, 1933 - January 10, 2014) was a professor of Art and Education at the Stanford Graduate School of Education, and was one of the United States' leading academic minds. He was active in several fields including arts education, curriculum reform, qualitative research, and was the recipient of a University of Louisville Grawemeyer Award in 2005 for his work in education as well as the Brock International Prize in 2004. https://en.wikipedia.org/wiki/Elliot_Eisner

${ }^{32}$ NASM Handbook 2020-21, page 1.
} 
This paper defends the view that a curriculum is a living organism in moto perpetuo. It should reflect the thinking, ideas, ideals, and needs of its environment and time. Eisner argues that "Standardized teaching, from an educational perspective, is an oxymoron." 33 Among other conclusions, we can infer that Eisner suggests a careful reflection of the role of the instructors and the related resource in the teaching process.

Given all ideas, insights, and preliminary conclusions observed so far and based on the author's academic experience in two different countries, this document can reflect on the initial framing premise:

\section{What if the core curriculum for graduate students in music performance were} designed to prepare students to succeed in the world of the Fourth Industrial Revolution?

To work on and establish the proposed idea, instructors, faculty members, and school administrators would need first to become familiar with the current skills, cultural agenda, and technological knowledge demanded and expected in the Fourth Industrial Revolution Era. The second step would need to consider the feasibility of implementing this project in their institutions. The latter step would likely require a curricular accommodation to satisfy the requirements demanded by the organizations or state departments responsible for conferring accreditation to the music institutions (especially, but not limited to, NASM). This paper will not go further into these administrative issues because this document intends to raise awareness and provide pedagogical tools on this matter; the topic of bureaucratic negotiations lies beyond its scope. Each institution will have to develop its own academic transformational process and cope with the implications for accreditation.

\footnotetext{
${ }^{33}$ Elliot Eisner: The Educational Imagination: On the Design and Evaluation of School Programs. New York: Macmillan, 1979.
} 


\section{The Proposed Curriculum and its Main Bibliography}

To provide possible solutions to the questions proposed in Section III, the author compiled "the main bibliography" that could substantially support the proposed curriculum. This bibliography includes selected books related to the topics and subjects explored in the syllabi sample section and that have been published since $2009 .{ }^{34}$ Thus, the author identified the most recent and comprehensive books analyzing the current issues and proposing solutions to the $21^{\text {st }}$-century performers.

Since these books cite the most current and relevant sources on these subjects in their footnotes, references, article citations, and bibliographies, they make a fine base for expanding one's reading. Based on these points, and supported by the courses analyzed in section II, these new courses are designed with two intentions in mind:

- to stimulate music institutions to rethink their music core curricula and introduce new curricular alternatives, especially into the graduate school curricula in the USA and worldwide;

- to help broaden the academic and professional scope of music graduate students and professional musicians in the area of concert music. ${ }^{35}$

The connection between the ideas presented above and this body of current literature will be made clear by a brief review of each book.

\footnotetext{
${ }^{34}$ The author delimited the range of sources to be analyzed for this bibliographic section considering the material produced since 2009, which means, 10 years before the approval of Doctoral candidacy of the author, in 2019, until the current year, 2021, with one exception to allow for use of a previous edition (discussed below).

35 The author reiterates that the standards of what it means to be a proficiently apt music performer have vertiginously changed. Although we believe that the referred institutions in this study have provided their best to help their students to accomplish their professional goals, we comprehend that the $21^{\text {st }}$ century demands new perspectives and new approaches. This document intends to enlighten and proffer ideas to contribute to this new era.
} 
Creating a Revolutionary Artist: Entrepreneurship for the $21^{\text {st }}$-Century Musician, by Mark

Rabideau (Rowman \& Littlefield, 2018).

In this book, Rabideau shares his ideas and suggestions on how artist-entrepreneurs should develop the mindset and skills necessary to face this new century. He provides insights and solutions to increase audiences through creative action and community involvement. At the time of publication, Rabideau worked as director of the 21 st Century Musician Initiative (21cm.org) at DePauw University; he is now Associate Dean for Academic and Faculty Affairs at the University of Colorado, Denver. In his book, he addresses business and project management for classical musicians, presenting cases studies involving renowned musicians, and including discussions of diversity and inclusivity, entrepreneurship, and leadership. ${ }^{36}$

His book has eleven chapters, exploring topics and issues largely common for musicians, such as careers in music performance and other possibilities or engagement with the audience- "real-life" topics that academia often approaches with timidity. This Epilogue section, "From Single Project to a Rewarding Career: Continuing the Revolution," 37 provides a comprehensive guide (called by the author a "Toolkit") ${ }^{38}$ teaching step-by-step how to proceed to develop an artistic project and build a prolific music career. This "Toolkit" deserves special attention, to the extent that students might use it as daily reading.

In the "How to Use This Book" section, ${ }^{39}$ Rabideau outlines his own view of what the reader should expect from his book:

Creating the Revolutionary Artist: Entrepreneurship for the 21st-Century Musician is a selfdirected course of study that explores the mindsets of the artist-entrepreneur and develops the

\footnotetext{
${ }^{36}$ Short bio extracted and edited from the back cover of the book. Currently, Mark Rabideau is the Associate Dean for Academic and Faculty Affairs at the College of Arts \& Media (CAM) at University of Colorado Denver, and the President of The College Music Society.

${ }^{37}$ Page 147.

38 Page 151

${ }^{39}$ Page xiii.
} 
skill sets to move your ideas into action. The goal of the book is to open the reader's imagination about what is possible within a 21st-century music career and how engaging communities in meaningful projects can help build sustainable careers and lifelong partnerships. Here is what you should expect from the book:

- Chapters that challenge you to think differently about your own entrepreneurial spirit

- Leadership advice from some of the most influential thinkers within the field of music entrepreneurship

- Activities to develop creative problem-solving strategies

- A Toolkit of how-to worksheets and examples

- Case studies of revolutionary artists in today's world

- Related articles and interviews found on 21CM.org, a resource for 21st-century musicians.

The Entrepreneurial Muse: Inspiring Your Career in Classical Music, by Jeffrey Nytch (Oxford University Press, 2018).

In this book, Jeffrey Nytch explores how entrepreneurship is now fundamental to establishing a career as a performer of concert music. This is addressed in a "classical" music setting, inspiring students, emerging professionals, and educators alike to gain the broader perspective and strategic understanding required to negotiate the complex and ever-changing landscape of a professional music career. The author's own career journey creates an additional narrative intended to inspire a broader and more creative view of career possibilities.

As the back cover suggests, "Listeners will acquire strategic and observational tools designed to expand their view of possible career paths in classical music, stimulate creative thinking about how their unique skills can find value in the $21^{\text {st }}$-century marketplace, and realize their professional goals through the entrepreneurial process. ${ }^{40}$ And because entrepreneurship is itself a creative endeavor, listeners learn how entrepreneurship and artistic integrity in music can not only peacefully coexist, but actually nurture and inspire each other.

\footnotetext{
${ }^{40}$ Extracted from the back cover of the book.
} 
Nytch starts the Preface section by offering an overview of the history of the first conservatories in the USA, and he briefly describes how these institutions coped with the career path at that time. Nytch, who serves as the Director of the Entrepreneurship Center for Music and Associate Professor at the University of Colorado-Boulder, affirms that "Career paths were few, well known by all, and specific; training beyond mastery of the instrument was not even conceived of, much less required." ${ }^{41}$ Nytch argues that the post-war era and the GI Bill produced unintended consequences such as the explosion of colleges enrollees and the growth of higher education institutions in the USA. Consequently, a few decades later, liberal arts colleges and their departments, including music, multiplied exponentially, generating a disequilibrium in the market. Over the years, this unbalanced market has made the concert music performance career more demanding and aggressively selective.

Throughout the book's six chapters, the author argues persuasively that artistic integrity and entrepreneurship in music should coexist. By proffering personal stories, ideas, and tools to help aspiring concert music performer, particularly students, the author explains how entrepreneurship in a concert music career can work, inspiring a new mindset in today's musicians.

\section{The Musician's Mind: Teaching, Learning, and Performance in the Age of Brain Science,} by Lynn Helding (Rowman \& Littlefield, 2020).

Helding provides a comprehensive volume on mental well-being and cognitive abilities related to music performance. Helding, who serves as a professor in vocal arts and opera and as coordinator of voice pedagogy at the University of Southern California Thornton School of Music, as well as being associate editor of the Journal of Singing and the creator of that journal's "Mindful Voice" column, ${ }^{42}$ extensively investigated a wealth of

\footnotetext{
${ }^{41}$ Nytch (Preface, page ix).

${ }^{42}$ Short bio extracted from the back cover of the book.
} 
topics: the learning process in music, music cognition, the psychology of music, digital life and its use, motor learning, performance studies, and more subjects that would be unthinkable without current technologies.

Throughout eight chapters plus a Preface and Introduction, Helding focuses on cognition, specifically how humans learn. To better understand the context, the author explains the two pillars of investigation within the cognitive neuroscience of music: "Music and Emotion" and "The Perception and Cognition of the Musical Structures." To scrutinize these two pillars, Helding analyzed, among other secondary sources, the famous book on the topic, This is Your Brain on Music. ${ }^{43}$ This work has been used as a foil: Helding argues that the primary research reported by Levitin was conducted along a "one-way path." The recorded sound was "injected through the conduit of the human ear to its final destination, the human brain." ${ }^{44}$ Helding avers that, as a result of this process, researchers could collect information and infer how listening to music affects the brain. However, this process does not explain how the brain might influence the way we make music.

Using as polestar the question of "How the current state of brain science make us better musicians," Helding points out the vital difference between learning and performance. She defends the position that "their vital link is practice." By presenting (and often debunking) learning theories to enlighten the reader on how human cognition works, she offers clear and concise explanations of the most common learning processes used in music, such as declarative and procedural learning. Additionally, she approaches other theories and behaviors commonly applied by music performers, even when they are not aware (or entirely

\footnotetext{
${ }^{43}$ Daniel J. Levitin: This Is Your Brain on Music: The Science of a Human Obsession. New York, N.Y.: Dutton, 2006.

${ }^{44}$ Lynn Helding: The Musician's Mind: Teaching, Learning, and Performance in the Age of Brain Science, $\mathrm{p}$. xxi.
} 
aware) of this process, such as motor learning, theory of attentional focus, deliberate practice, desirable difficulties, and performance anxiety.

Helding concludes by examining current issues faced by modern performers. She expatiates on the digital era and the digital media, especially how these elements have undermined our attention, memory, and social interaction. Additionally, in the very last chapter, the "Coda Section," the author shares her thoughts on how The Fourth Culture ${ }^{45}$ can contribute to expanding the boundaries between science and arts.

Be Your Own Manager: A Career Handbookfor Classical Musicians, by Bernhard Kerres and Bettina Mehne (Tenaia Management Ltd., 2017).

This is a straightforward book with a self-explanatory title. The authors, both of them accomplished artists and entrepreneurs, precisely and concisely describe and teach classical musicians' paths to achieve and establish a professional career. According to the authors, the book aims to cover all critical aspects for the self-management of classical musicians.

Therefore, it should be used as a career handbook for "classical" instrumentalists, singers, conductors, and others making this music their profession. The basics of understanding the industry's business side, marketing, social media, fee negotiations, and time management for both young and experienced classical musicians are addressed by authors with wisdom and perspective. Organized in eighteen chapters, every portion includes practical examples to make it both easily understandable and implementable.

\footnotetext{
${ }^{45}$ Fourth Culture is a term coined by American writer and neuroscientist Jonah Lehrer. He poses the need for a "Fourth Culture where science would concede that not everything can be known and would welcome a place for the arts." The original concept was conceived by the British scientist and novelist C.P. Snow. In his famous lecture, later published in book form as The Two Cultures and The Scientific Revolution (1959), Snow defended that science and the humanities which represented "the intellectual life of the whole of western society" had become split into "two cultures," and that this division was a major handicap to both in solving the world's problems. Decades later, John Brockman, president of the Edge Foundation, writer, and literary agent, coined the term "Third Culture." According to Brockman, the "Third Culture consists of those scientists and other thinkers in the empirical world who, through their work and expository writing, are taking the place of the traditional intellectual in rendering visible the deeper meanings of our lives, redefining who and what we are."
} 
Bernhard Kerres, an opera singer, and the founder of HELLO STAGE, the "LinkedIn for classical musicians," and Bettina Mehne, former Artistic Manager of The Deutsche Kammerphilharmonie Bremen and former Head of Artistic Planning at the Wiener Konzerthaus, start the book with a discussion on what makes a musician special and distinctive, and how to communicate that presence. An important topic explored in this book is the careful attention given to a key element in the $21^{\text {st }}$ century: the digital presence. Kerres and Betina include website tips and other suggestions on how to build a professional image in the virtual world.

Beyond Talent: Creating A Successful Career in Music, by Angela Myles Beeching (Oxford University Press, 2010, $2^{\text {nd }}$ ed.).

This book, now in its third edition (discussed below), has been considered a "classic" by experts in the music career development field. Beeching is a music career coach who teaches musicians how to get more of their best work out into the world, so they can finally become the artists they are meant to be. A leader in the field of music career development, she is the former director of career and entrepreneurship programs at Manhattan School of Music, Indiana University, and New England Conservatory. ${ }^{46}$

Beyond Talent is both one of the pioneering books in its field and also one of the most comprehensive books related to music performance career written so far in the $21^{\text {st }}$ century. Organized in thirteen chapters plus a "Postlude" section, Beeching covers a wealth of subjects, from developing and sustaining a meaningful life in music to social networking, commissioning, and artistic tools. Thus, the book works as an ideal companion for students and professionals, emerging musicians, and mid-career artists.

\footnotetext{
${ }^{46}$ Short bio extracted from the book.
} 
The third edition of this book was released in 2020. Although the edition analyzed in this document ( $2^{\text {nd }}$ edition) provides a substantial range of tools, the $3^{\text {rd }}$ edition brings further advice and tools on fear, uncertainty, and self-doubts. ${ }^{47}$ Comparing the last two editions, we can notice that author has focused more on mindset issues and its consequences. Since the topics germane to this study were carried over from the previous edition, as well as for reasons of limiting the time-frame encompassed by this main bibliography, this review focused addressed the $2^{\text {nd }}$ edition.

Teaching Music in Higher Education, by Colleen M. Conway and Thomas M. Hodgman (Oxford University Press, 2009).

This book was designed for faculty and graduate assistants working with undergraduate music majors and non-majors in colleges and universities. Colleen Conway is Professor of Music Education and Vice-Chair of the Faculty Senate at The University of Michigan. She holds bachelor's and master's degrees in horn performance and music education from the Eastman School of Music, and a doctorate in music education from Teachers College, Columbia University. Thomas M. Hodgman is Associate Professor of Music and Chair of the Music Department at Adrian College. ${ }^{48}$

The book comprises thirteen chapters, organized into three "macro parts," and invests a significant portion of its attention to undergraduate music curricula and their peculiarities. First, the author thoroughly introduces and guides the reader through the National Association of School of Music requirements. Conway and Hodgman cover subjects from assessments and gradings in music courses, syllabus design, lessons, and applied studio

\footnotetext{
${ }^{47}$ Information extracted and transcribed from a promotional video recorded by the author of the book on her website. https://angelabeeching.com/book/

${ }^{48}$ Short bio extracted from The University of Michigan School of Music Faculty Profiles and from the back cover of the book. https://smtd.umich.edu/about/faculty-profiles/colleen-m-conway/
} 
teaching to meaningful insights on the job search in higher education and academic career management.

The second edition was published in 2020. According to the editor, it brings five newly written chapters and sizable additions, including gender identity, sexual identity, and issues of cultural diversity not addressed in the $1^{\text {st }}$ edition. Conway also covers technology in instructional settings and includes new references and updated student vignettes. Although all new subjects covered in the most recent edition are valuable and have an important role in current academia, in light of the inclusion of this book as required reading in the courses introduced later in this document, instructors must consider the significant difference of price between the first and second edition. Since the main topics relevant to this study were covered in the $1^{\text {st }}$ edition, this edition was reviewed here.

\section{The Savvy Musician: Building a Career, Earning a Living, \& Making a Difference, by}

David Cutler (Helius Press, 2010).

This book brings insightful and realistic perspectives on the music career field. Cutler, Coordinator of Music Entrepreneurship Studies at Duquesne University, summarized in this book what all concert musicians, particularly freelancers, should learn in order to establish a career in the real world of concert music performance.

This statement outlines the goals of the book:

The professional marketplace is flooded with outstanding musicians, forced to compete for a shrinking number of "traditional" opportunities. The Savvy Musician helps balance three overriding aspects of your professional musical life: (1) building a career, (2) earning a living, and (3) making a difference.

Throughout the fourteen chapters of this book plus four Appendixes, Cutler designs a contemporary and practical "roadmap," covering topics ranging from talent and technical 
skills, career issues, and finances to ideas on creating and leaving a legacy in the music world.

As the back cover expounds, "Besides his academic career, Cutler balances a varied career as a jazz and classical composer, pianist, educator, arranger, conductor, collaborator, concert producer, author, blogger, consultant, speaker, advocate, and entrepreneur. In all these pursuits, he works to push boundaries while connecting with new audiences." 49

The Orchestra: A Very Short Introduction, by D. Kern Holoman (Oxford University Press, 2012).

This book was conceived to be part of Oxford University Press's well-known Very Short Introductions series and brings a concise but meaningful and profound overview of the world of orchestras. This volume provides an authoritative and engaging assessment of the orchestral environment's history, concept, and work. Given the historically central role of the orchestra in concert music life, this book provides valuable insights into the topics at hand.

D. Kern Holoman, a Distinguished Professor of Music at the University of California, Davis, and conductor emeritus of the UC Davis Symphony Orchestra, starts his book by recounting the historical journey of European ensembles and musicians until the advent of the Philharmonic Societies, arguing that these institutions were crucial to the birth and establishment of the modern orchestra. According to the editors, "[Holoman] explores topics ranging from the life of a musician in a modern orchestra, the recent wave of new hall construction from Berlin to Birmingham, threats of bankruptcies and strikes, and the eyebrow-raising salaries of conductors and general managers. At the heart of the book lies a

\footnotetext{
${ }^{49}$ Short bio extracted from the back cover of the book.
} 
troubling pair of questions: Can such a seemingly anachronistic organization long survive? Does the symphony matter in contemporary culture? "50

With nine chapters plus a conclusion, the book addresses notable topics and pertinent issues related to the world of the orchestra. Note that the author is oriented toward European and especially American orchestras' and musicians' issues, ignoring all orchestral development in other parts of the world.

Practicing Music by Design: Historic Virtuosi on Peak Performance, by Christopher Berg (Routledge, 2019).

In this book, Christopher Berg explores pedagogical practices for achieving expert skill in performance. This extensive investigation by analyzes and examines the defining characteristics and applications of eight common components of practice from the perspectives of performing artists, master teachers, and scientists. Berg, a Carolina Distinguished Professor at the University of South Carolina School of Music, wants to help musicians understand the abstract principles behind the concepts, allowing them to identify areas in their practice that prevent them from developing. By scrutinizing old teaching methodologies, Berg breaks down some fallacies and myths, such as the It-Works-for-Me Fallacy, providing interesting information about technical skills development and mental work, including the memorization processes.

Organized in ten chapters, with numerous examples and exercises, the author presents well-structured activities and insights to help students and professionals to establish healthy and wise practice routines.

\footnotetext{
${ }^{50}$ D. Kern. Holoman: The Orchestra: A Very Short Introduction. A Very Short Introduction. Oxford: Oxford University Press, 2012, front cover endorsement.
} 
The nine books reviewed above offer an eclectic bibliography and portray the holistic educational perspective defended by this document. When compared to even the recent past, the context in which we find ourselves - that of the Fourth Industrial Revolutiondemonstrates the benefit for today's musicians derived from honing skills that include critical thinking, creativity, collaboration, communication, information literacy, media literacy, technology literacy, flexibility, leadership, initiative, self-promotion, marketing, teaching skills, performance skills, productivity, and social skills. These must therefore be fully integrated into their training.

\section{The Curricular Structure and its Contents}

We now offer an overview of proposed courses and their structured sample syllabi, with a discussion of possible alternatives for programs and departments where the implementation of these courses is not feasible. The books referenced above and the further readings cited in the sample syllabi section can be used by instructors and practitioners as a starting point to support the courses and subjects to be covered.

This material can be fruitfully organized by highlighting a few topics. To help us address the aforementioned professional demands of the current century, we must learn management skills: how to manage ourselves and, consequently, our professional careers. Similar to entrepreneurial subjects, music technology also has become a "hot" subject in academia. Although practical performance courses represent among the lowest percentage of classifications in the eight meta-topic chart, when practical performance is studied, it seems advisable for its relationship to this proposed curriculum to be strengthened to the extent that performance studies, too, embrace the undergirding principle of innovation. After all, music performance is the main reason why our craft is still surviving. Performance is the visible part 
of the whole music-making process, and we benefit from transforming our understanding of performance in accordance with present demands.

Therefore, despite the strong emphasis on instrumental technique and music-related subjects in graduate-level curricula, today's performers must be innovative and proactive due to the high level of competition. Whereas in the past, performers of concert music could have a "Fordist mindset" and wait for the right opportunity, today's musicians need to adapt to the cultural demands or to develop different skills quicker. The over-crowded market forces us to be innovative.

What, then, would become of the current graduate core curriculum? In order to place at the center of the curriculum the courses designed for this document and its subjects (see Appendix A), which address specific current pedagogical and professional demands, the current typical core curriculum for graduate study in music performance in the U.S. (i.e., music analysis, musicology, and bibliography and research) would become electives. In effect, the relationship of coursework other than applied study would be inverted. In some environments, this is admittedly an ambitious—some might say, utopian—project. Nevertheless, there are countries where this curricular structure might be feasible. At the same time, the author of this paper recognizes that implementing this curriculum in certain cultures including the United States might not be possible in some higher education institutions due to several pedagogical, structural, and financial reasons. Alternatives are discussed below.

This language can be understood to conform to language used by NASM. Considering the curricular structure and requirements for graduate studies by NASM and its definition of professional work in music specializations, the proposed curriculum would cover and 
contribute directly to the artistic and scholarly development of $21^{\text {st }}$-century graduate students.

The NASM Handbook states that:

Professional work in music specializations is produced through creative endeavor, inquiry, and investigation. Each type of work and each individual work exhibits specific intent, content, methodology, and product. Individual or group decisions about these four elements shape the ways that creativity, inquiry, and investigation are used to produce work in various artistic, scholarly, pedagogical, or other specializations. Competency to practice in one or more fields of specialization includes the ability to conduct the types of creative work, inquiry, and investigation normally associated with the specialization(s) chosen. ${ }^{51}$

As we can see above, NASM suggests that creativity, inquiry, and investigation are key elements in music specialization. Since graduate studies is about developing professional skills at the highest level, the elements just above mentioned, and their concepts, are profoundly related to the topic of this paper. The author of this document understands that such elements might be present in the curricular structure of the majority of the institutions, but they might not be explicitly presented, introduced, and explored in the core curricula of many schools and conservatories worldwide. ${ }^{52}$

There remains one additional area that would be beneficial to add to the core graduate performance curriculum. The common sensibility concerning graduate studies in the U.S. and in other countries suggests that these degrees, particularly terminal degrees, aim to prepare academically those musicians for pursuing a career in higher education. While the candidate might have other, personal reasons to obtain the highest academic degree, these personal reasons for pursuing graduate degrees cannot reasonably include achieving eligibility for jobs: other careers in music, especially performing positions, do not require terminal degrees. It is therefore appropriate for a graduate curriculum to include coursework on pedagogy.

\footnotetext{
${ }^{51}$ NASM Handbook 2020-21 (Section X - Graduate Programs in Music - item 4, page 127).

${ }^{52}$ According to NASM Handbook, graduate students must gain knowledge and skills in one or more fields of music outside the major such as theory and analysis, history and literature, musicology and ethnomusicology, and pedagogy. Such supportive studies in music that broaden and deepen musical competence comprise at least one-third of the total curriculum. NASM Handbook 2020-21 (Section XIV.B - Graduate Programs in Music Master's Degree in Performance - item 6 - b, page 134).
} 
To expand on this, the author has observed a considerable number of graduate students and young college teachers in the U.S. and abroad landing in higher education jobs without knowing how academia works pedagogically and administratively. Moreover, it should be noted that NASM considers pedagogical training in graduate studies sufficiently important to include it in its requirements. However, such requirements are not part of the core curriculum. It seems like a conundrum: graduate programs in music performance are expected to prepare artists to teach and work in the academic environment, but such training is not demanded in the core curriculum.

Considering that students in terminal degrees intend to pursue an academic career, classes such as music theory and music history, especially for doctoral students, could be taught based on the pedagogical teaching of these subjects, e.g., music theory pedagogy and music history pedagogy. Thus, graduate students would have the opportunity to update their knowledge. In addition, they would be able to acquire pedagogical skills to teach these classes in an eventual job opportunity.

By providing the designed courses below, this paper proposes an "ideal music curriculum" for the third decade of the $21^{\text {st }}$ century. Schools of music and conservatories where professional music performance training is the primary goal might find substantial benefits in including these courses, syllabi, and bibliographies into their curricular structure. Additionally, professional musicians can extract important concepts and reflections from these materials to incorporate them into their careers. However, this material could be studied in other venues as well.

Due to the heterogeneity of the level of the students and music institutions in the United States, subjects considered essential in one institution might not be perceived the same way in another institution, resulting in different pedagogical outcomes. For example, many 
schools require music theory review and music history classes to bring the graduate students to the same level to minimize these curricular dissimilarities. In such a setting, one viable path forward could be to offer these contents from a different perspective.

In such situations, instructors can select, adapt, and apply specific contents from the proposed curriculum in courses already existent in the institution, such as studio classes, music convocation classes, applied lessons, and in other specific classes offered by the music department or program.

Specific topics can be addressed in an extra-curricular manner, such as by inviting guest artists and other professionals related to the field or subject to be covered. A school might offer, for example, a workshop on writing a c.v., another on artistic and academic professional life, or an office of career guidance in music with an officer who addresses topics by request.

It is also possible that some of these courses could be folded into an undergraduate curriculum. The full implications of this possibility are beyond the scope of this document but are well worth considering.

Expanding the scope of possibilities, courses that already engage with the topics recommended in this document, currently often categorized as special topics, could become part of a new area of study called "Professional Musicianship," and given a curricular status parallel to such well-established disciplines as analysis and musicology. Another possibility could be that these topics could become a group of " $21^{\text {st }}$ Century Electives Courses," offered on a rotating basis.

However, it is extremely important that these topics be addressed in a systematic and responsible manner. Students are not recommended to seek out the resources to educate 
themselves on these matters without faculty guidance. Without a proper introduction and mature guidance, they might feel confused or lost.

Thus, to offer practical pedagogical alternatives and strategies for instructors, professionals, and students, this paper proposes that the graduate study in music performance include a group of disciplines to prepare graduate students to the current needs of the present century. For the purposes of this document, this group of disciplines will be called Professional Musicianship, and these disciplines will be under the umbrella of Music Performance Studies. The author of this document has designed ten disciplines that could be included in the $21^{\text {st }}$-century music graduate study core curriculum.

Since the largest slice of the Eight Macro- Areas chart (figure 1) was the subject of career development and since this paper aims to offer an enhanced curriculum for music performance graduate students, this new curriculum will need to be subject to ongoing reexamination. Instructors are strongly advised to periodically search and analyze new needs and tendencies in the music performance field and in the related market. Thus, academia and the professional world would be permanently connected to prepare the prospective professionals accordingly.

In this document, Professional Musicianship disciplines will be categorized into two subtopics: Career Development and $21^{\text {st }}$ Century Performance Skills.

Career Development courses will cover topics related to navigating academia, music institutions and their organization, entrepreneurial skills, and other subjects related to management and growth in a career as a concert music performer. $21^{\text {st }}$ Century Performance Skills will cover performance practices subjects, pedagogical approaches that consider the current cultural moment and its available technological resources, and the science, 
psychology, and wellness topics that are most closely related to the music performance practices.

Below, we can briefly see a summary of the subjects to be further explored in the Sample Syllabi section.

Career Development - These courses are designed to teach music performance students to:

- devise plans to integrate artistic career and entrepreneurial knowledge, and to explore further the music performance career field and its bountiful possibilities in the current century;

- acquire and develop pedagogical, mentorship, and administrative skills to pursue an academic career in the U.S., considering the current curricular and cultural agenda;

- equip orchestral students, especially conducting students, with the knowledge and perspective needed to succeed as professional orchestral musicians, including both players and conductors, in a changing industry;

- build and manage a career both artistically and administratively.

$21^{\text {st }}$ Century Performances Skills - These courses are designed to teach music performance students to:

- develop academic perspectives on creativity and artistry in teaching and performance, considering the standard and innovative approaches;

- incorporate technology into their teaching methodologies and performances;

- integrate science, psychology, and wellness into Music Performance Studies.

The proposed curriculum aims to provide a complete course of study for a graduate program in music performance only. As aforementioned, instructors should periodically 
reevaluate these topics. This proposed curriculum is a guide, to be reexamined and expanded throughout the years.

Below are possible disciplines (five courses per area) that graduate students and professional musicians might study in order to be more prepared to navigate $21^{\text {st }}$-century demands. For some of these courses, Appendix A provides more expanded treatment in the form of sample syllabi to guide instructors on how to approach or adapt the courses considering their specific needs and goals.

The two areas addressed are:

1. Career Development

2. $21^{\text {st }}$ Century Performance Skills

\section{Career Development ${ }^{53}$}

\section{Today's Musician 1: A Professional Guide for Music Performers}

This course is designed to teach music performance students to be prepared for a professional music career and its possibilities. It will help students examine long-term career prospects and devise a plan to integrate artistic career aspirations with supplementary or complementary employment.

Learning objectives: In this course, we will cover the following topics:

- fundamentals of job searching and the creation of employment application materials for a wide variety of artistic, non-artistic, and academic employment opportunities;

- entrepreneurship and business planning;

- exploration of nonprofit institutions.

- job interview training.

\footnotetext{
${ }^{53}$ The course descriptions in this section offer an overview of the proposed curriculum only. Detailed information such as contents, assignments, exercises, academic calendar, readings, and further readings, are available in the Appendix A Section - Sample Syllabi.
} 
Learning outcomes: By the end of this course, the student should be able to:

- develop their own professional portfolio and ePortfolio;

- design CV, resumes, and statements;

- formulate their projected professional goals considering three different music career alternatives;

- design an artistic "Five-year" career plan.

\section{Today's Musician 2: A Professional Guide for College Professors}

This course is designed to teach music performance students to be prepared for the professional music career and its possibilities. "Today's Musician 2: A Professional Guide" is designed for performers who aspire to pursue an academic career. It will help students examine long-term career prospects and devise a plan to integrate artistic career aspirations with supplementary or complementary employment.

Learning objectives: In this course, we will cover the following topics:

- academia and its organizational structure;

- notions of music school administration;

- NASM requirements;

- music performance curricula;

- strategies to build an academic career plan;

- academic counseling and mentorship;

- job interview training.

Learning outcomes: By the end of this course, the student should be able to:

- understand the academic career and its processes;

- design a tenure-track plan; 
- advise and mentor students;

- design course descriptions and syllabi;

- teamwork and leadership;

- create and design music performance curricula.

\section{Orchestral Entrepreneurship}

This course is designed to equip orchestral students, especially conducting students, with the knowledge and perspective needed to succeed as professional orchestral musicians, including both players and conductors, in a changing industry. The class covers essential organizational, financial, and programmatic issues affecting orchestras and their entrepreneurial possibilities for the future. Includes guest speakers from the League of American Orchestras, American Federation of Musicians Symphonic Services Division (the Union), and others.

Learning objectives: In this course, we will cover the following topics:

- American orchestras: History and Organizational structures;

- notions of orchestra management;

- union, leagues, and associations;

- boards, committees, and sponsors;

- audition processes for musicians and conductors;

- repertoire and seasons;

- budget and marketing.

Learning outcomes: By the end of this course, the student should be able to:

- understand the role of musicians and their conductors in large ensembles, and the developing role of these ensembles in the $21^{\text {st }}$ century;

- develop plans to reach out to the community, sponsors, and other stakeholders; 
- critically design a concert season considering the current cultural moment; ${ }^{54}$

- create and be part of an orchestra committee and board of directors - for conductors, understand the agendas of such bodies and productive strategies of interaction;

- coordinate conductor searches - for conductors, understand the range of goals of a conductor search committee.

\section{Music, Gigs, and Money Seminar}

This course is designed to cover topics such as taxes, ensemble budget, writing national and international grants, creating fundraisers, and designing and presenting projects to sponsors.

Learning objectives: In this course, we will cover the following topics:

- types of forms and how to fill them out;

- national and international grants: Where to find them? How to apply?;

- types of sponsorships;

- mock project presentations.

Learning outcomes: By the end of this course, the student should be able to:

- fill out forms and taxes accordingly;

- $\quad$ prepare and organize a budget for projects;

- identify and apply for national and international grants;

- $\quad$ prepare and present projects to sponsors such as companies, patrons, and general media.

\footnotetext{
${ }^{54}$ It is important to clarify here that the study of programming a concert/recital/season is a study in addressing different audiences, the cultural crossroads, and balancing different repertoires. For example, in this third decade of the $21^{\text {st }}$ century, the study of programming has obvious intersections with such concerns as Black Lives Matter, BIPOC repertoire, GLBTQ+ composers. However, it is important to ponder that the current cultural discussions cannot obliterate the received "standard repertoire." Students therefore need to be exposed to a variety of works to develop a solid understanding of how to design a concert season accordingly.
} 


\section{Chamber Music Management}

This course is designed to teach students how to manage small chamber music groups. How to develop a concert season, programming ideas, concert series, and promotion techniques.

Learning objectives: In this course, we will cover the following topics:

- chamber music in the $21^{\text {st }}$ century: what has changed?;

- marketing: do's and don'ts;

- repertoires and outfits;

- communication skills;

- coaching methodologies;

- long-term projects.

Learning outcomes: By the end of this course, the student should be able to:

- develop a concert season according to the $21^{\text {st }}$ century expectations;

- manage chamber music ensembles;

- design a long-term project for chamber groups;

- understand, describe, and demonstrate initiative and leadership;

- critically design a concert season considering the current cultural moment;

- research repertoire and create concert seasons. 


\section{$\underline{21^{\text {st }} \text { Century Performance Skills }}{ }^{55}$}

\section{Science and Psychology of Music Performance}

This course is designed to present sport psychology methods to help students achieve optimal performance levels under the pressure of juries, recitals, competitions, and auditions. Students will learn how to deal with fear and doubts, channel nervousness, focus better, and perform at a high level in stressful situations.

Learning objectives: In this course, we will cover the following topics:

- performance skills profile;

- exercises and mock auditions;

- music cognition;

- deep practice;

- memorization;

- body movement;

- $\quad$ self-esteem theory;

- mental rehearsal.

Learning outcomes: By the end of this course, the students should be able to:

- develop practical exercises to manage performance anxiety;

- establish strategies and techniques to enhance their practice routines;

- identify pitfall thoughts and mental strengths;

- understand how music psychology and music cognition help in daily practices;

\footnotetext{
${ }^{55}$ The course descriptions in this section offer an overview of the proposed curriculum only. Detailed information such as contents, assignments, exercises, academic calendar, readings, and further readings, are available in the Appendix A Section - Sample Syllabi.
} 
- develop personal mechanisms to fight back against negative thoughts during performances;

- develop and demonstrate more confidence on stage.

\section{Creative Performance Laboratory}

In this course, students will be required to create and video-record three different interpretative versions of the pieces or method books they will be working on during the semester. In addition, the instructor will guide the students in approaching different music styles and genres and helping them to design a program of studies to develop their projects.

Learning objectives: In this course, we will cover the following topics:

- how to define an artist;

- creativity and its processes;

- styles in classical music: then and now;

- $\quad$ musical text and its context;

- organology: instruments and their limitations.

Learning outcomes: By the end of this course, the students should be able to:

- investigate and create scholarly versions of their repertoire;

- understand the current role of the artist and how it differs from former models;

- explain different ways to understand creativity;

- discuss and demonstrate initiative and leadership;

- understand and implement teamwork and communication;

- develop and perform a unique interpretation of a piece of music. 


\section{The Digital Performer}

This course is designed to introduce basic skills demanded by online teaching and performance.

Students will be become technically familiarized with music notation software, recording techniques, popular video and audio platforms, such as Zoom, YouTube, Skype, and social media, and learn how to explore all its resources technically. The final assignment will require an online recital.

The final assignment will require an online recital.

Learning objectives: In this course, we will cover the following topics:

- types of microphones and microphone adjustments;

- recording devices setup;

- lighting;

- live stream platform and software;

- social media rules;

- online performances and monetization;

- how music apps can improve and enhance our daily practice;

- how specific apps and software are designed and their goals.

Learning outcomes: By the end of this course, the student should be able to:

- use technically video platforms and social media and its resources ${ }^{56}$;

- $\quad$ setup and adjust teleconferencing software and streaming platforms;

\footnotetext{
${ }^{56}$ This includes software, gadgets, and devices system requirements and their compatibility with the platforms and social media to be used in this course.
} 
- create and manage online events and different streaming services;

- create professional-looking scores for many ensembles;

- turn manuscript scores into digital scores for small and large orchestras;

- edit and extract parts from a score in a proper format;

- create simulated performances using MIDI;

- demonstrate an appropriate level of media literacy;

- demonstrate an appropriate level of technology literacy.

\section{Recital-Spectacle Laboratory}

This class will stimulate music performance students to create recitals in unconventional formats. Students will collaborate with creative arts, acting, production, journalism, and marketing graduate students to elaborate and develop innovative ways to prepare, perform, and promote their concerts. Guided by a team of instructors from different fields, students will explore the goals mentioned above and develop strategies to reach out and create connections between the audience and students.

Learning objectives: In this course, we will cover the following topics:

- beyond the music: the recital's goals;

- teamwork skills;

- audience and repertoire: strategies to engage the audience;

- outfits and venues.

Learning outcomes: By the end of this course, the students should be able to:

- identify current best practices for reaching out to their audience; 
- create innovative concert programs;

- understand all basic steps in music production;

- understand and demonstrate basic principles of effective communication;

- understand and demonstrate basic principles of effective collaboration;

- understand and demonstrate basic principles of effective social skills;

- demonstrate an artistic stage presence.

\section{Performance and Wellness}

This course is designed to increase the awareness of the need for physical and mental health in the performance career. Although most of the injuries related to music career might be prevented, a significant number of music students and professionals still cope with health issues associated with physical overuse, mental fatigue, and performance anxiety. This course intends to offer tools to develop and cultivate healthy practicing and performance habits, thus helping to prevent life-changing injuries.

Learning objectives: In this course, we will cover the following topics:

- develop awareness of a healthy practice routine;

- understand main issues related to body and mind in music, and prevention of injuries;

- develop and improve teaching skills to help future students;

- further the discussion on musician's health and wellness.

Learning outcomes: By the end of this course, the students should be able to:

- understand the importance of a healthy music career;

- develop a better understanding of how the body works and the value of respecting its limits;

- demonstrate critical thinking on High-Performance concepts. 


\section{Conclusion}

In the quest to understand the evolutionary process of the music performance studies, it is crucial to comprehend the origins and development of this field; only then can one hope to successfully explore and design new paths to the present and to the future.

After analyzing one of the first European state music institution of the modern era, the Conservatoire de Paris, and the top-five music institutions in the U.S., selected according to Kushwaha's article, we can conclude that the top-five institutions share a similar core curriculum structure, resembling the structure curricular designed in 1795 for the French conservatory. These similarities prompt this document to reflect on the manner in which the music core curriculum of the current and future music performers is still structured.

As a first reflection, the author understands that the art of the music, even considering music works conceived centuries ago, will now be listened to and evaluated by people living in the present moment. For the standpoint of reaching one's audience, this can be concerning: concepts and ideas change over time and, as cultural expectations shift, older cultural values can become stale and outworn. For this reason, classical musicians benefit from embracing all current cultural, educational, and technological resources to better communicate with the audience, and to establish a meaningful and permanent role in their communities and in the society as a whole.

Consequently, as a second reflection, to achieve the goal above mentioned, these remarks and discussions must be furthered in the places where knowledge is produced: in academia. This is already underway: indeed, the institutions analyzed in section II have explored academic alternatives to broaden the student's possibilities by offering a variety of academic courses that address the current demands of the $21^{\text {st }}$ century mentioned in this document. Notwithstanding, this author concludes that such variety of disciplines and 
subjects that are currently on offer are not enough. Moreover, we need more than an alternative or an elective option. To impart new ideas and thoughts on this matter, the root, i.e., the core curriculum, must be reexamined and adapted accordingly. Ergo, the change must be structural to be effective.

To conclude, while this document has been written, the world faces a global pandemic in 2020-2021. Unnumbered freelance musicians worldwide had to cope with cancellations of concerts, gigs, and private lessons. To avert deficit, well-established orchestras and other professional ensembles had to renegotiate salaries, cut benefits, or even furlough their employees in order to save institutions. Many college professors had to become well-versed in technologies (several already existent) to maintain their academic activities.

Such a scenario and its consequences for the world after Covid-19 pandemic compels this author to believe that it is necessary to rethink the future of the career of music performance by exploring, expanding, and re-signifying its possibilities. This writer firmly believes that a contemporary professional perspective toward a new curricular agenda for graduate study in music performance is imperative to further address the role of the musicians in our society, and better prepare the prospective music students and professional musicians for the $21^{\text {st }}$ century. 


\section{Bibliography}

\section{$\underline{\text { Section } 1}$}

\section{Books}

Bibonne, François. "La formation des pianistes du Conservatoire national supérieur de musique et de danse de Paris: (1991-2018).” Dissertation, Hal - archives-ouvertes.fr, 2018. https://dumas.ccsd.cnrs.fr/dumas-01916616/document.

Eco, Umberto. How to Write a Thesis. Translated by Caterina Mongiat Farina and Geoff Farina. Cambridge, MA: MIT Press, 2015.

Grandville, Frédéric de la. Une histoire du piano: Au Conservatoire De Musique De Paris 1795-1850. Kindle Edition. Paris: L'Harmattan, 2014.

Heile, Björn, Rodriguez, Eva Moreda, and Stanley, Jane, eds. Higher Education in Music in the Twenty-First Century. London: Routledge, 2016. Accessed April 2, 2019. ProQuest Ebook Central.

Holoman, D. Kern. "The Paris Conservatoire in the Nineteenth Century." Oxford Handbooks Online, 2015. doi:10.1093/oxfordhb/9780199935321.013.114.

Pierre, Constant. Bernard Sarrette et les Origines du Conservatoire National de Musique et de Déclamation, Paris, Delalain, 1895.

Rugiu, Antonio Santoni. Nostalgia do Mestre Artesão. Campinas, SP: Autores Associados, 1998.

\section{Articles}

Benneth, Joseph. "The Origin of the French Conservatoire." The Musical Times and Singing Class Circular 31, no. 569 (1890): 393-95. https://doi.org/10.2307/3364508.

Kushwaha, Ayushi. "Best Music Schools in the World For 2019." CEOWORLD Magazine. March 23, 2019. Accessed April 04, 2019. https://ceoworld.biz/2019/03/23/bestmusic-schools-in-the-world-for-2019/.

Rubinoff, Kailan R. "Revolutionizing Nineteenth-Century Flute Technique: HugotWunderlich's Méthode de Flûte (1804): Part I.” Traverso 22, no. 1 (January 2010). http://traversonewsletter.org

--- "Toward a Revolutionary Model of Music Pedagogy: The Paris Conservatoire, Hugot and Wunderlich's Méthode de flûte, and the Disciplining of the Musician." Journal of 
Musicology 1 October 2017; 34 (4): 473-514. doi: https://doi-

org.wvu.idm.oclc.org/10.1525/jm.2017.34.4.473

\section{Section II}

\section{Websites}

\section{Boston Conservatory}

https://bostonconservatory.berklee.edu/sites/default/files/d7/bcb/MM\%20Woodwind.pdf

\section{Juilliard School}

https://catalog.juilliard.edu/preview_program.php?catoid=47\&poid=4293\&returnto=5297

\section{Manhattan School of Music}

https://3fv92513fnvf2m1ou93dy4td-wpengine.netdna-ssl.com/wp

content/uploads/2021/02/20-21-Course-Catalog-Feb-19-2021-Update.pdf

\section{New England Conservatory}

https://necmusic.edu/sites/default/files/documents/2020

2021\%20Academic\%20Catalog_0.pdf

Yale School of Music

https://bulletin.yale.edu/sites/default/files/school-of-music-2018-2019.pdf

\section{Section III}

\section{Books}

Ayer, Julie. More Than Meets the Ear: How Symphony Musicians Made Labor History. Kindle version. Minneapolis: Syren Book, 2005.

Bain, Ken. Super Courses: The Future of Teaching and Learning. Princeton, NJ: Princeton University Press, 2021.

Blanning, T. C. W. The Triumph of Music: The Rise of Composers, Musicians and Their Art. Cambridge, Mass.: Harvard University Press, 2008.

Beeching, Angela Myles. Beyond Talent: Creating a Successful Career in Music. $2^{\text {nd }}$ ed. New York: Oxford University Press, 2010.

Berg, Christopher. Practicing Music by Design: Historic Virtuosi on Peak Performance. New York: Routledge, 2019. 
Conway, Colleen Marie, and Thomas M Hodgman. Teaching Music in Higher Education. New York: Oxford University Press, 2009.

Cook, Perry R, and Perry R Cook. Music, Cognition, and Computerized Sound: An Introduction to Psychoacoustics. Cambridge, Mass.: MIT Press, 1999.

Cutler, David. The Savvy Musician: Building a Career, Earning a Living \&amp; Making a Difference. Pittsburgh, PA: Helius Press, 2010.

Eagleton, Terry. The Idea of Culture. Blackwell Manifestos. Malden, MA: Blackwell, 2000.

Eisner, Elliot W. The Arts and the Creation of Mind. [New Haven]:Yale University Press, 2002.

Gleason, Nancy W. Higher Education in the Era of the Fourth Industrial Revolution. Kindle Edition. Springer, Singapore: Yale-NUS College, 2018.

Hallam, Susan, Ian Cross, and Michael Thaut, eds. The Oxford Handbook of Music Psychology. $1^{\text {st }}$.ed. Oxford: Oxford University Press, 2011.

Harari, Yuval N. 21 Lessons for the 21st Century. $1^{\text {st }}$ ed. New York: Spiegel \& Grau, 2018.

Harrison, Scott D, ed. Research and Research Education in Music Performance and Pedagogy. Landscapes, Volume 11. Kindle Edition. Dordrecht: Springer, 2014.

Helding, Lynn. The Musician's Mind: Teaching, Learning, and Performance in the Age of Brain Science. Lanham, MD: Rowman \& Littlefield, 2020.

Holoman, D. Kern. The Orchestra: A Very Short Introduction. Oxford: Oxford University Press, 2012.

Honing, Henkjan. Musical Cognition: A Science of Listening. $3^{\text {rd }}$ Ed. New York: Routledge, 2017.

Honing, Henkjan, ed. The Origins of Musicality. Cambridge, MA: MIT Press, 2018.

Kerres, Bernhard, and Bettina Mehne. Be Your Own Manager: A Career Handbook for Classical Musicians. London: Tenaia Management, 2017.

Kivy, Peter. Sound Sentiment: An Essay on the Musical Emotions, Including the Complete Text of the Corded Shell. The Arts and Their Philosophies. Philadelphia: Temple University Press, 1989.

Klickstein, Gerald. The Musician's Way: A Guide to Practice, Performance, and 
Wellness. Oxford: Oxford University Press, 2009.

Koren, Leonard. What Artists Do. Point Reyes, CA: Imperfect Publishing, 2018.

Levitin, Daniel J. This Is Your Brain on Music: The Science of a Human Obsession. New York: Dutton, 2006.

McConnell, Christy, Bradley Conrad, P. Bruce Uhrmacher, and Jacqueline Grennon Brooks. Lesson Planning with Purpose: Five Approaches to Curriculum Design. New York: Teachers College Press, 2020.

Miller, Toby. Blow Up the Humanities. Philadelphia: Temple University Press, 2012.

Nytch, Jeffrey. The Entrepreneurial Muse: Inspiring Your Career in Classical Music. New York, NY: Oxford University Press, 2018.

Rabideau, Mark. Creating the Revolutionary Artist Entrepreneurship for the $21^{\text {st }}$ Century Musician. Lanham: Rowman \& Littlefield, 2018.

Ruyter, Alex de, and Martyn Brown. The Gig Economy. The Economy Key Ideas. Newcastle, U.K.: Agenda Publishing, 2019.

Sacks, Oliver. Musicophilia: Tales of Music and the Brain. New York: Alfred A. Knopf, 2007.

Schwab, Klaus. The Fourth Industrial Revolution. First U.S. ed. New York: Crown Business, 2017.

Snow, C. P. The Two Cultures and the Scientific Revolution. The Rede Lecture, 1959. Mansfield Center, CT: Martino Publishing, 2013.

Stepniak, Michael, and Peter Sirotin. Beyond the Conservatory Model: Reimagining Classical Music Performance Training in Higher Education. Cms Emerging Fields in Music. New York, NY: Routledge, 2020.

\section{Articles}

Bangert, Daniel, Emery Schubert, and Dorottya Fabian. "Practice Thoughts and Performance Action: Observing Processes of Musical Decision-Making." Music Performance Research 7, no. 1 (January 2015): 27-46. https://search-ebscohostcom.wvu.idm.oclc.org/login. aspx ?direct=true $\& d b=a 9 h \& A N=109282852 \&$ site=ehostlive \&scope=site. 
Bernhard, Christian. 2010. "A Survey of Burnout among College Music Majors: A Replication.” Music Performance Research 3 (June): 31-41. https://search-ebscohostcom.wvu.idm.oclc.org/login. aspx .direct $=$ true $\& d b=a 9 h \& A N=51366532 \&$ site $=$ ehostlive\&scope $=$ site.

Bowen, José Antonio. "Performance Practice Versus Performance Analysis: Why Should Performers Study Performance," Performance Practice Review: Vol. 9: No. 1 (1996) Article 3. DOI: 10.5642/perfpr.199609.01.03 http://scholarship.claremont.edu/ppr/vol9/iss 1/3

Dobson, Melissa C. 2010. "Performing Your Self? Autonomy and Self-Expression in the Work of Jazz Musicians and Classical String Players." Music Performance Research 3 (June): 42-60. https://search-ebscohost com.wvu.idm.oclc.org/login. aspx?direct=true $\& d b=a 9 h \& A N=51366534 \&$ site $=$ ehostlive \&scope $=$ site.-

Dogantan-Dack, Mine. "The Art Research in Live Music Performance." Music Performance Research 5 (2012 Special Issue 2012): 34-48. https://search-ebscohostcom.wvu.idm.oclc.org/login. aspx?direct=true \&db=a9h\&AN=90596169\&site=ehostlive $\&$ scope $=$ site.

Dolan, David, John Sloboda, Henrik Jeldtoft Jensen, Björn Crüts, and Eugene Feygelson. "The Improvisatory Approach to Classical Music Performance: An Empirical Investigation into Its Characteristics and Impact.” Music Performance Research 6 (January 2013): 1-38. https://search-ebscohostcom.wvu.idm.oclc.org/login.aspx?direct=true $\& d b=a 9 h \& A N=94899249 \&$ site $=$ ehost live \&scope $=$ site.

Drewe, Sheryle Bergmann. "An Examination of the Relationship between Coaching and Teaching." Quest 52, no. 1 (2000): 79-88.

https://doi-org.wvu.idm.oclc.org/10.1080/00336297.2000.10491702

Ford, Biranda. "Approaches to Performance: A Comparison of Music and Acting Students' Concepts of Preparation, Audience and Performance." Music Performance Research 6 (January 2013): 152-69. https://search-ebscohostcom.wvu.idm.oclc.org/login. aspx?direct=true \&db=a9h\&AN=94899246\&site=ehostlive \&scope=site.

Gritten, Anthony. "Dismantling the Demands of Performing." Music Performance Research 9 (January 2019): 162-79. https://search-ebscohostcom.wvu.idm.oclc.org/login. aspx ?direct=true $\& d b=a 9 h \& A N=147663199 \&$ site=ehostlive $\&$ scope $=$ site. 
Güsewell Angelika, Joliat François, and Pascal Terrien. "Professionalized Music Teacher Education: Swiss and French Students' Expectations.” International Journal of Music Education 35, no. 4 (2017): 526-40,

https://journals-sagepub com.wvu.idm.oclc.org/doi/10.1177/0255761416667472

Helding, Lynn. "Master Class Syndrome." Mindful Voice. Journal of Singing 67, no. 1 (2010): 73-8. https://scholar.dickinson.edu/faculty_publications/69/

Holmes, Patricia. "Towards a Conceptual Framework for Resilience Research in Music Training and Performance: A Cross-Discipline Review: 'The Important Thing Is Not to Be Cured, but to Live with One's Ailments.' Albert Camus, The Myth of Sisyphus." Music Performance Research 8 (January 2017): 114-32. https://searchebscohostcom.wvu.idm.oclc.org/login.aspx ?direct $=$ true $\& d b=a 9 h \& A N=123284648 \&$ site $=$ ehost live \&scope=site.

Kamin, Sara, Hugh Richards, and Dave Collins. 2007. "Influences on the Talent Development Process of Non-Classical Musicians: Psychological, Social and Environmental Influences." Music Education Research 9 (3): 449-68. doi:10.1080/14613800701587860.

Kaufman, Brian, and Nell Flanders. 2020. "Leading with Score Study: Changing Priorities in Undergraduate Conducting Curricula.” Music Performance Research 10 (1): 1-20. doi:10.14439/mpr.10.2.

Kennaway, George. "Trills and Trilling: Masks, Dandyism, Historical Performance, and the Self." Music Performance Research 7, no. 1 (January 2015): 47-64. https://searchebscohostcom.wvu.idm.oclc.org/login.aspx?direct=true $\& d b=a 9 h \& A N=109282851 \&$ site $=$ ehostlive \&scope $=$ site.

Kinkeldey, Otto. "The Artist and the Scholar." Papers of the American Musicological Society, 1940, 126-36. http://www.jstor.org/stable/43873095.

Mishra, Jennifer. 2011. "Influence of Strategy on Memorization Efficiency." Music Performance Research 4 (October): 60-71. https://search-ebscohostcom.wvu.idm.oclc.org/login.aspx?direct $=$ true $\& d b=a 9 h \& A N=67338129 \&$ site $=$ ehost live $\&$ scope $=$ site.

Mishra, Jennifer, and Barbara Fast. "Practising in the New World: Strategies for Preparing Contemporary Music for First Performance." Music Performance Research 7, no. 1 (January 2015): 65-80. 
https://search-ebscohost-

com.wvu.idm.oclc.org/login.aspx?direct=true \&db=a9h\&AN=109282853\&site=ehostlive \&scope=site.

Rideout, Roger. "The German Model in Music Curricula." College Music Symposium 30, no. 2 (1990): 106-11. http://www.jstor.org/stable/40374047.

Ruyter, Alex de, Martyn Brown, and John Burgess. 2019. "Gig Work and the Fourth Industrial Revolution: Conceptual and Regulatory Challenges." Journal of International Affairs 72 no.1: 37-50.

Wright, David j., Paul S. Holmes, Martin Blain, and Dave Smith. "Preliminary Evidence for Reduced Cortical Activity in Experienced Guitarist Performance Preparation for Simple Scale Playing.” Music Performance Research 5 (2012 Special Issue 2012): 211. https://search-ebscohostcom.wvu.idm.oclc.org/login. aspx?direct=true \&db=a9h\&AN=90596166\&site=ehostlive \&scope=site.

Zhang J.D, Susino M, Schubert E, and McPherson G.E. "The Definition of a Musician in Music Psychology: A Literature Review and the Six-Year Rule." Psychology of Music 48, no. 3 (2020): 389-409. https://doi.org/10.1177/0305735618804038.

Zhukov, Katie. 2009. "Effective Practising: A Research Perspective.” Australian Journal of Music Education, no. 1 (January): 3-12. https://search-ebscohost-

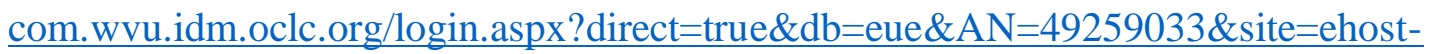
live $\&$ scope $=$ site.

\section{Websites}

AL Kennedy, "Why I hate the myth of the suffering artist," The Guardian, April 2 ${ }^{\text {nd }}, 2012$, https://www.theguardian.com/books/booksblog/2012/apr/02/myth-of-the-sufferingartist.

"How to Forge a Productive Science-Art Collaboration," Springer Nature Advancing Research, https://media.nature.com/original/magazine-assets/d41586-021-003971/d41586-021-00397-1.pdf 


\section{Appendix A}

\section{Sample Syllabi}

All sample syllabi designed for this section only offer guidance to inspire the instructors to elaborate their classes. The grading system, assignments, evaluation processes, points and distribution, schedules, deadlines, external activities, university policies, and further course criteria must be planned and executed considering the institution's needs, its academic calendar, and the vicissitudes of the semesters.

\section{Career Development}

\section{Today's Musician 1: A Professional Guide}

\section{Fall Semester Syllabus}

Course Information:

Instructor: André Januário

Office: Room B 612

Phone: (987) 654-3210

Email: 21stcenturycurriculum@university.edu

Office Hours: by appointment

\section{Course Overview:}

This course is designed to teach graduate music performance students to be prepared for a professional music career and its possibilities. It will help students examine long-term career prospects and devise a plan to integrate artistic career aspirations with supplementary or complementary employment.

\section{Enrollment Requirements:}

Must be a graduate student. However, graduate-level music performance students will have priority to enroll in this course. Undergraduate students interested in enrolling in this course must consult their advisors and instructor to be considered. No further prerequisites.

\section{Required Text:}

- Nytch, Jeffrey. The Entrepreneurial Muse: Inspiring Your Career in Classical Music. New York, NY: Oxford University Press, 2018.

- Beeching, Angela Myles. Beyond Talent: Creating a Successful Career in Music. 2nd ed. New York: Oxford University Press, 2010.

- Additional readings, audio, and video will be assigned during the semester.

- Further Reading: Tim Blanning: The Triumph of Music (selected chapters)

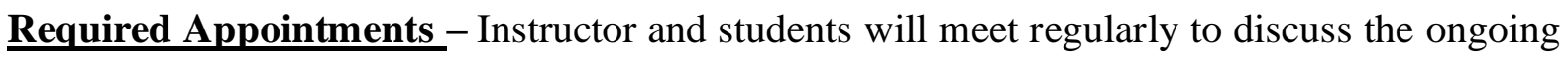
projects. 
Learning objectives: In this course, we will cover the following topics:

- fundamentals of job searching and the creation of employment materials for a wide variety of artistic, non-artistic, and academic employment opportunities;

- entrepreneurship and business planning;

- exploration of nonprofit institutions;

- job interview training.

Learning outcomes: By the end of this course, the student should be able to:

- develop their own professional portfolio and ePortfolio;

- design $\mathrm{CV}$, résumés, and statements;

- formulate their projected professional goals considering three different music career alternatives;

- design an artistic "Five-year" career plan.

\section{Sections and Course Timeline:}

Section 1 (Weeks 1-4): The Professional World of Music

- The Definition of a Musician

- Careers in Music

- The Performer's Career - A Brief Overview

- Building up a music performance career (overview of types of jobs in the US and abroad)

- Building up music scholar career

- Project 1: Project-Based Career Advancement Plan (Due Date: TBD)

Section 2 (Weeks 5-6): Opening doors and "Being Visible"

- Building a Professional Portfolio

- CV versus Résumé

- Job Interviews

- Professional Media (Recordings and Photos)

- Project 2: Website and Social Media - "The New Business Card" (Full Portfolio)

Section 3 (Weeks 7-11): Being a 21 ${ }^{\text {st }}$ Century Musician

- Entrepreneurial Mindset

- Entrepreneurial Actions

- Managing your artistic career (Agencies, Planning, Promoting, Target Audience, etc.)

- Project 3: Building up your 5 Year-Career Plan (Due Date: TBD)

Section 4 (Weeks 12-16): The Music Director Project

- Final Project: Applying the contents and resources explored in Section 3, students will team up (two or three groups) and design, produce, and perform in Chamber Recital Concert. 


\section{Today's Musician 2: A Professional Guide for College Professors}

\section{Fall Semester Syllabus}

Course Information:

Instructor: André Januário

Office: Room B 612

Phone: (987) 654-3210

Email: 21stcenturycurriculum@university.edu

Office Hours: by appointment

\section{Course Overview:}

This course is designed to teach music performance students to be prepared for the professional music career its possibilities. It will help students examine long-term career prospects and devise a plan to integrate artistic career aspirations with supplementary or complementary employment. This second course is designed for performers who aspire to pursue an academic career.

\section{Enrollment Requirements:}

Prerequisites: Today's Musician 1: A Professional Guide. Must be a graduate student. However, graduate-level music performance students will have priority to enroll in this course. Undergraduate students interested in enrolling in this course must consult their advisors and the course's instructor to be considered.

\section{Required Text:}

- Colleen M. Conway and Thomas M. Hodgman: Teaching Music in Higher Education $\left(3^{r d}\right.$ Edition preferably. However, due to price issues, the $2^{\text {nd }}$ edition should be considered. The instructor can approach the topics not covered by the $2^{\text {nd }}$ edition by providing additional materials.)

- Additional readings, audio, and video will be assigned during the semester.

Required Appointments - Instructor and students will meet regularly to discuss the ongoing projects.

Learning objectives: In this course, we will cover the following topics:

- Academia and its organizational structure

- notions of music school administration;

- NASM requirements;

- music performance curricula;

- strategies to build an academic career plan;

- academic counseling and mentorship

- job interview training.

Learning outcomes: By the end of this course, the student should be able to:

- understand the academic career and its processes;

- design a tenure track plan;

- advise and mentor students;

- teamwork and leadership;

- design course descriptions and syllabi;

- create and develop music performance curricula. 


\section{Sections and Course Timeline:}

Section 1 (Weeks 1-4): Understanding the Music Higher Education System

- The Music Performance Curriculum: Its Origins and its Idiosyncrasies

- The Music Performance Higher Education System around the World (Overview)

- Conservatoire Education versus University Education

- "The German Model" and its Influence on Music Performance

- Project 1: Music Performance Curriculum Ideas - Essay (Due date: TBD)

Section 2 (Weeks 5-8): Teaching Music in Higher Education

- Today's Agenda and why it matters in the classroom

- Teaching Applied Music: Approaching Lessons and Studio Classes Accordingly

- Designing Syllabi, Grading Systems, Statements, Evaluations, and Juries

- Mentoring and Advising Students

- Mentoring and Advising International Students (Guest Speaker from the International Students Office)

- NASM Guidelines (An Overview)

- Project 2: Syllabus (with Full Calendar and Statements) (Due date: TBD)

Section 3 (Weeks 8 -11): Music Career in Higher Education - Finding a Job

- The Titles in the Academia: Understanding Job Positions

- Writing a Cover Letters, or Résumé, or CV: Main Differences and Formats

- Letter of Recommendations and Additional Materials

- Interview Processes (Guest Speakers and Mock Interviews)

- Project 3: Job Application Portfolio (Due date: TBD)

Section 4 (Weeks 12-16): The Job

- "The Artist and the Scholar" - Managing Performance and Academic Career

- Project 4: Building up your 5 Year-Career Plan 


\section{Orchestral Entrepreneurship}

\section{Fall Semester Syllabus}

Course Information:

Instructor: André Januário

Office: Room B 612

Phone: (987) 654-3210

Email: 21stcenturycurriculum@university.edu

Office Hours: by appointment

\section{Course Overview:}

This course is designed to equip orchestral students, especially conducting students, with the knowledge and perspective needed to succeed as professional orchestral players in a changing industry. The class covers essential organizational, financial, and programmatic issues affecting orchestras and their entrepreneurial possibilities for the future. Includes guest speakers from the League of American Orchestras, American Federation of Musicians Symphonic Services Division (the Union), and others.

\section{Enrollment Requirements:}

Must be a graduate student. However, graduate-level conducting students will have priority to enroll in this course. Other music major graduate and undergraduate students interested in enrolling in this course must consult their advisors and the course's instructor to be considered.

\section{Required Material:}

- Holoman, D. Kern. The Orchestra: A Very Short Introduction. Oxford: Oxford University Press, 2012.

- Nytch, Jeffrey. The Entrepreneurial Muse: Inspiring Your Career in Classical Music.

New York, NY: Oxford University Press, 2018.

- Additional readings, audio, and video will be assigned during the semester

- Further Reading: Ayer, Julie. More Than Meets the Ear: How Symphony Musicians Made Labor History. Minneapolis: Syren Book, 2005. (Due to price issues related to the printed version, the Kindle Version is strongly recommended).

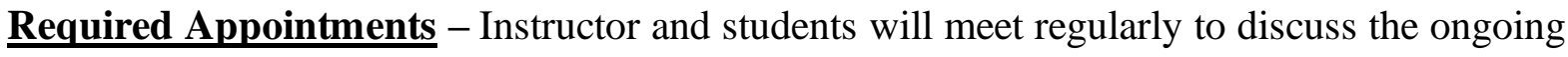
projects.

Learning objectives: In this course, we will cover the following topics:

- American Orchestras: History and Organizational structures;

- notions of orchestra management;

- union, leagues, and associations;

- boards, committees, and sponsors

- audition processes for musicians and conductors;

- repertoire and seasons;

- budget and marketing. 
Learning outcomes: By the end of this course, the student should be able to:

- understand the role of musicians and their conductors in large ensembles, and the developing role of these ensembles in the $21^{\text {st }}$ century;

- develop plans to reach out to the community, sponsors, and other stakeholders;

- critically design a concert season considering the current cultural moment; ${ }^{57}$

- create and be part of an orchestra committee and board of directors-for conductors, understand the agendas of such bodies and productive strategies of interaction;

- coordinate conductor searches - for conductors, understand the range of goals of a conductor search committee.

\section{Sections and Course Timeline:}

Section 1 (Weeks 1-2): The Orchestra - A Very Short Introduction

- The Philharmonic Societies

- Orchestra Categories in the USA

- "The Great Symphonic Boom"

- The Orchestral Musician: Artist or Artisan?

- "The Maestro Myth"

- Project 1: Major Orchestra Concert Seasons: Then and Now - Comparative Charts (Due date: TBD)

\section{Section 2 (Weeks 3 - 7): Orchestral Entrepreneurship}

- Are you in charge? Music Director X Artistic Director X Conductor

- Orchestra Boards, Artistic Directors, and Union: Mode d'Emploi

- Budget, Contracts, and Legal Structures (Guest Speakers from US Major Orchestras)

- Fund-Raising Projects and National Endowment for the Arts (Guest Speaker from the League of American Orchestras)

- Seasons, Venues, and Logistics

- "Full House" - Marketing

- Project 2: Design a "Five Thousand Dollars Concert Season"

\footnotetext{
${ }^{57}$ It is important to clarify here that the study of programming a concert/recital/season is a study in addressing different audiences, the cultural crossroads, and balancing different repertoires. For example, in this third decade of the $21^{\text {st }}$ century, the study of programming has obvious intersections with such concerns as Black Lives Matter, BIPOC repertoire, GLBTQ+ composers. However, it is important to ponder that the current cultural discussions cannot obliterate the considered "standard repertoire." Students need to be exposed to a variety of works to develop a solid understanding of how to design a concert season accordingly.
} 
Section 3 (Weeks 8 -11): Ensemble+Audience $=$ Concert Season

- Orchestra College and its Idiossincrasies

- Amateur Ensembles - How to Bring out their Best

- Pedagogical versus Artistic Repertoire

- Diversity and Inclusivity: The Biased Rep List

- Programming: Types of Concert Seasons

- Project 3: Design a College or Community Orchestra Concert Season considering the topics approached in Section \#3

\section{Section 4 (Weeks 12-16): The Concert}

- Project 4: What's Next for Orchestras? Considering the USA Orchestra

Categories (except college orchestras), design an orchestra concert season pondering the following aspects:

1. Orchestra Category

2. Budget (Grants, NEA, Fund Raisings, Government Support, Donations, etc.)

3. Calendar and Rehearsal times

4. Venue

5. Audience 


\section{Music, Gigs, and Money Seminar}

\section{Fall Semester Syllabus}

Course Information:

Instructor: André Januário

Office: Room B 612

Phone: (987) 654-3210

Email: 21stcenturycurriculum@university.edu

Office Hours: by appointment

This course is designed to cover topics such as taxes, ensemble budget, write national and international grants, create fundraisers, design and present projects to sponsors.

\section{Required Material:}

- Computer

- Kerres, Bernhard, and Bettina Mehne. Be Your Own Manager: A Career Handbook for Classical Musicians. London: Tenaia Management, 2017.

- Additional readings, audio, and video will be assigned during the semester

- Further Reading: Cutler, David. The Savvy Musician: Building a Career, Earning a Living \& Making a Difference. Pittsburgh, PA: Helius Press, 2010.

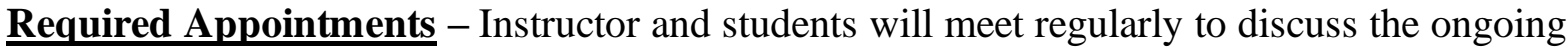
projects.

Learning objectives: In this course, we will cover the following topics:

- types of forms and how to fill them;

- national and international grants: Where to find them? How to apply?;

- types of sponsorships;

- mock project presentations.

Learning outcomes: By the end of this course, the student should be able to:

- fill out forms and taxes accordingly;

- prepare and organize a budget for projects;

- identify and apply for national and international grants;

- prepare and present projects to sponsors such as companies, patrons, and general media.

\section{Sections and Course Timeline:}

Section 1 (Weeks 1-3): Art Music as Product

- Follow the Money: Projects, Grants, and Funds

- Organizational Grants versus Individual Grants

- Donations, Sponsorships, and Partnerships

- Fundraisings and Crowdfundings

- Commissions and Corporate Sponsorships

- Steps for Writing Grants

- Project 1: List up 10 National (or International) Grants or Funds. Write a short essay explaining why you or your project would be a "perfect candidate" to be awarded with their resources. (Due Date: TBD) 
Section 2 (Weeks 4 - 7): Mapping your Audience

- Classical Music Market and its characteristics

- Genres: Symphonic, Solo, Chamber, Choral, Opera, Ballet, Musical

- Subgenres: specific periods/repertoire, types of ensembles, levels, etc.

- The Audience for Classical Music

- Project 2: Choose a grant or fund listed in "Project 1." Design "a mock application" considering the "Steps for Writing Grants" in Section 1.

Section 3 (Weeks 8 - 11): The Office Work

- Introduction to Finance: Revenue, Cost, and Profit

- Types of Forms and Taxes

- Capital Expenditure

- Selling your Project: Writing and Talking about it Commercially

- Project 3: Crowdfunding Project Draft for a Solo or Chamber Recital (Due date: TBD)

Section 4 (Weeks 12 -16): "Due Date"

- Project 4: Crowdfunding Project Presentations to the class and feedback. 


\section{Chamber Music Management}

\section{Fall Semester Syllabus}

Course Information:

Instructor: André Januário

Office: Room B 612

Phone: (987) 654-3210

Email: 21stcenturycurriculum@university.edu

Office Hours: by appointment

This course is designed to teach students how to manage small chamber music groups. How to develop a concert season, programming ideas, concert series, and promotion techniques.

\section{Required Material:}

- Rabideau, Mark. Creating the Revolutionary Artist Entrepreneurship for the $21^{\text {st }}$ Century Musician. Lanham: Rowman \& Littlefield, 2018.

- Additional readings, audio, and video will be assigned during the semester

- Further Reading: Cutler, David. The Savvy Musician: Building a Career, Earning a Living \& Making a Difference. Pittsburgh, PA: Helius Press, 2010.

Required Appointments - Instructor and students will meet regularly to discuss the ongoing projects.

Learning objectives: In this course, we will cover the following topics:

- chamber music in the $21^{\text {st }}$ century: What has changed?;

- marketing: Do and Don'ts;

- repertoires and outfits;

- communication skills;

- coaching methodologies;

- long-term projects.

Learning outcomes: By the end of this course, the student should be able to:

- develop a concert season according to the $21^{\text {st }}$ century expectations;

- manage chamber music ensembles;

- design a long term project for chamber groups;

- initiative and leadership;

- critically design a concert season considering the current cultural moment;

- research repertoire and create concert seasons.

\section{Sections and Course Timeline:}

- Section 1 (Weeks 1-3): Chamber Music: Then and Now

- Traditional Small Chamber Music Ensembles: Origins and Current Tendencies

- String Quartet

- Wind Quintet

- Brass Quintet

- Project 1: Considering all instrumentalists in this course, design a rep list that includes your instrument. Team up and create a " 10 minutes program (approx)." (Due Date: TBD) 
Section 2 (Weeks 4 - 7): Teaching Chamber Music

- Coaching versus Teaching

- How to Prepare a Chamber Music Rehearsal: Part 1 - Musical Aspects

- How to Prepare a Chamber Music Rehearsal: Part 2 - Organizational Aspects

- The "Backward Calendar"

- Rehearsal Techniques - Introduction

- Rehearsal Technique - Guest Speakers "Four Play Clarinets" Members)

- Rehearsal Technique - Guest Speakers “Akropolis Reed Quintet" Members

- Project 2: Design a rehearsal plan for one of the pieces to be performed in the Fall Chamber Music Festival

Section 3 (Weeks 8 - 11): The Chamber Music Fall Festival - “Warm Up”

- Purpose, Agenda, Target Audience, and Repertoire

- Planning a Performance: Part 1 - Organizational Aspects

- Planning a Performance: Part 2 - Artistic Aspects

- Venues, Logistics, and Staff

- Promoting the Event

- Project 3: Marketing Actions

Section 4 (Weeks 12 -16): "The Fall Festival"

- Project 4: After planning and organizing the Chamber Music Fall Festival, students will perform with the group (or groups). 


\section{$\underline{21^{\text {st }} \text { Century Performance Skills }}$}

\section{Practice Strategies for Musicians: Science and Psychology of Music Performance}

\section{Fall Semester Syllabus}

Course Information:

Instructor: André Januário

Office: Room B 612

Phone: (987) 654-3210

Email: 21stcenturycurriculum@university.edu

Office Hours: by appointment

This course is designed to explore different learning techniques when learning or revisiting a music work. The course will investigate how learning works and its various steps, helping students achieve optimal performance levels under the pressure of juries, recitals, competitions, and auditions. Students will learn how to deal with fear and doubts, channel nervousness, focus better, and perform at a high level in stressful situations. As part of the final assignment, all students will perform a short piece in the "Class Recital-Lecture," sharing with the colleagues and audience the techniques and processes applied to learn and improve their performance.

\section{Required Material:}

- Computer

- Berg, Christopher. Practicing Music by Design: Historic Virtuosi on Peak Performance. New York: Routledge, 2019.

- Additional readings, audio, and video will be assigned during the semester

- Further Reading: Helding, Lynn. The Musician's Mind: Teaching, Learning, and Performance in the Age of Brain Science. Lanham, Maryland: Rowman \& Littlefield, 2020.

Required Appointments - Instructor and students will meet regularly to discuss the ongoing projects.

Learning objectives: In this course, we will cover the following topics:

- performance skills profile;

- exercises and mock auditions;

- music cognition;

- deep practice;

- memorization;

- body movement;

- mental rehearsal.

Learning outcomes: By the end of this course, the students should be able to:

- develop practical exercises to manage performance anxiety;

- established strategies and techniques to enhance their practice routines;

- identify pitfalls thoughts and mental strengths;

- understand how music psychology and music cognition help their daily practices;

- develop personal mechanisms to fight back against the negative thoughts during performances;

- develop and demonstrate more confidence on stage. 


\section{Sections and Course Timeline:}

- Section 1 (Weeks 1-3): Knowledge and Skill in Music Performance

- The Definition of a Musician in Music Psychology

- Information and Knowledge

- The "Master Class Syndrome"

- How Learning works

- Difference between Learning and Performance

- Project 1: Learning a New Piece: Write a detailed essay describing how you will prepare a new piece that will be performed at the end of the current semester. Can you identify the "Classic Two Modes of Learning" during this process? (Due Date: TBD)

Section 2 (Weeks 4 - 7): Performance Studies

- Types of Practice: Deliberate, Formal, Informal, Structured, Unstructured

- Motor Learning and Performance

- The Three Rules of Practice

- Mental Work

- Project 2: Select the most challenging passages from one major concerto for your instrument and design "deliberate and structured practice" exercises for them. Include a brief paragraph for each passage explaining how a student should practice the selected excerpts and the reasons/purposes behind the exercises.

Section 3 (Weeks 8 - 11): Practice and Performance Strategies

- How do you Prepare for a Performance in the Long Term and on the Day?

- Practicing and its Stages

- The Four Memorization Strategies

- Performance Anxiety

- Project 3: Recital-Lecture Preparation: By the end of section 3, all students must submit the program notes and an essay describing the processes and techniques used to learn the new piece selected to be performed in the Class Recital-Lecture.

Section 4 (Weeks 12 -16): Class Recital-Lecture

Project 4: Recital Lecture: All students will perform a short piece in the "Class RecitalLecture," sharing with the colleagues and audience the techniques and processes applied to learn and improve their performance. 


\section{Creative Performance Laboratory}

\section{Fall Semester Syllabus}

Course Information:

Instructor: André Januário

Office: Room B 612

Phone: (987) 654-3210

Email: 21stcenturycurriculum@university.edu

Office Hours: by appointment

In this course, students will be required to create and video-record three different interpretative versions of the pieces or method books they will be working on during the semester. The instructor will guide the students in approaching different music styles and genres and helping them to design a program of studies to develop their projects. All students must bring their instruments for this class. All interpretative versions must be upload to the online folder in the system.

\section{Required Material:}

- Computer

- Klickstein, Gerald. The Musician's Way: A Guide to Practice, Performance, and Wellness. Oxford: Oxford University Press, 2009.

- Additional readings, audio, and video will be assigned during the semester

Required Appointments - Instructor and students will meet regularly to discuss the ongoing projects.

Learning objectives: In this course, we will cover the following topics:

- how to define an artist;

- creativity and its processes;

- styles in classical music: then and now;

- musical text and its context;

- organology: instruments and their limitations.

Learning outcomes: By the end of this course, the students should be able to:

- investigate and create scholarly versions of their repertoire;

- understand the current role of the artist and how it differs from former models;

- explain different ways to understand creativity;

- discuss and demonstrate initiative and leadership;

- understand and implement teamwork and communication;

- develop and perform a unique interpretation of a piece of music.

\section{Sections and Course Timeline:}

- Section 1 (Weeks 1-4): The Role of the Performer

- Why Should Performers Study Performance?

- The Paradox of Musical Description

- To Express and to Be Expressive

- Performance Lab ${ }^{58}$

\footnotetext{
${ }^{58}$ Performance Lab: In this specific class (or moment of the class), students will perform their pieces. Instructors are free to organize the format and schedule. It might happen in the last 30 minutes of each class. Or, it might happen once per week, or every two weeks.
} 
- Project 1: Submit the pieces to be worked on during the semester (Due Date: TBD)

Section 2 (Weeks 5 - 9): The Performing Artist

- The Performer: Reader or Interpret? (Roundtable)

- Performance Practices: Then and Now

- Performance Lab

- Project 2: Submit the first video recording (first version), followed by an essay explaining all artistic decisions related to dynamics, phrasing, tempi, articulations, timbre, and more conclusions. (Due Date: TBD)

Section 3 (Weeks 10 - 13): "Performance Mode On"

- Defining and Fostering Creativity

- What Artists Do? Are Performers Creative Beings? (Roundtable)

- Performance Lab

- Project 3: Submit the second video recording. This second version must offer substantial differences from the first version. An essay explaining all artistic decisions must be submitted. (Due Date: TBD)

Section 4 (Weeks 14 -16): Final Recital

- Performance Lab

Project 4: After reflecting on all final artistic decisions, students will perform a "Final Version" of the piece in an in-class recital's last week of classes. The student must record the performance, and a final essay must be uploaded explaining the reasons for the final artistic decisions. 


\section{The Digital Performer}

\section{Fall Semester Syllabus}

Course Information:

Instructor: André Januário

Office: Room B 612

Phone: (987) 654-3210

Email: 21stcenturycurriculum@university.edu

Office Hours: by appointment

This course is designed to introduce basic skills demanded on online teaching and performance. Students will be become technically familiarized with music notation software, recording techniques, popular video and audio platforms, such as Zoom, YouTube, Skype, and social media, and learn how to explore all its resources technically. The final assignment will require an online recital.

\section{Required Material:}

- Computer

- Smartphone or Tablet running the most recent version

- Readings, audio, and video will be assigned during the semester

Learning objectives: In this course, we will cover the following topics:

- types of microphone and its adjustments;

- recording devices setup;

- lighting;

- live stream platform and software;

- social media rules;

- online performances and monetization;

- how music apps can improve and enhance our daily practice;

- how each app and software are designed and their goals.

Learning outcomes: By the end of this course, the student should be able to:

- use technically video platforms and social media and its resources ${ }^{59}$;

- setup and adjust teleconferencing software and streaming platforms;

- create and manage online events and different streaming services;

- create professional-looking scores for many ensembles;

- turn manuscript scores into digital scores for small and large orchestras;

- edit and extract parts from a score in a proper format;

- create simulated performances using MIDI;

- demonstrate an appropriate level of media literacy;

- demonstrate an appropriate level of technology literacy.

\footnotetext{
${ }^{59}$ It includes software, gadgets, and devices system requirements and its compatibility with the platforms and social media to be used in this course.
} 


\section{Sections and Course Timeline:}

Section 1 (Weeks 1-3): Music apps and software for performers ${ }^{60}$

- Types of Apps: Productivity apps, "Practicing Room apps," Sports Video Analysis apps.

- Incorporating Apps to the Practice Routine and Teaching.

- Music Notation Softwares ${ }^{61}$ (A brief introduction and basic functionalities)

- Project 1: Design a "Practice Routine Schedule" using at least three apps analyzed in this section. Besides the main functionality, include at least two extra functionalities that the apps can offer. (Due date: TBD)

\section{Section 2 (Weeks 4-7): Recording Techniques for Performers}

- Sound and Video Recording: Apps, Video and Sound Software (An introduction and basic functionalities)

- Pre-production

- Room Environment

- Interfaces (Brief introduction and basic functionalities)

- Comparison of Different Microphone Positions for Orchestra Instruments

- Types of Microphones and Set up (A brief introduction)

- Professional Cellphone and Tablet Recordings (Things to consider)

- Project 2: A "5 minutes Professional Video Recording" (Including edition) (Due date: TBD)

Section 3 (Weeks 8 -11): Virtual "Teaching-Performance" and its Techniques

- Communications Technology in Education

- Most Used Platforms and its Basic Functionalities

- Social Media for Musicians (formats and technical requirements)

- Set up processes for better teaching and online performance

- Project 3: Online Recital Project Prospectus (Due date: TBD)

Section 4 (Weeks 12-16): Online Recital

- Project 4: Post a "20 minutes Online Recital" on social media (previously informed in Project 3).

\footnotetext{
${ }^{60}$ Some apps might not offer a free version or free trial. In this case, apps with free version should be prioritized. The same might happen with music notation software. In this case, unless the institution is able to offer a free subscription for the students, programs with free, or with a free version, should be prioritized.
} 


\section{Recital-Spectacle Laboratory}

\section{Fall Semester Syllabus}

Course Information:

Instructor: André Januário

Office: Room B 612

Phone: (987) 654-3210

Email: 21stcenturycurriculum@university.edu

Office Hours: by appointment

This class will stimulate music performance students to elaborate recitals in unconventional formats. Students will collaborate with creative arts, acting, production, journalism, and marketing graduate students to elaborate and develop innovative ways to prepare, perform, and promote their concerts. Guided by a team of instructors from different fields, students will explore the goals mentioned above and develop strategies to reach out and create connections between the audience and students.

\section{Required Material}

- Readings, audio, and video will be assigned during the semester

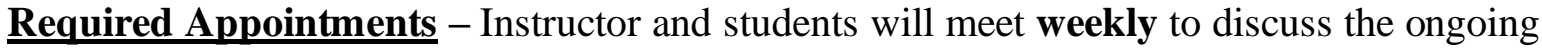
projects.

Learning objectives: In this course, we will cover the following topics:

- beyond the music: recital's goals;

- teamwork skills;

- audience and repertoire: strategies to engage the audience;

- outfits and venues.

Learning outcomes: By the end of this course, the students should be able to:

- identify current best practices for reaching out to their audience;

- create innovative concert programs;

- understand all basic steps in music production;

- understand and demonstrate basic principles of effective communication;

- understand and demonstrate basic principles of effective collaboration;

- understand and demonstrate basic principles of effective social skills;

- demonstrate an artistic stage presence.

\section{Sections and Course Timeline:}

- Section 1 (Weeks 1-3): The Project

- Defining and Designing the Project (Target audience, ideas, venue, team, etc.)

- Reaching out Partners

- "Backward Calendar"

- Feedback

- Final Analysis

- Project 1: Submit the Prospectus Draft (Due Date: $3^{\text {rd }}$ week) 
Section 2 (Weeks 4 - 6): Assembling the Team

- Project Review (if necessary)

- Meeting the Team and Planning the Actions

- Potential Venues and Dates List (Considering the Semester Schedule)

- First Spectacle Draft

- Project 2: Submit the Updated Prospectus, including all names and possible modifications. (Due Date: $6^{\text {th }}$ week)

Section 3 (Weeks 7 - 11): Meetings, Confirmations, Rehearsals, and Marketing Actions

- The venue must be scheduled and confirmed by the end of the $7^{\text {th }}$ week of classes.

- Flyers and Invitations - First Draft ( $\mathbf{8}^{\text {th }}$ week $)$

- All rehearsals must be video recorded to be analyzed by the instructors involved in the project. Feedback will be provided during the weekly meetings.

- Project 3: Submit Updated Prospectus (if necessary). Submit the official flyers

Section 4 (Weeks 12 -16): The Spectacle

- Project 4: Reserved for performances. All performances MUST be video recorded. In addition, all students must submit an essay describing the process to create and perform the project, including a reflection on how this project helped the student artistically. 


\section{Performance and Wellness}

\section{Fall Semester Syllabus}

Course Information:

Instructor: André Januário

Office: Room B 612

Phone: (987) 654-3210

Email: 21stcenturycurriculum@university.edu

Office Hours: by appointment

This course is designed to increase the awareness of the need for physical and mental health in the performance career. Although most of the injuries related to music career might be preventable, we can still observe a significant number of music students and professionals who cope with health issues associated with physical overuse, mental fatigue, and performance anxiety. This course intends to offer tools to develop and cultivate healthy practicing and performance habits, thus helping to prevent life-changing injuries.

\section{Required Material}

- Readings, audio, and video will be assigned during the semester

\section{Learning objectives:}

- develop awareness of a healthy practice routine;

- understand how the body and mind work and prevent injuries;

- develop and improve teaching skills to help future students;

- foster the debate on musician's health and wellness.

\section{Learning outcomes:}

- understand the importance of a healthy music career;

- develop a better understanding of how the body works and the value of respecting its limits;

- demonstrate critical thinking on High-Performance concepts.

\section{$\underline{\text { Sections and Course Timeline: }}$}

- Section 1 (Weeks 1-2): Kinesiology

- How the body works (Guest Speaker from Physical Therapy Program)

- Anatomy and Ergonomic

- Project 1: Roundtable - Bring and share two articles discussing ergonomic related to your instrument for the class. 
Section 2 (Weeks 4 - 8): Healthy Routine

- Identifying the warning signs

- Injury-Prevention

- Rethinking Posture (Guest from Therapeutic and Well-Being Program)

- How to design a healthy practice routine

- "Alexander's Civil War" - Alexander Technique (Concepts)

- Alexander Technique Session (No instrument)

- Alexander Technique Session (With instrument)

- Project 2: Roundtable - "Practicing Room" habits that might compromise our health.

Section 3 (Weeks 9 - 12): The Mind

- The Musician's Mind

- The Idea of "High Performance" (Guest Speaker from Sport Psychology Program)

- Performance Anxiety

- Project 3: Roundtable - The Myth of the Suffering Artist

Section 4 (Weeks 12 -16): The Sound

- Hearing Conservation

- Project 4: Last Roundtable - Building Up a Health Career in Music

Performance 


\section{Appendix B}

Core Curricula from the institutions included in this paper

The Juilliard School - Master's Degree Level ${ }^{62}$

\section{Qualifying Requirements:}

1. Theory and Analysis

2. Ear Training I, II

3. Piano I, II

4. Music History

\section{First Year}

\section{Major Studies}

- Instrument 12 credits

- Departmental Seminar (as required) 0 credit

- Annual Jury 0 credit

\section{Performance Ensembles}

See Special Notes (below)

- Orchestra (PFENS L500-0) 4 credits

- Orchestral Repertory (PFENS R500-0) 4 credits

- Chamber Music (CMENS 500-0) 4 credits

\section{Graduate Courses*}

- GRMUS H600; T600; 600-0 (as advised) 8 credits

62 https://catalog.juilliard.edu/preview_program.php?catoid=47\&poid=4293\&returnto=5297 


\section{Second Year}

Major Studies

- Instrument 12 credits

- Graduation Jury 0 credit

- Recital 2 credits

Performance Ensembles

See Special Notes (below)

- Orchestra (PFENS L500-0) 4 credits

- Chamber Music (CMENS 500-0) 4 credits

Graduate Courses*

- GRMUS H600, T600, 600-0 (as advised) 8 credits 


\section{$\underline{\text { Berklee College of Music }}{ }^{63}$}

Major Requirements

Academics

Electives

Proficiency Requirement

M.M. in Woodwind Performance

2-Year Program (34 credits)

\begin{tabular}{llc|llc}
\hline YEAR 1 & & & & \\
\hline Fall & & Credits & Number & Title & Credits \\
Number & Title & 3.0 & M-AP 0009 & Applied Lesson & 3.0 \\
M-AP 0009 & Applied Lesson & 1.0 & M-EN 0069 & Instrumental Ensemble & 1.0 \\
M-EN 0069 & Instrumental Ensemble & 1.0 & M-ST 0209 & Performance Seminar: Woodwinds & 1.0 \\
M-ST 0209 & Performance Seminar: Woodwinds & 1.0 & & & \\
M-LT 5103 & Writing About Music & 6.0 & & & 5.0 \\
& & & & & \\
\hline
\end{tabular}

\begin{tabular}{llc}
\hline YEAR 1 or 2 & & \\
\hline Fall or Spring & & Credits \\
\hline Number & Title & 1.0 \\
M-EN 0079 & Chamber Music & 1.0 \\
M-EN 0079 & Chamber Music & 1.0 \\
M-LT 5104 & Communicating About Music & 1.0 \\
xxxxx & Elective (any) & 1.0 \\
xxxxx & Elective (any) & 5.0 \\
& &
\end{tabular}

\begin{tabular}{llc|llc}
\hline YEAR 1 or 2 & & & \\
Fall & & Credits & Number & Title & \\
Number & Title & 1.0 & M-PD 0802 & Pedagogy 2: Woodwinds & Credits \\
M-PD 0801 & Pedagogy 1:Woodwinds & 1.0 & & & 1.0 \\
& & & & 1.0 \\
\hline
\end{tabular}

\begin{tabular}{llc|llc}
\hline YEAR 2 & & \multicolumn{2}{l}{ Spring } & & \\
\hline Fall & & Credits & Number & Title & Credits \\
Number & Title & 3.0 & M-AP 0009 & Applied Lesson & 3.0 \\
M-AP 0009 & Applied Lesson & 1.0 & M-EN 0069 & Instrumental Ensemble & 1.0 \\
M-EN 0069 & Instrumental Ensemble & 1.0 & M-ST 0209 & Performance Seminar: Woodwinds & 1.0 \\
M-ST 0209 & Performance Seminar: Woodwinds & & M-SK 0009 & Recital & 0.0 \\
& & & M-EX 6001 & Oral Comprehensive Exam & 0.0 \\
& & 5.0 & & & 5.0 \\
\hline
\end{tabular}
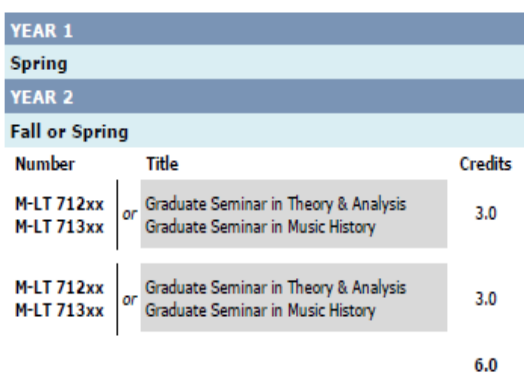

\begin{tabular}{|c|c|c|}
\hline \multicolumn{3}{|c|}{ Proficiency Requirements } \\
\hline Number & Title & Credits \\
\hline M-EX 5101 & Music History 1 Proficiency Exam & 0 \\
\hline M-LT 8101 & or Music History Review 1 & 1.0 \\
\hline $\begin{array}{l}\text { M-EX } 5102 \\
\text { M-LT } 8102\end{array}$ & or Music History 2 Proficiency Exam & 0 \\
\hline $\mathrm{MH}=18102$ & & 1.0 \\
\hline M-EX 5105 & or Ear Training Proficiency Exam & 0 \\
\hline M-SK 8101 & or Remedial Ear Training & 1.0 \\
\hline M-EX 5102 & or Harmony Proficiency Exam & 0 \\
\hline M-SK 8102 & of Remedial Harmony & 1.0 \\
\hline & & 0.0 \\
\hline & & to \\
\hline & & 4.0 \\
\hline
\end{tabular}

${ }^{63}$ https://bostonconservatory.berklee.edu/sites/default/files/d7/bcb/MM\%20Woodwind.pdf 
$\underline{\text { New England Conservatory - Master's Degree Level }}{ }^{64}$

WOODWINDS

Flute, Oboe, Clarinet, Bassoon, Saxophone

CREDITS

Studio*

WW 500

Ensemble

ORCH ENS

Orchestral Repertoire Class** 1

Chamber Music $\ldots 2$

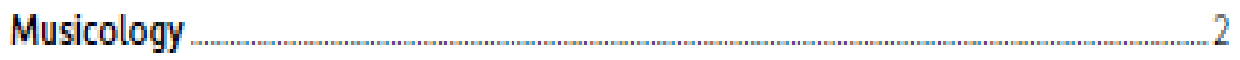

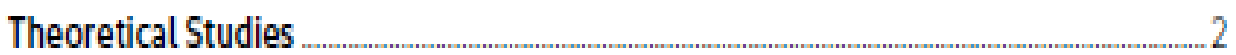

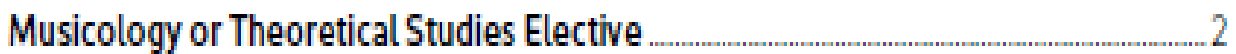

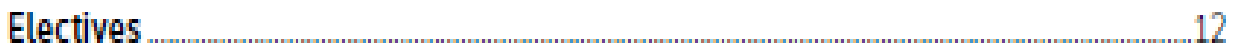

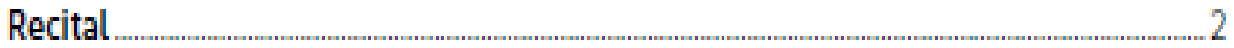

WW 699

Total Credits.

* Saxophone majors only. up to 4 hours of applied study in the jazz area may be substituted after one semester and before the final semester of study with approval from the major teacher and the Jazz Studies department chair

*Saxophone majors only will rep lace the orchestral repertoire requirement with any elective redit

Additional Requirements

1) Promotional at the end of the first year (WW595)

2) Pre-recital in second year

NEC Academic Catalog : 2020/2021

${ }^{64}$ NEC Academic Catalog: https://necmusic.edu/sites/default/files/documents/2020-

2021\%20Academic\%20Catalog_0.pdf 


\section{Yale School of Music ${ }^{65}$}

Master of Music

Special Requirements

All students present a public degree recital in the final year of study; certain departments require a recital in each year of residence. All students must complete four nonperformance electives at the rate of one per term.

Course Requirements

ORCHESTRAL INSTRUMENTS

\begin{tabular}{l|r}
\hline COURSE & CREDITS \\
\hline Yale Philharmonia/New Music New Haven & 8 \\
Chamber Music & 8 \\
Seminar in the Major & 8 \\
Individual Instruction & 16 \\
Group A & minimum of 4 \\
Group B & minimum of 4 \\
\hline TOTAL & 72 \\
\hline
\end{tabular}

Master of Musical Arts

Special Requirements

All students present a public degree recital during each year of residence in the program, one of which must include a lecture component. The number of electives varies according to the requirements of the departments. Some M.M.A. students may be required by their departments to enroll in specific classes. All students must complete four nonperformance electives at the rate of one per term.

Course Requirements

\begin{tabular}{l|r|r}
\hline COURSE & $\begin{array}{r}\text { CREDITS INTERNAL } \\
\text { CANDIDATES }\end{array}$ & $\begin{array}{r}\text { CREDITS EXTERNAL } \\
\text { CANDIDATES }\end{array}$ \\
\hline Individual Instruction & 8 & 16 \\
Chamber Music (where applicable) & 4 & 8 \\
Yale Philharmonia (where applicable) & 4 & 8 \\
Instrumental Seminar (where applicable) & - & 8 \\
Electives & 16 & 24 \\
\hline TOTAL & 32 & 64
\end{tabular}

${ }^{65}$ https://bulletin.yale.edu/sites/default/files/school-of-music-2018-2019.pdf 


\section{$\underline{\text { Manhattan School of Music }}{ }^{66}$}

\section{MASTER OF MUSIC/WOODWIND MAYOR}

FLUTE, OBOE, CLARINET, AND BASSOON

\begin{tabular}{|c|c|c|c|c|}
\hline SUGGESTED DISTRIBUTION BY YEAR AND SEMESTER & \multicolumn{2}{|c|}{1} & \multicolumn{2}{|c|}{2} \\
\hline Major Lessons & 5 & 5 & 5 & 5 \\
\hline Reed/Flute Lab WW2151-2152 & 2 & 2 & 2 & 2 \\
\hline Music History Electives MH1000-2999 & 3 & 3 & & \\
\hline Graduate Theory Electives TH2000-2999 & & & 2 & 2 \\
\hline Graduate Electives & 2 & & 3 & 3 \\
\hline Large Performing Ensemble ${ }^{\star *}$ LP1500 & 1 & 1 & 1 & 1 \\
\hline Chamber Music ${ }^{\star *}$ SP1500 & 1 & 1 & 1 & 1 \\
\hline Concert Attendance CA1000 & 0 & 0 & & \\
\hline Jury & & 0 & & 0 \\
\hline Graduation Recital & & & & 0 \\
\hline TOTAL: 54 & 14 & 12 & 14 & 14 \\
\hline
\end{tabular}

\begin{tabular}{lcccc} 
TOTAL: 54 & 14 & 12 & 14 & 14 \\
\hline "All woodwind players must participate in large ensembles for 4 semesters as assigned by tbe Ensembles Office; in addition, 4 semesters of
\end{tabular}

chamber music must be completed as assigned by the Ensembles Office.

*** Saxopbone majors are required to participate in the repertoire and performance class each semester enrolled, tbus requiring tbese students to register for additional credits eacb semester.

\section{MASTER OF MUSIC/WOODWIND MAFOR}

CLASSICAL SAXOPHONE ONLY

\begin{tabular}{|c|c|c|c|c|}
\hline SUGGESTED DISTRIBUTION BY YEAR AND SEMESTER & & & & \\
\hline Major Lessons & 5 & 5 & 5 & 5 \\
\hline Music History Electives MH1000-2999 & 3 & 3 & & \\
\hline Graduate Theory Electives TH2000-2999 & & & 2 & 2 \\
\hline Graduate Electives & 2 & & 3 & 3 \\
\hline Large Performing Ensemble ${ }^{* *}$ LP1500 & 1 & 1 & 1 & 1 \\
\hline Chamber Music ** SP1500 & 1 & 1 & 1 & 1 \\
\hline Graduate Sax Repetoire Class SX2200*** & 2 & 2 & 2 & 2 \\
\hline Concert Attendance CA1000 & 0 & 0 & & \\
\hline Jury & & 0 & & 0 \\
\hline Graduation Recital & & & & 0 \\
\hline TOTAL: 54 & 14 & 12 & 14 & 14 \\
\hline
\end{tabular}

"All woodwind players must participate in large ensembles for 4 semesters as assigned by the Ensembles Office; in addition, 4 semesters of chamber music must be completed as assigned by the Ensembles Office.

*** Saxophone majors are required to participate in the repertoire and performance class each semester enrolled, thus requiring these students to register for additional credits eacb semester.

\section{PREREQUISITES}

Graduate Theory TH0800, 2883

Aural Skills AS0861-0862

Required Piano RP0121-0122

${ }^{66}$ https://3fv92513fnvf2m1ou93dy4td-wpengine.netdna-ssl.com/wp-content/uploads/2021/02/20-21-CourseCatalog-Feb-19-2021-Update.pdf 


\section{Appendix C}

The National Association of Schools of Music (NASM) was founded in 1924 to secure a better understanding among institutions of higher education engaged in work in music. The association helped to establish a more uniform method of granting credit; and of setting minimum standards for the granting of degrees and other credentials. NASM has been designated by the U.S. Department of Education as the agency responsible for accrediting free-standing institutions that offer music and music-related programs (both degree- and nondegree-granting), including those offered via distance education. ${ }^{67}$

According to NASM, Graduate Program in Music in the U.S. should be organized as follows:

GRADUATE PROGRAMS IN MUSIC ${ }^{68}$

\section{A. FUndAMENTAL PURPOSES AND PRINCIPLES}

1. PURPOSES. EACH INSTITUTION IS RESPONSIBLE FOR DEVELOPING AND DEFINING THE SPECIFIC PURPOSES OF ITS OVERALL GRADUATE PROGRAM IN MUSIC AND OF EACH GRADUATE DEGREE PROGRAM IT OFFERS.

2. RELATIONSHIPS: PURPOSES, CONTENT, AND REQUIREMENTS

A. FOR EACH GRADUATE PROGRAM OFFERED, THERE MUST BE LOGICAL AND FUNCTIONING RELATIONSHIPS AMONG THE PURPOSES, STRUCTURE, AND CONTENT. FOR EACH PROGRAM, THIS INCLUDES DECISIONS ABOUT:

(1) SPECIalization(s).

(2) THE RELATIONSHIPS BETWEEN THE SPECIALIZATION(S) AND MUSIC OR OTHER MUSIC-RELATED DISCIPLINES, OTHER FIELDS OF STUDY, AND MUSIC OR OTHER PROFESSIONS.

(3) REQUIREMENTS IN SUCH AREAS AS COMPOSITION AND PERFORMANCE, RESEARCH, SCHOLARSHIP, PREPARATION FOR TEACHING IN TERMS OF (A) THE SPECIALIZATION, (B) SUPPORT FOR THE SPECIALIZATIONS, AND (C) BREADTH OF COMPETENCE.

B. FOR EACH GRADUATE PROGRAM, tHE CURRICULAR STRUCTURE AND tHE REQUIREMENTS FOR ADMISSION, CONTINUATION AND GRADUATION MUST BE CONSISTENT WITH PROGRAM PURPOSES AND CONTENT.

3. MAJOR FIELD(S) AND SUPPORTIVE STUDIES. EACH GRADUATE STUDENT IS EXPECTED TO GAIN IN-DEPTH KNOWLEDGE AND COMPETENCE IN ONE OR MORE FIELDS OF SPECIALIZATION. GRADUATE PROGRAMS INCLUDE REQUIREMENTS AND OPPORTUNITIES FOR STUDIES THAT SUPPORT THE CHOSEN SPECIALIZATION(S).

\footnotetext{
${ }^{67}$ NASM Handbook 2020-21 (page 1)

${ }^{68}$ NASM Handbook 2020-21 (pages 126-129)
} 
A. Professional work in music specializations is Produced through Creative endeavor, inquiry, and INVESTIGATION. EACH TYPE OF WORK AND EACH INDIVIDUAL WORK EXHIBITS SPECIFIC INTENT, CONTENT, METHODOLOGY, AND PRODUCT. INDIVIDUAL OR GROUP DECISIONS ABOUT THESE FOUR ELEMENTS SHAPE THE WAYS THAT CREATIVITY, INQUIRY, AND INVESTIGATION ARE USED TO PRODUCE WORK IN VARIOUS ARTISTIC, SCHOLARLY, PEDAGOGICAL, OR OTHER SPECIALIZATIONS. COMPETENCY TO PRACTICE IN ONE OR MORE FIELDS OF SPECIALIZATION INCLUDES THE ABILITY TO CONDUCT THE TYPES OF CREATIVE WORK, INQUIRY, AND INVESTIGATION NORMALLYASSOCIATED WITH THE SPECIALIZATION(S) CHOSEN.

\section{B. THESE TYPES INCLUDE, BUT ARE NOT LIMITED TO:}

(1) WORK IN COMPOSITION, PERFORMANCE, OR PRODUCTION THAT RESULTS IN CONTRIBUTIONS TO THE BODY OF KNOWLEDGE AND PRACTICE IN MUSIC.

(2) THE DEVELOPMENT AND APPLICATION OR INCORPORATION OF VARIOUS TYPES OF INQUIRY AND INVESTIGATION, INCLUDING FORMAL RESEARCH OR SCHOLARSHIP THE MUSICIAN WISHES TO USE IN THE COMPOSITION, PERFORMANCE, OR PRODUCTION OF A WORK OF MUSIC.

(3) RESEARCH AND SCHOLARSHIP AS DEFINED AND PRACTICED BY PROFESSIONAL HUMANISTS, SCIENTISTS, AND SOCIAL SCIENTISTS. IN MUSICOLOGY AND ETHNOMUSICOLOGY, MUSIC THEORY, MUSIC SPECIALIZATION, AND OTHER ACADEMIC SPECIALIZATIONS, THIS INCLUDES, BUT IS NOT LIMITED TO, SUCH AREAS AS MUSIC HISTORY, ANALYSIS, AND CRITICISM; THE RELATIONSHIP OF MUSIC TO INQUIRY IN THE HUMANITIES, THE SCIENCES, AND THE SOCIALSCIENCES; THE INFLUENCES OF MUSIC IN AND ON LARGER SOCIAL, CULTURAL, EDUCATIONAL, ECONOMIC, AND TECHNOLOGICAL CONTEXTS; AND THE NATURE AND APPLICATION OF MUSIC THINKING AND PEDAGOGY.

(4) THE DEVELOPMENT, COMPILATION, AND APPLICATION OR INCORPORATION OF INQUIRY RESULTS, INCLUDING THOSE PRODUCED BY FORMAL RESEARCH AND SCHOLARSHIP, IN DECISIONS ABOUT PEDAGOGY AND TEACHING, APPLICATIONS OF MUSIC THERAPY, AND POLICY-MAKING IN VARIOUS CONTEXTS.

5. Types of Degree Programs. Different specializations and different degree programs Reflect SPeCifiC GOALS WITH RESPECT TO RELATIONSHIPS AMONG FIELDS OF PRACTICE AND APPROACHES TO INQUIRY, INVESTIGATION, AND TO RESEARCH AND SCHOLARSHIP AS PRESENTED ABOVE, WHETHER BROADLY OR NARROWLY DEFINED. THE BASIC DEGREE FRAMEWORKS ARE DESCRIBED BELOW.

A. Practice-Oriented Degrees. TheSe degrees focus on the preparation of ARTISTS, Pedagogues, therapists, OR OTHER MUSIC PROFESSIONALS.

DEGREE TITLES REFLECT LEVEL OF STUDY AND CONTENT, AND NORMALLY INCLUDE MASTER OF MUSIC, MASTER OF ARTS, MASTER OF SCIENCE, DOCTOR OF MUSICAL ARTS, DOCTOR OF MUSIC, AND DOCTOR OF EDUCATION.

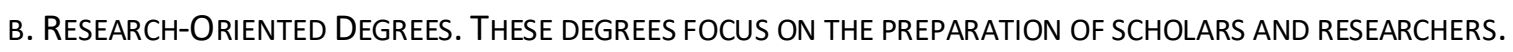

DEGREE TITLES REFLECT LEVEL OF STUDY AND CONTENT AND NORMALLY INCLUDE MASTER OF ARTS, MASTER OF SCIENCE, MASTER OF MUSIC, AND DOCTOR OF PHILOSOPHY.

C. Degrees Combining Research and Practice Orientations. These degrees focus on the simultaneous DEVELOPMENT OF THE ABILITY TO PRODUCE ADVANCED RESEARCH FINDINGS, OFTEN USING THE PRACTICES AND PROTOCOLS OF THE HUMANITIES, SCIENCES, OR SOCIAL SCIENCES, AND THE ABILITY TO UTILIZE, COMBINE, OR INTEGRATE THESE FINDINGS WITH PRACTICE OF THE ARTISTIC, PEDAGOGICAL, THERAPEUTIC, OR OTHER MUSIC-RELATED PROFESSIONS.

DEGREE TITLES REFLECT LEVEL OF STUDY AND CONTENT AND ARE CONSISTENT WITH THE CHARACTER AND REQUIREMENTS OF THE DEGREE RUBRIC CHOSEN. 


\section{BREADTH OF COMPETENCE}

A. COMPONENTS. BREADTH OF COMPETENCE IS CHARACTERIZED BY THE ABILITY TO WORK IN ONE OR MORE FIELDS OF MUSIC WITH A BROAD RANGE OF KNOWLEDGE, SKILLS, AND PERSPECTIVES. AS EXAMPLES, BREADTH OF COMPETENCE INCLUDES THE CAPACITIES TO BE ENGAGED MUSICALLY, ARTISTICALLY, INTELLECTUALLY, AND OPERATIONALLY BEYOND THE MAJOR SPECIALIZATION OR FIELD, CONNECT MUSIC TO OTHER FIELDS AND ISSUES, AND APPLY APPROPRIATE TECHNIQUES AND TECHNOLOGIES TO WORK IN AND ABOUT MUSIC. THE ABILITY TO SPEAK AND WRITE COGENTLY IS CRITICAL FOR ALL PROFESSIONAL MUSICIANS.

B. OPPORTUNITIES AND RELATIONSHIPS. GRADUATE PROGRAMS IN MUSIC SHOULD PROVIDE OPPORTUNITIES FOR INDIVIDUAL STUDENTS TO ENLARGE THEIR BREADTH OF COMPETENCE. THIS INCLUDES OPPORTUNITIES FOR DEEPENING UNDERSTANDING OF THE RELATIONSHIPS AMONG MUSICAL SPECIALIZATIONS SUCH AS PERFORMANCE, HISTORICAL AND THEORETICAL ANALYSIS, COMPOSITION, PEDAGOGY, MUSICOLOGY, AND ETHNOMUSICOLOGY. THE DEVELOPMENT OF BREADTH OF COMPETENCE NORMALLY INCLUDES STUDIES BEYOND THE UNDERGRADUATE LEVEL.

\section{PReparation FOR the PROFESSIONS}

A. Career DeVelopment. Many of those Who earn graduate degrees in MUSiC Will be engaged for SeVeral DECADES IN A VARIETY OF MUSIC AND MUSIC-RELATED PROFESSIONS. STUDENTS SHOULD BE ENCOURAGED TO ACQUIRE THE CAREER DEVELOPMENT AND ENTREPRENEURIAL TECHNIQUES, BECOME AWARE OF THE ATTRIBUTES AND CHARACTERISTICS ASSOCIATED WITH LEADERSHIP, AND DEVELOP CONNECTIONS AND RECORDS OF ACHIEVEMENT NECESSARY TO (1) ADVANCE THEMSELVES CONSISTENT WITH EXPECTATIONS AND PRACTICES IN THEIR AREA OF SPECIALIZATION, AND (2) FULFILL THEIR OWN CAREER OBJECTIVES.

B. TEACHING. MOST OF THOSE WHO ARE IN GRADUATE DEGREES IN MUSIC ARE OR WILL BE ENGAGED IN MUSIC TEACHING OF SOME TYPE DURING THE COURSE OF THEIR PROFESSIONAL CAREERS. INSTITUTIONS ARE THEREFORE STRONGLY ENCOURAGED TO GIVE ATTENTION TO THE PREPARATION OF GRADUATE STUDENTS AS TEACHERS. WHENEVER POSSIBLE, EXPERIENCES SHOULD INCLUDE TEACHING MUSIC TO BOTH MUSIC MAJORS AND NON-MUSIC MAJORS. GRADUATE STUDENTS, PARTICULARLY AT THE DOCTORAL LEVEL, SHOULD HAVE OPPORTUNITIES FOR DIRECT TEACHING EXPERIENCES APPROPRIATE TO THEIR MAJOR AND MINOR AREAS UNDER THE SUPERVISION OF MASTER TEACHERS. AS APPROPRIATE TO PRIMARY AND SECONDARY AREAS OF CONCENTRATION AND TO INDIVIDUAL CAREER OBJECTIVES, PREPARATION FOR TEACHING SHOULD INCLUDE AN INTRODUCTION TO THE PEDAGOGY OF SUBJECT MATTER CONSIDERED FUNDAMENTAL TO CURRICULA FOR UNDERGRADUATE MUSIC MAJORS, INCLUDING COMPOSITION AND IMPROVISATION, MUSIC THEORY AND HISTORY, MUSIC FROM A BREADTH OF CULTURES, TECHNOLOGY, AND PERFORMANCE.

\section{B. RESOURCES AND MUSIC PROGRAM COMPONENTS}

1. RESOURCES MUST BE SUFFICIENT TO SUPPORT THE PURPOSES, GOALS, OBJECTIVES, AND CONTENT OF GRADUATE PROGRAMS AND MUST MEET NASM OPERATIONAL REQUIREMENTS IN THIS REGARD (SEE STANDARDS FOR ACCREDITATION II.). THE RELATIONSHIPS BETWEEN THE ESTABLISHMENT OF OBJECTIVES AND THE DEVELOPMENT OF PROGRAM STRUCTURE AND RESOURCES ARE CRUCIAL TO SUCCESS. THE PROCESS OF ESTABLISHING AND MAINTAINING THESE RELATIONSHIPS SHOULD BE CHARACTERIZED BY THE SAME RIGOROUS PURSUIT OF CREATIVE DEVELOPMENT AND ANALYTICAL EXCELLENCE THAT ARE FUNCTIONS OF GRADUATE STUDY ITSELF.

2. CURRICULAR COMPONENTS OF GRAdUATE PROGRAMS MUST MEet NASM REQUIREMENTS IN STANDARDS fOR ACCREDITATION III. (INCLUDING, BUT NOT LIMITED TO CREDIT AND TIME REQUIREMENTS; TIME ON TASK, CURRICULAR PROPORTIONS, AND COMPETENCIES; FORMS OF INSTRUCTION, REQUIREMENTS, AND ELECTIVES; INDIVIDUAL PROGRAM CONTINUITY; RESIDENCE).

3. THE STANDARDS APPLICABLE TO EACH GRADUATE PROGRAM ARE COMPRISED OF THOSE REFERENCED IN STANDARDS FOR ACCREDITATION X.B.1. AND 2., AS WELL AS THOSE OUTLINED FOR SPECIFIC PROGRAMS THAT FOLLOW. 
4. COMMUNITY. AN INSTITUTION'S OVERALL GRADUATE PROGRAM IN MUSIC REQUIRES A TRADITIONAL AND/OR VIRTUAL COMMUNITY OF STUDENTS AND FACULTY TO PERMIT THE FORMAL AND INFORMAL SHARING OF EXPERIENCE, IDEAS, AND KNOWLEDGE.

5. EXPERIENCES. GRADUATE EDUCATION REQUIRES THE PROVISION OF CERTAIN KINDS OF EXPERIENCES THAT GO BEYOND THOSE TYPICALLY PROVIDED IN UNDERGRADUATE PROGRAMS. THESE INCLUDE OPPORTUNITIES FOR ACTIVE PARTICIPATION IN SMALL SEMINARS AND TUTORIALS, EXTENSIVE INFORMAL CONTACT WITH FACULTY, AND CONSULTATION DURING PREPARATION OF A FINAL PROJECT OVER AN EXTENDED PERIOD OF TIME.

C. General Degree ReQuirements and Procedures

1. CREDITS

A. AT LEAST ONE-HALF OF THE CREDITS REQUIRED FOR GRADUATE DEGREES MUST BE IN COURSES INTENDED FOR GRADUATE STUDENTS ONLY.

B. A SINGLE COURSE THAT CARRIES BOTH AN UNDERGRADUATE AND A GRADUATE DESIGNATION IS NOT CONSIDERED A COURSE INTENDED FOR GRADUATE STUDENTS ONLY.

C. A COURSE MAY ENROLL AN UNDERGRADUATE STUDENT AND MAINTAIN ITS STATUS AS BEING INTENDED FOR GRADUATE STUDENTS ONLY IF, IN THE CONTEXT OF THAT COURSE, THE UNDERGRADUATE STUDENT IS EXPECTED TO MEET THE SAME STANDARDS, DO THE SAME WORK, AND OTHERWISE PERFORM AS A GRADUATE-LEVEL STUDENT.

D. TO OBTAIN GRADUATE CREDIT, STUDENTS ENROLLED IN A SINGLE COURSE THAT CARRIES A SEPARATE UNDERGRADUATE AND GRADUATE DESIGNATION OR NUMBER MUST COMPLETE SPECIFIC PUBLISHED REQUIREMENTS THAT ARE AT A GRADUATE LEVEL. DISTINCTIONS BETWEEN UNDERGRADUATE AND GRADUATE EXPECTATIONS MUST BE DELINEATED FOR SUCH COURSES.

E. ONLY COURSES TAKEN AFTER UNDERGRADUATE COURSES THAT ARE PREREQUISITE TO A GIVEN GRADUATE PROGRAM MAY RECEIVE GRADUATE DEGREE CREDIT IN THAT PROGRAM.

2. ResidenCE. Residence policies are determined by the InStitution. NoRmally, a PeRIOd of CONTINUOUS CONCENTRATED STUDY WITHIN THE GRADUATE COMMUNITY IS REQUIRED. PROGRAMS BASED ON DISTANCE LEARNING, OR WITH A SIGNIFICANT DISTANCE LEARNING COMPONENT, MUST FULFILL THE FUNCTION OF COMMUNITY BY PROVIDING EXPERIENCES THAT PRODUCE INTERACTION AMONG GRADUATE STUDENTS AND FACULTY.

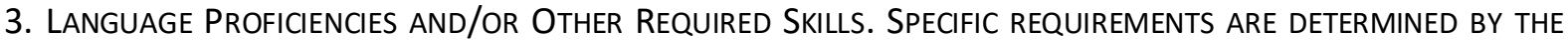
INSTITUTION BASED ON THE OBJECTIVES OF THE PROGRAM.

4. COURSEWORK. INSTITUTIONS DETERMINE COURSEWORK REQUIREMENTS FOR EACH GRADUATE PROGRAM. REQUIREMENTS FOR THE MASTER'S DEGREE ARE USUALLY STATED IN TERMS OF SPECIFIC CREDITS. AT LEVELS ABOVE THE MASTER'S, INSTITUTIONS MAY NOT WISH TO SPECIFY COURSE OR CREDIT REQUIREMENTS, OTHER THAN THE SATISFACTORY COMPLETION OF CERTAIN EXAMINATIONS, RECITALS, COMPOSITIONS, OR A DISSERTATION. WHATEVER THE STRUCTURE OF THESE REQUIREMENTS, THERE SHOULD BE A LOGICAL RELATIONSHIP BETWEEN STUDIES AND EXPERIENCES THAT DEVELOP KNOWLEDGE AND SKILLS, AND THOSE THAT EVALUATE PROGRESS.

5. INDEPENDENT STUDY. PROGRAMS THAT INCLUDE OR ARE BASED UPON INDEPENDENT STUDY MUST MEET APPLICABLE REQUIREMENTS IN STANDARDS FOR ACCREDITATION III.

6. Programs involving Distance learning, Disciplines in Combination, or With a Focus on Electronic Media. Program in these CATEGoRIES MUST MEet APPLICABLE REQUIREMENTS IN STANDARDS FOR ACCREDITATION III.

\section{EVALUATIONS}


A. COMPREHENSIVE REVIEWS. COMPREHENSIVE REVIEWS COVER THE MAJOR FIELD OF STUDY, PARTICULARLY AS DEFINED BY THE DEGREE TITLE, AND ANY OTHER ASSOCIATED OR REQUIRED FIELDS SPECIFIED BY THE INSTITUTION. AT THE COMPLETION OF COURSEWORK OR DURING THE DEVELOPMENT OF PROFICIENCIES, THE FUNCTION OF COMPREHENSIVE REVIEW IS ACHIEVED THROUGH MECHANISMS SUCH AS WRITTEN OR ORAL COMPREHENSIVE EXAMINATIONS, SEMINARS PROVIDING SUMMARY EVALUATION, OR A CUMULATIVE SERIES OF REVIEWS. AT THE MASTER'S LEVEL, SUCCESSFUL COMPLETION OF THIS REVIEW IS A REQUIREMENT FOR GRADUATION. AT THE DOCTORAL LEVEL, SUCCESSFUL COMPLETION OF THIS REVIEW QUALIFIES THE STUDENT FOR DEGREE CANDIDACY.

B. Final EXamination. At the doctoral leVel, the final eXAMINAtion may be given after all other degree REQUIREMENTS HAVE BEEN MET, INCLUDING THE FINAL PROJECT. THIS EXAMINATION MAY BE IN DEFENSE OF A DISSERTATION; IT MAY BE CONCERNED WITH THE MAJOR PERFORMING MEDIUM AND ITS REPERTORY; OR IT MAY BE CONCERNED WITH COMPOSITIONS SUBMITTED FOR THE DEGREE.

8. FINAL PROJECT. FOR DEGREE PROGRAMS IN WHICH A FINAL PROJECT IS REQUIRED, THE FINAL PROJECT IS UNDERTAKEN IN THE AREA(S) OF SPECIALIZATION. AT THE DOCTORAL LEVEL, IT IS EXPECTED TO BE COMPARABLE TO HIGH-LEVEL WORK PRESENTED TO THE PUBLIC BY PROFESSIONALS IN THE FIELD. 


\section{Appendix D}

\section{Courses included in this study}

\section{Macro areas and subjects}

\section{Career Development}

1. Career Development Seminar

2. The Musician as Entrepreneur

3. Breaking Barriers: Classical Music in an Age of Pop

4. Speaking of Music: How to Talk and Write About Music

5. Leadership and Innovation in the Creative Arts

6. Advanced Career Skills for Musicians

7. The Entrepreneurial Musician: Graduate Seminar

8. Entrepreneurial Internship

9. Grant Writing and Fundraising for Artists

10. Music Law 101: Copyright Basics

11. Creating an Audience: Marketing Basics

12. Finance 101: What Musicians Need to Know

13. EM Expo Seminar: The Journey from Thinking to Creating

14. Careers in Music: Innovation and Collaboration for Arts Leadership in the Post-COVID-19 World

15. Orchestral Entrepreneurship

16. Practical Foundations: Entrepreneurial Leadership Skills

17. Community Outreach for Musicians

\section{Music Tech}

1. Introduction to Music Technology

2. Global Influences in Contemporary Music Production

3. Composing for Visual Media

4. Scoring to Picture Workshop

5. Introduction to Interactive Music Technology

6. Advanced Interactive Music Technology

7. From Studio to Stage

8. Introduction to Music Programming in MAX

9. Third Stream Methodology I

10. Third Stream Methodology II

11. Creative Recording Concepts for Musicians

\section{Musicians' health}

1. Alexander Technique for Musicians

2. Adv Alexander Technique for Musicians

3. Body Mapping I

4. Body Mapping II

5. Alexander Technique

6. Advanced Alexander Technique

7. Biomechanics/Ergonomics for Performers 


\section{Performance}

1. Creation, Improvisation \& Technology

2. Performance Enhancement

3. Seminar in Performance

4. Contemporary Improvisation Workshop

5. Performing Musicians and Community Health

6. Preparing the Exit

7. The 21st-Century Pianist: Exploring Performance Strategies and Techniques in Contemporary Music

8. Curricular Practical Training

9. Performance Techniques

10. Woodwind Lab

\section{Pedagogy}

1. The Art of Teaching in the Music Studio

2. Advanced Teaching Techniques

\section{Arts and Society}

1. The Arts and Society

2. Issues and Trends in American Music

3. Eco-Music

4. Music and Social Change

5. Music, Service, and Society

6. Sex and Sensibility in Early Opera

7. Foundations of Critical Inquiry

\section{Creativity}

1. The Creative Musician

\section{Other}

1. Music, Spirit, and Transformation

2. Caribbean Music, Sacred Ecologies, and the Environment 


\section{Bio}

André Januário is an avid orchestral and chamber musician. Among his recent professional activities, he worked as an Adjunct Professor of Bassoon and Introduction to Music at Middle Tennessee State University, where he integrated the Faculty Wind Quintet, directed the Bassoon Ensemble, and co-directed the Double Reed Ensemble at MTSU. Mr. Januário graduated from West Virginia University with a Master of Music degree in Bassoon Performance and additional studies in Orchestral Conducting in 2016. As a DMA student at WVU, he worked as a teaching assistant in instrumental and choral conducting classes. He also had the opportunity to work as a graduate assistant playing in all WVU major instrumental ensembles and the wind graduate quintet. In addition, Mr. Januário has developed a comprehensive career working with school ensembles, church orchestras, choirs, and youth orchestras.

For three seasons, he served as a music director and conductor of the Morgantown Community Orchestra at West Virginia University Community Music Program. Under his baton, the MCO established intense and proactive concert seasons, increasing the audience and creating a solid partnership between the community and the orchestra. Also, ahead of the $\mathrm{MCO}$, he created the "MCO Soloists Series" to help young musicians debut their careers on stage. In addition, he commissioned and premiered orchestral works to promote young composers.

In Brazil, Mr. Januário's first professional orchestral appointment as bassoonist was as assistant principal bassoon of the Theatro Municipal do Rio de Janeiro Symphony Orchestra, one of South America's most distinguished opera and ballet houses, for five seasons. He also served as principal bassoon of the Caxias do Sul Symphony Orchestra (OSUCS) and the Theatro São Pedro Chamber Orchestra in Porto Alegre. As a bassoon teacher, Mr. Januário was a bassoon instructor at the University of Caxias do Sul School of Music, besides his private studio. Additionally, he worked as the music director and conductor of the University of Caxias do Sul Youth Orchestra, as a band director in public schools, and as a church music director.

Mr. Januário began studying bassoon with the world-famous French bassoonist Noël Devos. He went on to study bassoon and orchestral conducting at the Federal University of Rio de Janeiro, where he graduated with a Bachelor of Music in Performance. Among his significant mentors are renowned bassoonists and conductors such as Noël Devos, Aloysio Fagerlande, Fabio Cury, Milan Turkovic, Lynn Hileman, Ernani Aguiar, Ricardo Rocha, André Cardoso, Mitchell Arnold, and Scott Tobias. 